RELATIVE PERFORMANCE OF SOYBEAN GENOTYPES

SELECTED FOR DIVERSE SHORT-DAY

ENVIRONMENTS

BY

PONCIANO PEREZ-GARCIA

A DISSERTATION PRESENTED TO THE GRADUATE COUNCIL OF THE UNIVERSITY OF FLORIDA IN

PARTIAL FULFIIIMENT OF THE REQUIREMENTS

FOR THE DEGREE OF DOCTOR OF PHILOSOPHY

UNIVERSITY OF FLORIDA

1981 
To my wife, Dora Elia

and

sons

Gerardo and Fernando

with love and gratitude 


\section{ACKNOWLEDGEMENTS}

Sincere appreciation and gratitude is expressed to Dr. Kuell Hinson, chairman of the supervisory committee, for his understanding, lasting patience, and support during all phases of the graduate program, research, and preparation of this manuscript. Appreciation is also extended to the other members of the author's committee, Dr. Earl S. Horner, Dr. Charles E. Dean, Dr. William G. Blue, and Dr. Richard D. Berger for reading and giving suggestions which resulted in improvements of the dissertation.

Special thanks are given to graduate student Philip J. d'Almada for his helpful assistance with the statistical analyses.

The author wishes to express his gratitude to Consejo Nacional de Ciencia y Tecnologia (CONACYT) of Mexico for granting the scholarship which enabled him to conduct his studies at the University of Florida. For the facilities in Mexico and for other support, recognition is given to Instituto Nacional de Investigaciones Agricolas (INIA). Gratitude is also expressed to Eduardo Calero at the Instituto Nacional de Investigaciones Agropecuarias (INIAP) for supplying data from Boliche, Ecuador. 
ACKNOWLEDGEMENTS. . . . . . . . . . . . . . . . . .

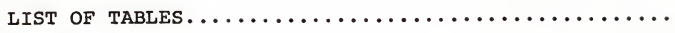

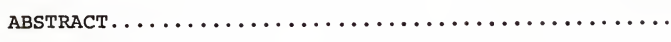

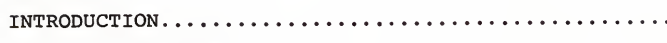

LITERATURE REVIEW......................... 4

MATERIALS AND METHODS.................... 12

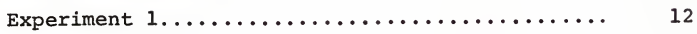

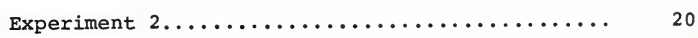

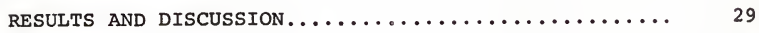

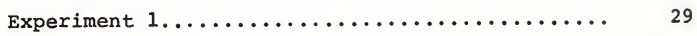

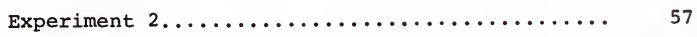

SUMMARY AND CONCLUSIONS................... 83

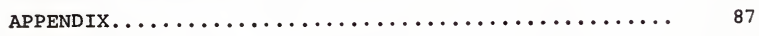

LITERATURE CITED ....................... 114

BIOGRAPHICAL SKETCH.................... 118 
Table

1 Progenitors, generation, number of lines grown and selected at two locations: Gainesville, Florida (USA), and Tancasneque, Tamaulipas

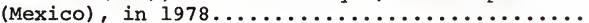

2 Arrangement of the lines selected in 1978 by

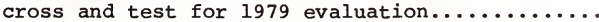

3 Summary of materials and methods for the various tests (Experiment 1 ) by locations and years.....

4 Soybean breeding lines, their parentage and generation composited selected for Test 1978,

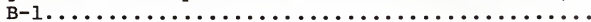

5 Soybean breeding lines, their parentage and generation composited selected for Test 1978,

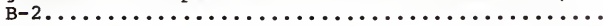

6 Summary of materials and methods for the various tests (Experiment 2) by locations and years....

7 Mean squares for yield of 40 soybean genotypes grown during 1979 at two locations. (Test 1979, A-1, without and with adjusted plot yields at Tancasneque. ).........................

8 Mean yield of 16 soybean genotypes from Test 1979, A-1, which contributed little to the genotype $x$ location interaction by $\mathrm{kg} / \mathrm{ha}$, rank, and as percent of overall test mean..............

9 Mean yield of 14 soybean genotypes from Test 1979, A-1, which contributed most to the genotype $\mathrm{x}$ location interaction in $\mathrm{kg} / \mathrm{ha}$, rank, and as percent of overall test mean.............

10 Mean squares for yield of 24 soybean genotypes grown during 1980 at two locations (Test 1980 , A-3).

11 Mean squares for yield of 24 soybean genotypes grown during 1980 at two locations (Test 1980 ,

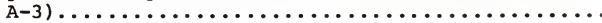

12 Combined analyses for yield of 24 soybean genotypes grown in 1980 at four locations (Test 1980, $\mathrm{A}-3$ ) 
13 Mean squares for yield of 40 soybean genotypes grown during 1979 at two locations (Test 1979,

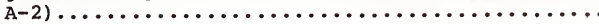

14 Mean yield of 21 soybean genotypes from Test 1979, A-2, which were selected for retesting (in 1980) in $\mathrm{kg} / \mathrm{ha}$, rank, and as percent of overall test mean.......................

15 Mean squares for yield of 24 soybean genotypes grown during 1980 at four locations (Test 1980,

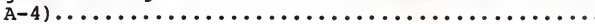

16 Simple correlation coefficients of yield and some agronomic characteristics between

Gainesville and Tancasneque by years and tests

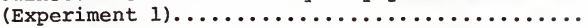

17 Test means and ranges at Gainesville and

Tancasneque for characters used in correlation

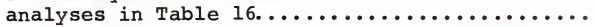

18 Mean squares for yield of 24 and 22 soybean genotypes grown during 1978 at two locations $(1978, \mathrm{~B}-1$ and $1978, \mathrm{~B}-2) \ldots \ldots \ldots \ldots \ldots \ldots \ldots \ldots$

19 Mean yield of 11 and 10 soybean genotypes from Tests $1978, B-1$ and $B-2$ respectively, which contributed little to the genotype $x$ location interaction in $\mathrm{kg} / \mathrm{ha}$, rank, and as percent of

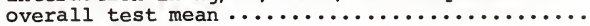

20 Mean yield of 9 and 12 soybean genotypes from Tests $1978, \mathrm{~B}-1$ and $\mathrm{B}-2$ respectively, which contributed most to the genotype $x$ location interaction in $\mathrm{kg} / \mathrm{ha}$, rank, and as percent of

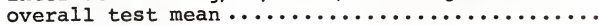

21 Mean squares for yield of 24 soybean genotypes grown during 1979 and 1980 at two locations (Tests $1979, \mathrm{~B}-3$ and $1980, \mathrm{~B}-4) \ldots \ldots \ldots \ldots \ldots \ldots$

22 Mean squares for yield of 24 soybean genotypes grown during two years at two locations.......

23 Mean yield of 24 soybean genotypes grown during 1979 and 1980 at two locations in $\mathrm{kg} / \mathrm{ha}$, rank, and as percent of overall test mean .......... 
24 Simple correlation coefficients of yield and some agronomic characteristics between

Gainesville and Tancasneque by years and tests

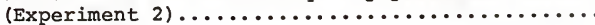

25 Mean squares for yield of 24 soybean genotypes grown during 1979 (Boliche) and 1980 (Boliche

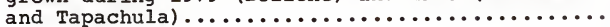

26 Significance and $F$ values for genotypes $x$ environment interactions in 21 combined analyses of 24 soybean genotypes grown at four locations

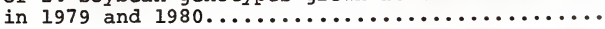

27 Mean yield of 24 soybean genotypes as percent of the test mean and environment, mean and standard deviation.

\section{APPENDIX}

1 Mean yield of 40 soybean genotypes grown during 1979 at two locations in $\mathrm{kg} / \mathrm{ha}$, rank and as percent of overall test mean. (Test 1979, A-1). Duncan's test at .05 level..................

2 Agronomic characteristics of 40 soybean genotypes grown during 1979 at two locations. (Test 1979, A-1).

3 Mean yield of 24 soybean genotypes grown during 1980 at four locations in $\mathrm{kg} / \mathrm{ha}$, rank, and as percent of overall test mean. (Test 1980, A-3).

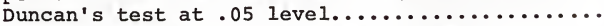

4 Agronomic characteristics of 24 soybean genotypes grown during 1980 at four locations. (Test 1980,

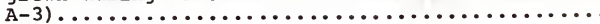

5 Mean yield of 40 soybean genotypes grown during 1979 at two locations in $\mathrm{kg} / \mathrm{ha}$, rank and as percent of overall test mean. (Test 1979, $\mathrm{A}-2)$. Duncan's test at .05 level............ 95

6 Agronomic characteristics of 40 soybean genotypes grown during 1979 at two locations. (Test 1979,

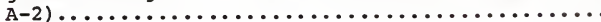


7 Mean yield of 24 soybean genotypes grown during 1980 at four locations in $\mathrm{kg} / \mathrm{ha}$, rank and as percent of overall test mean. (Test $1980, \mathrm{~A}-4$ ).

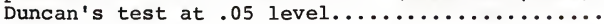

8 Agronomic characteristics of 24 soybean genotypes grown during 1980 at four locations. (Test 1980,

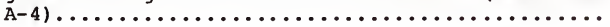

9 Mean yield of 24 soybean genotypes grown during 1978 at two locations in $\mathrm{kg} / \mathrm{ha}$, rank, and as percent of overall test mean. (Test 1978, B-1).

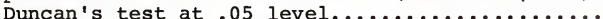

10 Agronomic characteristics of 24 soybean genotypes grown during 1978 at two locations. (Test 1978,

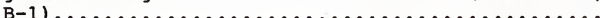

11 Mean yield of 22 soybean genotypes grown during 1978 at two locations in $\mathrm{kg} / \mathrm{ha}$, rank and as percent of overall test mean. (Test 1978, B-2).

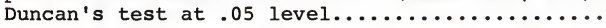

12 Agronomic characteristics of 22 soybean genotypes grown during 1978 at two locations. (Test 1978,

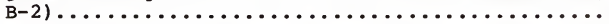

13 Mean yield of 24 soybean genotypes grown during 1979 at three locations in $\mathrm{kg} / \mathrm{ha}$, rank and as percent of overall test mean. (Test 1979, B-3).

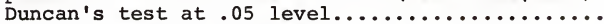

14 Agronomic characteristics of 24 soybean genotypes grown during 1979 at three locations. (Test 1979,

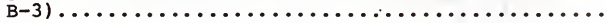

15 Mean yield of 24 soybean genotypes grown during 1980 at four locations in $\mathrm{kg} / \mathrm{ha}$, rank and as percent of overall test mean. (Test $1980, \mathrm{~B}-4$ ).

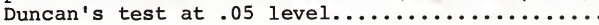

16 Agronomic characteristics of 24 soybean genotypes grown during 1980 at four locations. (Test 1980,

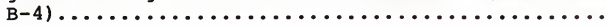


Abstract of Dissertation Presented to the Graduate Council of the University of Florida in Partial Fulfillment of the Requirements for the Degree of Doctor of Philosophy

\title{
RELATIVE PERFORMANCE OF SOYBEAN GENOTYPES SELECTED FOR DIVERSE SHORT-DAY ENVIRONMENTS
}

\author{
By \\ Ponciano Perez-Garcia
}

June 1981

Chairman: Kuell Hinson

Major Department: Agronomy

Soybean [Glycine max (L.) Merrill] cultivars adapted to temperate regions usually perform poorly in tropical

environments. The shorter photoperiods cause reduced growth, early maturity, and low yield. However, later maturing cultivars have good yield potentials in tropical environments. The soybean breeding program at Gainesville, Florida, contained late maturing genotypes potentially well adapted to tropical environments and to mid-July planting in southern U.S. The purpose of this study was to determine the extent to which selection among late maturing genotypes at Gainesville $\left(29^{\circ} 30^{\prime} \mathrm{N}\right.$-latitude) influences performance at Tancasneque, Tamaulipas, Mexico (22० $13^{\prime} \mathrm{N}$-latitude), and to identify developmental characteristics which could be selected at Gainesville to improve performance at lower latitudes. 
Breeding stocks selected were in two developmental stages. For Experiment 1, seeds from 621 individual plants selected in 1977 produced progeny rows at both Gainesville and Tancasneque in 1978. Breeding lines established from rows at each location were evaluated in replicated plots in 1979 and 1980. For Experiment 2, 42 lines which had survived preliminary yield tests at Gainesville were selected and evaluated similarly in 1979-1980. Selected lines were near the height and maturity of Jupiter, a cultivar well adapted to tropical environments and to late plantings at Gainesville. Evaluation locations were expanded to include Boliche, Ecuador ( $\left.{ }^{\circ} 15^{\prime} \mathrm{s}-l a t i t u d e\right)$, in 1979 and 1980, and Tapachula, Chiapas, Mexico, in 1980 (14 59' N-latitude).

Growth characteristics of nearly all selected lines were acceptable for cultivars in all tropical environments. Seed yields in tropical environments often equalled or exceeded seed yields in mid-July plantings at Gainesville. In nearly all environments genotypes in both experiments differed significantly in yield.

In Experiment 1, few genotype $\mathrm{x}$ environment interactions were significant. These results and comparisons of yield means indicated that selection for yield at Gainesville would tend to improve the yield potential for tropical environments. Significant positive correlations between seed yield at Tancasneque and plant height and maturity at Gainesville indicate that selecting the taller, later 
maturing plant types at Gainesville would further improve the yield potential for tropical environments.

In Experiment 2, nearly all genotype $x$ environment interactions were significant. These significant interactions included genotype $\mathrm{x}$ year interactions at Tancasneque and Boliche, but not at Gainesville. Results from Experiment 2 indicate generally poor agreement among environments in relative yield. The Gainesville environments tended to be among the best predictors of overall yield. However, examination of yield means show that very rigid selection for yield at Gainesville would have eliminated one genotype which yielded very well in nearly all tropical environments.

The overall results indicate that selection at Gainesville for plant types adapted to tropical environments can be very effective, that modest selection for yield will likely be beneficial, but that rigid selection for yield should be avoided. 


\section{INTRODUCTION}

Yield potential of soybean [GIycine max (L.) Merrill] in tropical areas is similar to that in temperate regions (Whigham et al., 1978). However, cultivars adapted to temperate regions usually give unsatisfactory results in tropical regions. Plants flower within 25 to 30 days after emergence, mature when they are less than 100 days old, and produce poor quality seed. The early flowering results in short plants with seed produced too close to the ground for efficient mechanical harvesting. In southern U.S., adapted determinate cultivars usually flower in 45 to 60 days after emergence. When conditions such as warm, moist soil and high air temperature favor rapid early season growth, the shorter part of the time-to-flower range usually is best. Theoretically, a similar time is also best for the tropics. Only cultivars in maturity groups $I X$ and $X$ flower late enough in the tropics to be considered well adapted.

The U.S.D.A. (United States Department of Agriculture) germplasm collections contain more than 200 entries in maturity groups IX and $X$. Many of these entries have been evaluated at several tropical locations. They proved to be generally low yielding and to have poor agronomic characteristics. However, among the group evaluated near Veracruz, Mexico during the early 1960 's, one was released and named "Tropicana." 
Production of Tropicana increased to about 62,000 hectares by 1974 in the Tampico, Tamaulipas, Mexico, area.

"Jupiter" was released in 1972. Studies at Huastecas Experimental station near Tampico demonstrated that Jupiter yielded about 50\% more than Tropicana, held its seeds much better, and possessed other more desirable characteristics. Jupiter soon replaced Tropicana in the Tampico area of Mexico and by 1977 was grown on about 95,000 hectares. More recently, Jupiter production has been initiated near Tapachula, Chiapas, Mexico (14 $59^{\prime} \mathrm{N}$-latitude).

These results demonstrate the dramatic effect improved cultivars can have on tropical soybean production. They also suggest the need for breeding programs in areas of intended production. During the last decade, new programs have been started. However, progress may be slow because some time will be required to train personnel, accumulate germplasm, and adapt physical facilities.

Jupiter was developed in the breeding program at Gainesville, Florida. The success of Jupiter in tropical areas demonstrated that work at Gainesville can be applicable to these regions. Beginning in 1970, a part of the Gainesville program was directed toward developing soybean genotypes potentially well adapted to tropical regions or to late plantings in souther U.S. These materials were used in the thesis study reported here.

The purpose of this study was to determine the effect of selection at Gainesvill on performance in Mexico and to 
identify specific traits or developmental characteristics which could be selected at Gainesville to improve performance at lower latitudes. 


\section{LITERATURE REVIEW}

Research conducted on soybean in tropical environments has focused primarily on testing existing cultivars and on cultural practices. Results are available which show that soybean can produce acceptable yields in the tropics (Whigham, 1975; Whigham, 1976; Whigham et al., 1978).

Kretschmer (1967) stated that the tropics can be defined as that area enclosed by the Tropic of Capricorn and the Tropic of Cancer, respectively, latitudes $23^{\circ} 27^{\prime}$ south and $23^{\circ} 27^{\prime}$ north of the equator. The tropics can be characterized generally as having ill-defined seasons with little change in daylength. Rainfall occurs throughout the year in some areas; some other areas are characterized by distinct wet and dry seasons, whereas still other areas have little rainfall. Compared with temperate regions, the tropics have short day length with relatively little variation throughout the year. Since length of day is governed by latitude, soybean varieties are adapted to rather narrow belts running east and west in the United States. For convenience, varieties have been divided into 12 maturity groups: $00,0, I$, etc., through $x$. Lower numbered groups are adapted to northern latitudes, and the higher numbered groups are adapted progressively further south. With long days, soybean plants continue to make vegetative growth and under field conditions 
do not produce flowers until the period of daylight has shortened below a critical level. This critical level is specific for each cultivar but is influenced by the age of the plants when day length is near the critical level. Short days reduce the time from flowering to maturity as well as the time from emergence to flowering (Hinson \& Smith, 1967). Cultivars classed in group VIII are the latest grown in continental U.S. In general, cultivars adapted to continental U.S. flower too early to make adequate growth for producing satisfactory seed yields when planted in short-day regions of the world (Hartwig, 1973).

Hartwig (1970) stated that a 45-day period from emergence to early bloom approaches the minimum to permit plants to make adequate growth for producing moderate seed yields and to have pods high enough from the ground to permit machine harvesting without excessive losses.

Introductions are available that will flower later than group VIII cultivars when grown in low latitude regions (Hartwig, 1970). These are presently identified as groups IX and $\mathrm{X}$. Many of these make adequate growth under short-day conditions, but nearly all are indeterminate and have poor agronomic qualities. Jupiter, developed at Gainesville, Florida, has a determinate growth habit and makes good growth under short-day conditions (Hartwig, 1973). The good performance of Jupiter under short-day conditions has been confirmed by Perez and Tijerina (1976) and Judy and Hill (1979). Jupiter is maturity group IX (Hinson, 1972). 
In 1958, the soybean crop was introduced into the northwest of Mexico $\left(27^{\circ}\right.$ to $28^{\circ} \mathrm{N}$-latitude). When production began, farmers relied heavily on the cultivars commercially grown in the United States such as Lee, Hood, Hill, and later Dare, Davis, Bragg. These varieties are in maturity groups $\mathrm{V}$ to VII. When these cultivars were evaluated $14^{\circ}$ to $22^{\circ}$ N-latitude, they showed poor growth, low pod set and obviously low yields (Crispin, 1975). ${ }^{1}$ The poor performance of these maturity group $\mathrm{V}$ through VII cultivars at $14^{\circ}$ and $22^{\circ}$ was associated with their early flowering. Other studies demonstrating that early-maturing cultivars are poorly adapted to low latitude environments include Barrios (1961); Barrios and Ortega (1968); Camacho et al. (1974); Basnet et al. (1974); and Beard et al. (1980).

In 1973 and 1974, the material provided by INTSOY was studied at Tampico, Tamaulipas, Mexico $\left(22^{\circ} 13^{\prime} \mathrm{N}-\right.$ latitude) and the Jupiter cultivar (included in the INTSOY trails) was more promising than Tropicana, the cultivar being grown by farmers in the Tampico area. In 1975, farmers near Tampico began to replace Tropicana with Jupiter and by 1979 were only growing Jupiter (De la Paz et al., 1979). More recently, Jupiter production has been initiated near Tapachula, Chiapas, Mexico ( $14^{\circ} 59^{\prime} \mathrm{N}$-latitude).

Although cultivars ranging in latitude adaptation from $50^{\circ}$ to $0^{\circ}$ are available, soybean breeding programs have not

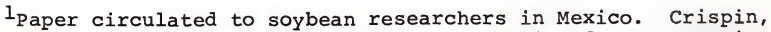
M.A. 1975. The search for soybean varieties for the tropical lowlands of Mexico. 
yet met cultivar needs for many tropical areas (Hinson \& Hartwig, 1977). Tropical environments are highly variable not only from one location to another, but also from year to year at a particular location.

Crispin (1975) listed five problems commonly found with the soybean crop in tropical areas of Mexico:

1. Excess rainfall hinders cultivation and enhances fungal and bacterial diseases.

2. Cloud cover is highly variable and unpredictable. This causes inconsistent performance and unreliable experimental results.

3. High relative humidity when plants mature is common. This causes seeds to germinate in pods of some cultivars.

4. Abnormally long rainy periods causes nonuniform maturity. Some plants renew vegetative growth even when pods have already matured.

5. Severe chlorosis is commonly observed even when micronutrients are used and seeds are inoculated.

Another problem common to soybean in the tropics was discussed in the 1980 INTSOY Newsletter (anonymous, 1980). Producers have difficulty obtaining good quality seed for planting. All soybean seeds are capable of carrying many kinds of microorganisms and viruses. Seedborne microorganisms include various fungi (molds) and bacteria, many of which can cause disease in soybean plants. Some of the important effects of these microorganisms are reductions in storage life, germination, emergence, vigor, and eventually yields. The writer related the disease situation to storage 
life of the soybean under tropical conditions in Puerto Rico and concluded that soybean fields used for producing seeds should be located in areas where dry conditions prevail during maturation of the seeds. Basnet et al. (1974) reached the same conclusion from a two-year study in Sikkim (Hilalayan Kingdom). The later maturing cultivar which matured during favorable harvest weather produced good seed quality. Earlier maturing cultivars did not.

Although soybean can be grown during the entire year under tropical conditions or short-day environments, the above findings suggest that planting dates must be selected in order for the plants to reach maturity during dry weather conditions. The existence of extreme environmental variation emphasizes that data obtained in any one year or at any one site cannot be considered as an adequate basis for varietal recommendation. Thus, a measure of the relative stability of cultivars under a wide range of environmental conditions becomes necessary in determining efficient breeding procedures. Information obtained from estimates of the various cultivar $x$ environment interactions are useful in an efficient variety evaluation program (Liang et al., 1966).

Genotype-environment interactions have been of concern to plant breeders for many years (Eberhart \& Russell, 1966). The presence of genotype-environment interactions complicate evaluation procedures and reduce the efficiency of genetic advance through selection (Comstock \& Moll, 1963). The cause of genotype-environment interactions is not always known. 
Oka (1975) stated that when a number of soybean cultivars are tested at different locations or in different years, a large genotype-environment interaction masking genotypic variation is often observed even though no marked difference could be detected among the environments.

From 1954 through 1956, entries in Uniform Regional soybean trials of several maturity groups, including VI and VII, remained unchanged for three years. Data collected have been studied in various ways. Schutz and Bernard (1967) suggested that locations may be effectively substituted for years in regional tests to permit a rapid turnover of breeding material. Brim (1973) stated that further analyses indicated a distinct potential for developing cultivars with specific adaptation to subregions within the area sampled by maturity groups VI and VII tests.

Frey and Maldonado (1967) suggested that the following five factors may contribute to cultivar x location interactions in oats within Iowa: (a) soil fertility, (b) moisture supply, (c) density of stand, (d) pests, and (e) temperature fluctuations. All of these factors may be even more important in contributing to cultivar $\mathrm{x}$ location interactions in soybean tests conducted at Gainesville, Florida and Tampico, Mexico. Soil properties are distinctly different at the two locations. The Gainesville soil is sandy, slightly acid, high in $\mathrm{P}$, moderately low in $\mathrm{K}$; whereas the Tampico soil is clay, alkaline ( $\mathrm{pH}$ nearly 8.0 ), low in $\mathrm{P}$, and high in $\mathrm{K}$. These factors suggest that the probability of effectively 
selecting soybean genotypes at Gainesville for performance at Mexico may be low. However, Jupiter was selected at Gainesville and it performs very well in Mexico. Further, Baihaki et al. (1976) concluded that despite cultivar $\mathrm{x}$ environment interactions in soybean, superior cultivars can be identified from single environment preliminary yield tests.

Experimental evidence in soybean has shown that flowering date, plant height, harvesting date, resistance to disease, lodging, and shattering are characters with high heritability, but yield is a character with low heritability. Hanson et al. (1962) indicated that, unless a soybean breeder is dealing with a cross which gives an extreme range of progenies, visual discrimination should be used primarily to discard the poor-yielding cultivars. Byth et al. (1969b) suggested that a visual estimation of canopy shape during pod development may be of value in discriminating highyielding cultivars in advanced generation soybean populations, and that the utility of this selection procedure may be relatively constant across environments. Kwon and Torrie (1964) indicated that the expected gain for yield using visual selection on a single plot basis was approximately $50 \%$ as efficient as selection based on plot yield. This and the low heritability of seed yield suggests that a breeder may be better off to advance lines in early generations based upon performance for traits other than yield. Byth et al. (1969a) indicated that actual advance 
evaluated over environments may be the only accurate criterion for comparison of selection procedures in the presence of substantial cultivar $\mathrm{x}$ environment interactions. Teixeira (1977) found significant cultivar $x$ planting date interaction at Gainesville. He attributed the interactions to large differences in plant growth associated with maturity class and planting date. Because plants in his late planting made about the same amount of growth that the same cultivars normally make in tropical environments, he suggested that it is likely that selection at Gainesville, on the basis of performance in mid-July planting, may be effective selection for performance at low latitudes. 
MATERIALS AND METHODS

Since this research includes two types of experiments, the materials and methods are presented in two parts.

\section{Experiment 1}

Six hundred twenty-one individual plants were selected from mid-July plantings at Gainesville, Florida [USA] in 1977. Plants were selected for adaptation to late (mid-July) plantings at Gainesville. Potential adaptation to lowerlatitude environments was also considered. Enough seed was harvested from each plant to produce two plant progeny rows. Rows were planted at two locations in 1978: Gainesville (planted July 19) and Tancasneque, Tamaulipas [Mexico] (planted July 25). At each location, row numbers started with 1001 and a Jupiter check was included every 50th row beginning with row number 1013. "UFV-1" served as an additional check in every 50th row beginning with row number 1038 .

From these plant rows grown in 1978, 38 plant rows which appeared to have good adaptation to Tancasneque, were selected at Tancasneque. Similarly, the 38 rows which appeared to have good potential for late planting at Gainesville, were selected at Gainesville. Table 1 gives the progenitors, generation, number of lines grown from each 


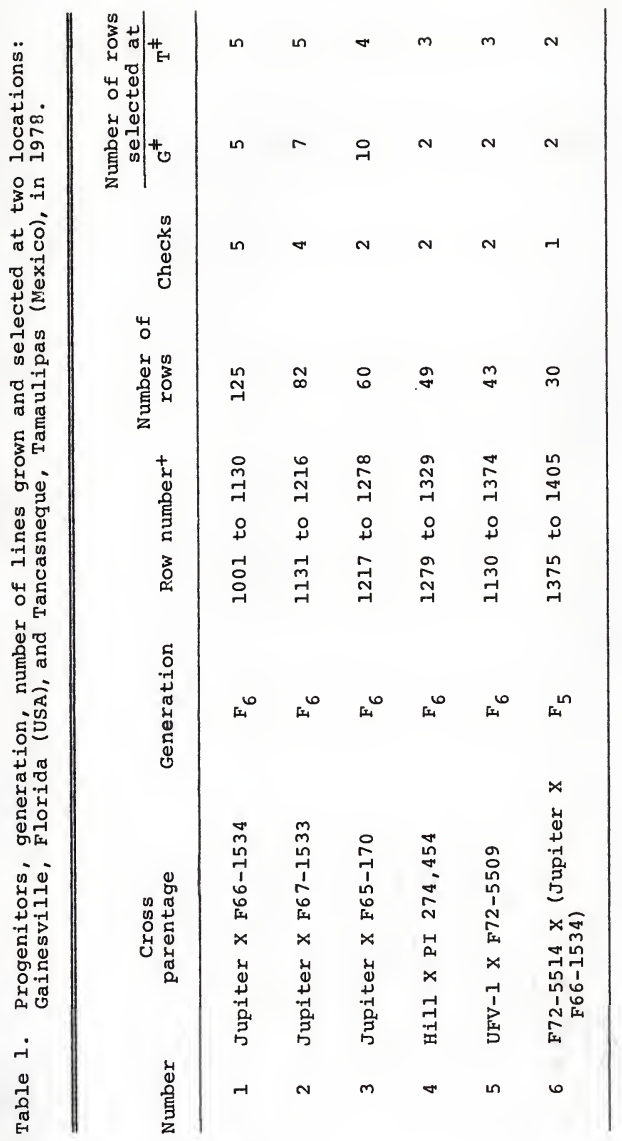




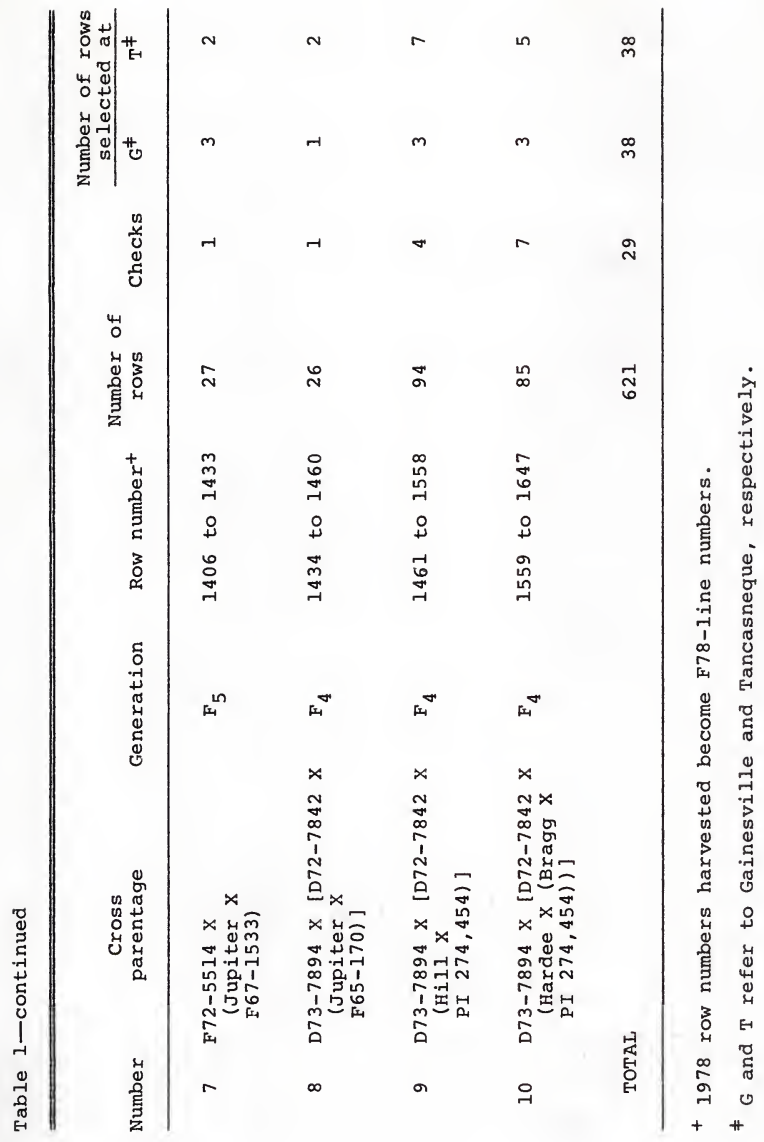


cross, and the number of lines selected from each cross at each location.

In selecting the final 38 rows at each location, two points were considered: (1) having the number of rows selected from each cross proportional to the number of rows grown, and (2) including the very best appearing rows at each location. For example, rows from cross 3 appeared to be especially well adapted at Gainesville, but less well adapted in Tancasneque. Therefore, we selected 10 and four rows from cross 3 at Gainesville and Tancasneque, respectively.

\section{Evaluations}

To reduce soil variability within tests, the 76 selected lines were divided into two groups of 38 each with Jupiter and UFV-1 as checks to make 40 entries per test. Since there will be some advantages to having all selections from a particular cross in one test, the arrangement given in Table 2 was made.

Seed supplies in Gainesville for some selected lines were adequate for planting only 12 rows with 200 seeds per row; therefore, the reasoning used was that near maximum information would come from planting these 76 lines at three locations with each location having two replications of two-row plots. The locations were: Gainesville $\left(29^{\circ} 30^{\prime}\right.$ N-latitude); Tancasneque (22 ${ }^{\circ} 13^{\prime} \mathrm{N}-$ latitude), and Tapachula, Chiapas (Mexico), (14\% 59' N-latitude). 
Table 2. Arrangement of the lines selected in 1978 by cross and test for 1979 evaluation.

Test $1979, \mathrm{~A}-1$

Number of lines selected

Cross $^{+}$Gainesville Tancasneque
Test 1979, A-2

Number of lines selected Cross $^{+}$Gainesville Tancasneque

\begin{tabular}{llllll}
\hline 1 & 5 & 5 & 3 & 10 & 4 \\
2 & 7 & 5 & 4 & 2 & 3 \\
7 & 3 & 2 & 5 & 2 & 3 \\
8 & 1 & 2 & 6 & 2 & 2 \\
10 & 3 & 5 & 9 & 3 & 7 \\
TOTAL & 19 & 19 & & 19 & 19 \\
\hline
\end{tabular}

+ See Table 1 for parents in each cross. 
Table 3 gives dates of planting, number of entries, number of replications, rows per plot, row length, row width, area harvested for each test, and locations.

Characters measured on a plot basis were: Number of days from planting to:

$$
\begin{array}{r}
\text { Beginning flower- } 50 \% \text { of plants produced at least } \\
\text { one open flower }
\end{array}
$$

Maturity-90\% dry pods

Plant height-stem length at maturity (centimeters)

Weight/100 seeds-sample by replication (grams)

Total nodes at maturity-1980 only.

1980 Evaluation

From each 1979 test, 21 lines were selected for good performance at Gainesville, Tancasneque or at both locations. Jupiter, UFV-1, and "F75-9207," were added as checks to make 24 entries per test. These two tests were planted at Gainesville, Tancasneque, Tapachula and Boliche. The Boliche station is located in Ecuador, South America $\left(2^{\circ} 15^{\prime}\right.$ S-latitude).

The materials and methods for 1980 are also given in Table 3. Characters measured on a plot basis were the same as in 1979 evaluation.

Since Tapachula had nearly 1 meter of rainfall during the first 30 days after planting (1979) a complete loss of the experiments was suffered. 


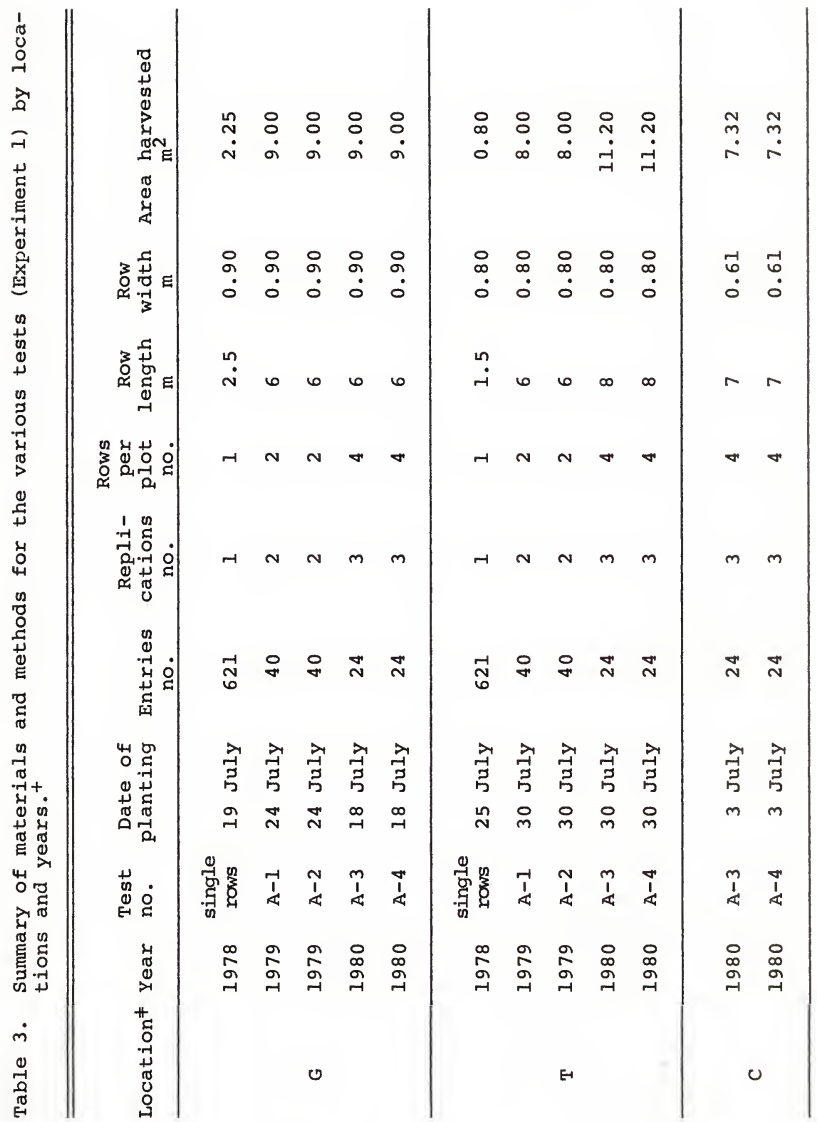




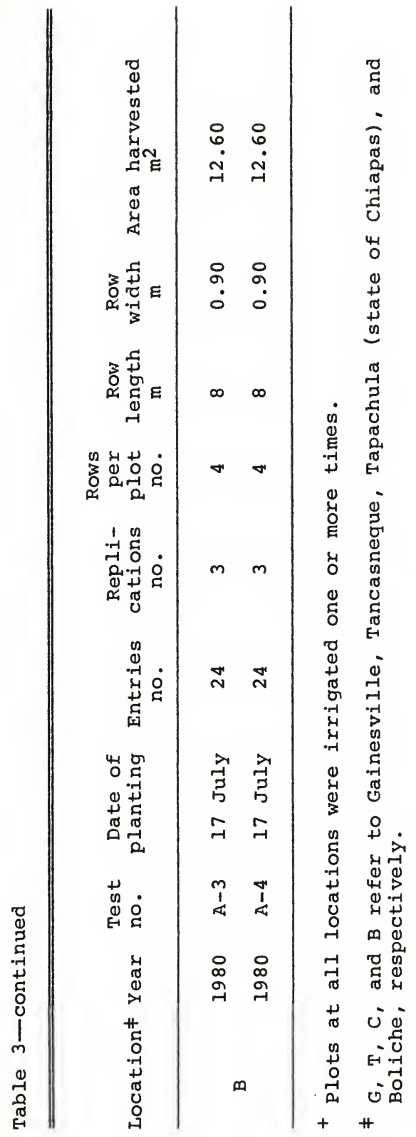




\section{Experiment 2}

\section{Evaluation}

Breeding lines were selected for their potential to produce cultivars adapted to late plantings in Florida. Ninety-four lines (from 296 grown) were selected from 1977 field plots. After harvest, these 94 lines were further reduced to 42 lines selected for high seed yield, diverse parentage, and growth characteristics expected to favor adaptation to tropical latitudes. The 42 lines selected were divided in two sets of 20 and 22 lines. Jupiter and UFV-1 were added as checks to make 22 and 24 entries per test. Tables 4 and 5 give the lines, parentage, and generation for entries in Test $\mathrm{B}-1$ and Test $\mathrm{B}-2$, respectively. These two tests were planted at Gainesville and Tancasneque.

Table 6 gives the date of planting, number of entries, number of replications, rows per plot, row length, row width, and area harvested by locations. Characters measured on a plot basis were the same as in Experiment 1 .

\section{9, 1980 Evaluations}

From the tests in 1978, 11 lines were selected from each test for their good performance in Gainesville, Tancasneque, or both locations. For 1979 and 1980 evaluations, the 11 lines selected from each test (B-1 and $\mathrm{B}-2$ ) were combined into one test designated B-3 (1979) and B-4 (1980). Jupiter and UFV-1 were added as checks to make 24 entries. These tests were planted at Gainesville, Tancasneque, Tapachula and Boliche. 
Table 4. Soybean breeding lines, their parentage and generation composited selected for Test 1978, B-1.

Line

Parentage

Generation composited

Jupiter

UFV-1

F76-6719

F76-6724

F76-6728

F76-7087

F76-7095

F76-7113

F76-7145

F76-7215

F76-7295

F76-7298

F76-7323

F76-7326

F76-7333

F76-7336

F76-6938

F76-7000

F76-7351

F76-7376

F76-6854

F76-6858

F76-7162

F76-7205 check

check

F64-2571 X (D60-7965 X F64-2862)

$\mathrm{F}_{8}$

same

same

same

same

same

same

same

same

same

same

same

same

same

same

Jupiter X F66-1534

$\mathrm{F}_{6}$

same

same

same

same

same

same

same

same

same

same

Jupiter subline

Jupiter subline

Hardee X (Bragg X PI 274,454)

$\mathrm{F}_{6}$

same

same

F57-1471 X F58-3726

$\mathrm{F}_{15}$

D49-2491 (2) X PI 230,201

$\mathrm{F}_{10}$

Hill (2) X PI 274,454

$\mathrm{F}_{7}$ UFV-1 subline 
Table 5. Soybean breeding lines, their parentage and generation composited selected for Test 1978, B-2.

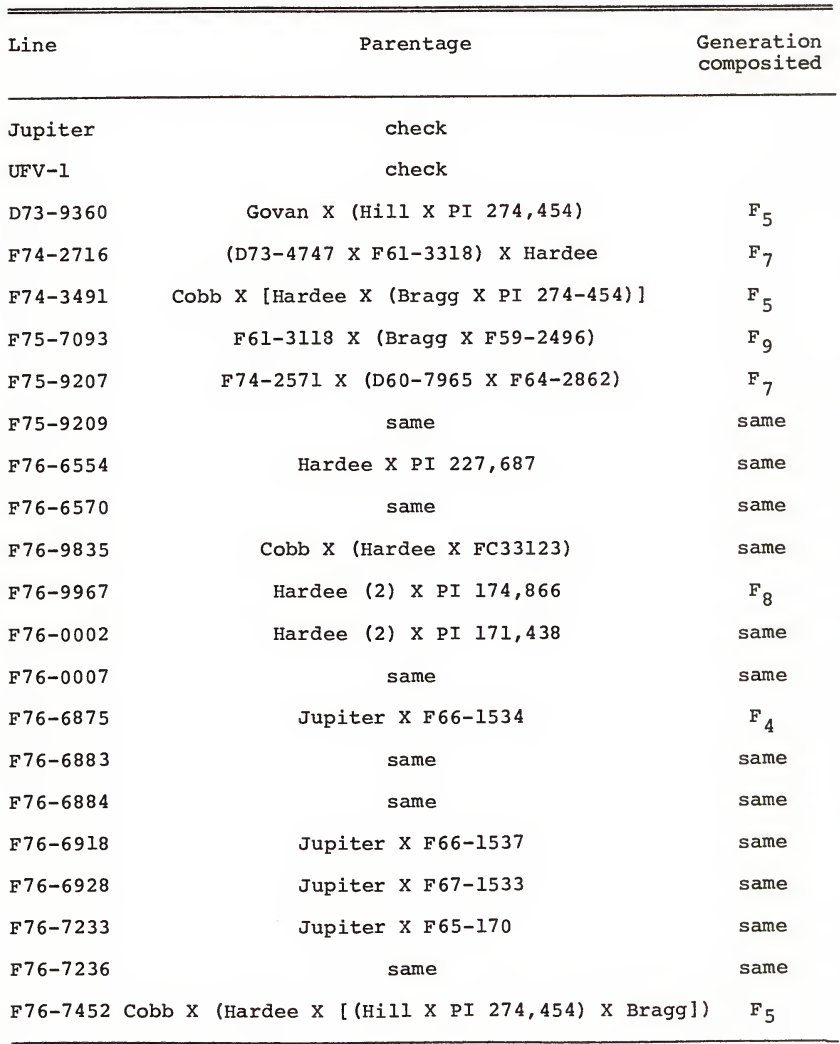




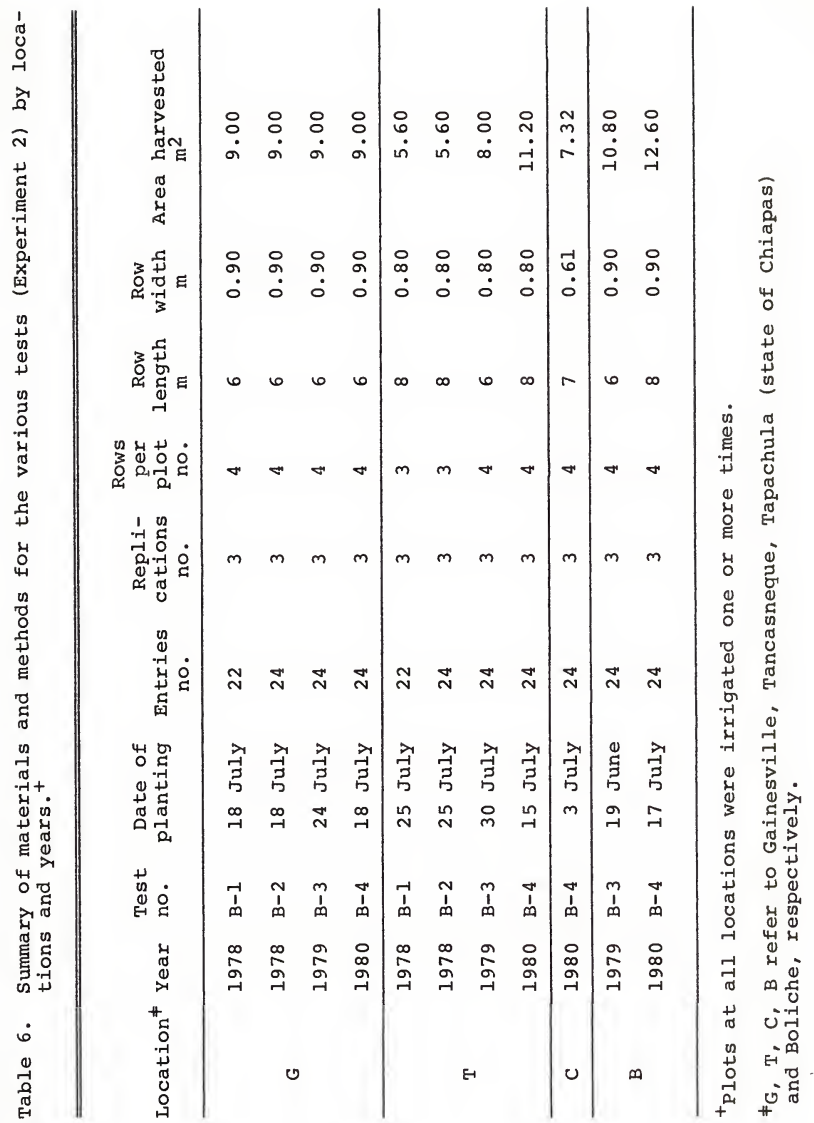


As was indicated before (Experiment 1), the Tapachula location (1979) had nearly 1 meter of rainfall during the first 30 days of planting; therefore, a complete loss of the experiment was suffered. Additional information on methods (date of planting, number of entries, number of replications, etc.) is given in Table 6 by locations and years. Characters measured on a plot basis were the same as in 1978 evaluation (see Experiment 1).

Statistical Analyses

For yield evaluations (Experiments 1 and 2) genotypes were arranged in randomized block designs with two or three replications. Analyses of variance were carried out for yield in each test at each location for each year using the mixed model:

$$
y_{i j}=\mu+G_{i}+B_{j}+e_{i j}
$$

where,

$y=$ the observation from the $i \frac{\text { th }}{\text { genotype }}$ in the $j$ th block

$M=$ the overall mean for all the observations

$G_{i}=$ the fixed effect of the $i$ th genotype

$B_{j}=$ the random effect of the $j \frac{\text { th }}{b l o c k}$

$e_{i j}=$ the error in $y_{i j}$

Expected mean squares for each source of variation are:

Source of variation

Replications

Genotypes d. $f$.

E (MS)

$r-1$

$g-1$ $\sigma^{2} e+g \sigma^{2} r$

$\sigma^{2} e+r \sigma^{2} g$ 
Error

$$
(g-1)(r-1)
$$$$
\sigma^{2} e
$$

where,

$$
\begin{aligned}
& r=\text { the number of replications } \\
& g=\text { the number of genotypes }
\end{aligned}
$$

Combined analyses of variance were also performed. For these analyses, the model used was:

$$
y_{i j k}=\mu+G_{i}+B_{j}+L_{k}+G L_{i k}+e_{i j k}
$$

where,

$$
\begin{aligned}
y_{i j k}= & \text { the observation for the } i \frac{\text { th }}{} \text { genotype in } \\
& \text { the } j \frac{t h}{b l o c k} \text { and } k \frac{\text { th }}{10 c a t i o n} \\
L_{k}= & \text { the random effect of the } k \frac{\text { th }}{G o c a t i o n} \\
G L_{i k}= & \text { the interaction effect of the } i \frac{\text { th }}{} \\
& \text { genotype on the } k \frac{\text { th }}{\text { location }}
\end{aligned}
$$

Expected mean squares for each source of variation are:

Source of variation

Locations

Replications within locations

Genotypes

Genotypes $\mathrm{x}$ locations

pooled error

where, d.f. $\quad E$ (MS)

$$
\text { e-1 }
$$$$
\ell(r-1)
$$$$
g-1
$$$$
(g-1)(\ell-1)
$$$$
\ell(g-1)(r-1)
$$$$
\sigma^{2} A+r g \sigma_{l}^{2}
$$$$
\sigma^{2} A
$$$$
\sigma^{2} e+r \sigma_{g l}^{2}+r l \sigma_{g}^{2}
$$$$
\sigma^{2} e+r \sigma_{g l}^{2}
$$

$\sigma^{2} e$

\section{$l=$ the locations}

For genotypes evaluated two or more years, the following model was used: 


$$
\begin{aligned}
y_{i j k l}= & +G_{i}+B_{j}+L_{k}+y_{\ell}+G L_{i k}+G y_{i l}+ \\
& G L y_{i k \ell}+L y_{k l}+e_{i j k l}
\end{aligned}
$$

where,

$$
\begin{aligned}
& y_{i j k l}=\text { the observation for the } i \text { th } \text { genotype } \\
& \text { in the } j \text { th block, in the } k \text { th location and } \\
& \text { the } \ell \stackrel{\text { th }}{\text { year }} \\
& y_{\ell}=\text { the random effect of the } \ell \frac{\text { th }}{\text { year }} \\
& G y_{i l}=\text { the interaction effect of the } i \text { th } \\
& \text { genotype on the } \ell \stackrel{\text { th }}{\text { year }} \\
& G L y_{i k \ell}=\text { the interaction effect of the } i \text { th }
\end{aligned}
$$

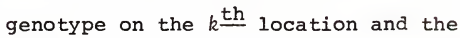

$$
\begin{aligned}
& \ell \stackrel{\text { th }}{\text { year }}
\end{aligned}
$$

Expected mean squares for each source of variation are shown below.

Source of Variation

Locations
Years

d. f.

E (MS)$$
\sigma_{A}^{2}+r \sigma^{2} g l y
$$$$
+r g \sigma^{2} y \ell
$$$$
+r g y \sigma^{2} \ell
$$

Years X Locations
$\sigma_{A}^{2}+r g \sigma^{2} y \ell$ 
Source of Variation

d.f.

$E(M S)$

Replications within

Locations and Years

$y \ell(r-1)$

$\sigma_{A}^{2}$

Genotypes

$(g-1)$

$$
\begin{aligned}
\sigma^{2} e & +r \sigma^{2} g \ell y \\
& +r y \sigma^{2} g \ell \\
& +r \ell \sigma^{2} g y \\
& +r y \ell \sigma^{2} g
\end{aligned}
$$

Genotypes X Years

$$
(g-1)(y-1)
$$

$\sigma^{2} e+r \sigma^{2} g \ell y$

$+r \ell \sigma^{2} g y$

Genotypes x Locations

$$
(g-1)(\ell-1)
$$

$\sigma^{2} e+r \sigma^{2} g \ell y$

$$
+r y \sigma^{2} g l
$$

Genotypes X Locations $\mathrm{X}$ Years

$$
(g-1)(\ell-1)(y-1)
$$$$
\sigma^{2} e+r \sigma^{2} g \ell y
$$

Pooled Error

$$
y \ell(g-1)(r-1)
$$

$\sigma^{2} e$

Simple correlation coefficients were calculated for some variables, depending on the interest to explain several important points.

During and at the end of Test 1, Experiment 1 (1979, A-1), a distinct soil gradient was observed at the Tancasneque 
location, therefore an adjusted plot yield was made using the moving average procedure suggested by Dr. E. S. Horner ${ }^{2}$ (1980, personal communication). We calculated the moving average for each plot using six adjacent plots (three on each side). The plot in question was not included. The average of the replication of the moving average values was divided by the moving average of a particular plot and this ratio was multiplied by the original plot yield. If the ratio was more than 1.0, the plot yield was increased proportionately. If the ratio was less than 1.0 , the plot yield was reduced proportionately.

${ }^{2}$ Professor of Agronomy, University of Florida. 


\section{RESULTS AND DISCUSSION}

\section{Experiment 1}

At Gainesville, the 38 Tancasneque selections averaged 198 grams of seed per 1.0 meter of row length, and the 38 Gainesville selections averaged 285 grams of seed per 1.0 meter of row length, or $44 \%$ more.

At Tancasneque, the 38 Tancasneque selections averaged 145 grams of seed per meter of row length. Data on yield of Gainesville selections at Tancasneque were not recorded.

Although it is generally recognized that selection for superior-appearing (and superior-yielding) plant rows usually is little better than random selection, three observations suggested that selection at each location may have included rows with specific adaptation to that particular location. First, the 448 increase in average row yields at Gainesville for Gainesville selections over Tancasneque selections is substantial. Second, no rows selected at one location were included in selections at the other location. The 38 rows selected at each location represent $6 \%$ of the total; therefore, with random selection, $6 \%$ of 38 or two rows would be expected to be included in both groups. Third, soil properties at the two locations differ drastically. The Gainesville soil is sandy with $\mathrm{pH}$ corrected to no more than 6.2; whereas the Tancasneque soil is clay with a pH of about 
8.0. Many 1978 Tancasneque rows showed evidence of iron chlorosis. For these reasons, 1979 and 1980 yield tests were designed and analyzed in ways to provide maximum information on the cultivar (breeding line) $x$ location interactions.

1979 and 1980 Evaluations

The 38 selections from Gainesville and the 38 selections from Tancasneque were distributed equally between two tests designated $1979 \mathrm{~A}-1$ and $\mathrm{A}-2$ (Table 2). Each test contained 38 selected lines and two check cultivars. In 1980 the entries in each test were reduced to 21 breeding lines plus three checks. These tests are designated $1980 \mathrm{~A}-3$ and 1980 $\mathrm{A}-4$. Results from test $1979 \mathrm{~A}-1$ and entries retained from it (Test $1980 \mathrm{~A}-3$ ) will be discussed first. For convenience in discussing these future results, one term is needed to refer to a group of entries which includes both breeding lines and cultivars. The term "genotype" will be used for this purpose.

At Tancasneque in 1979, a soil gradient in the area where Test 1 was grown was especially noticeable. Replications were inadvertently arranged in a way to maximize (rather than minimize)soil variability within blocks. Some procedure to adjust plot values was needed to increase precision. The moving average, described in Materials and Methods, was used.

Table 7 shows mean squares for yield analyses at Gainesville and at Tancasneque with and without adjusted plot yields. Adjusting plot yields at Tancasneque reduced the 


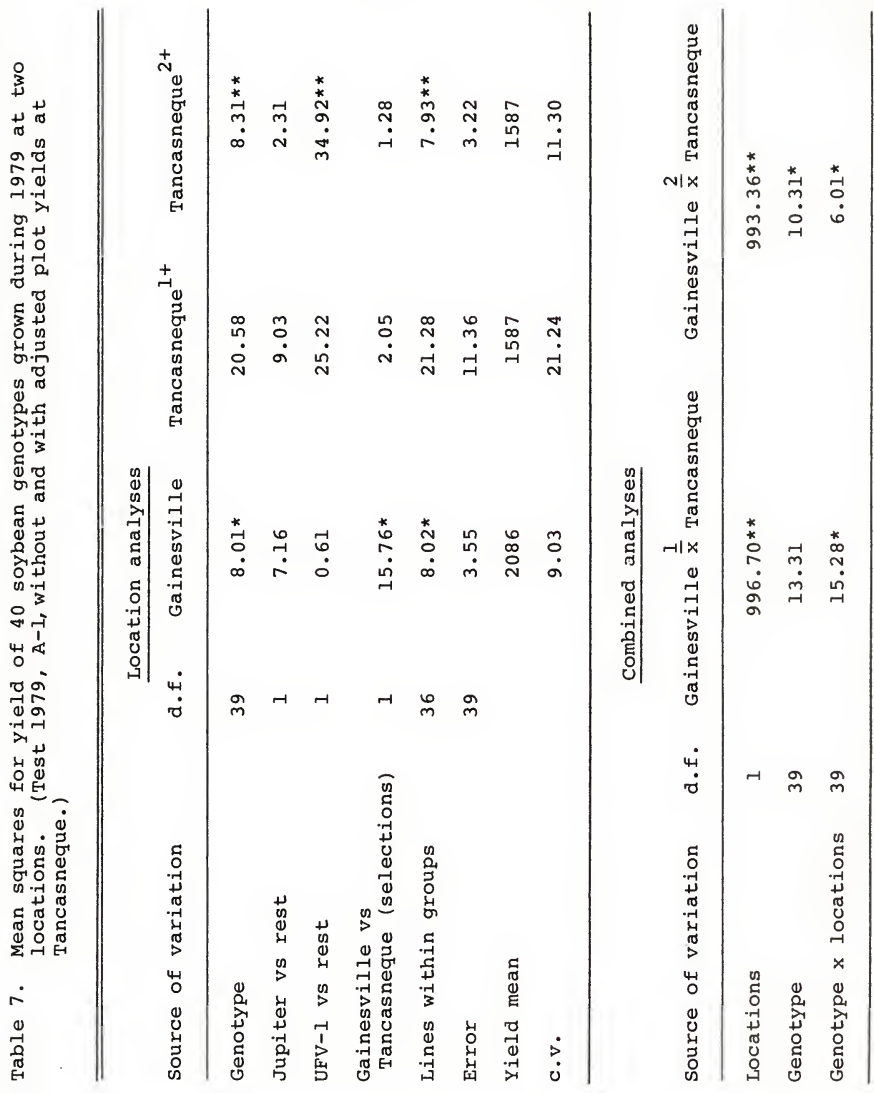




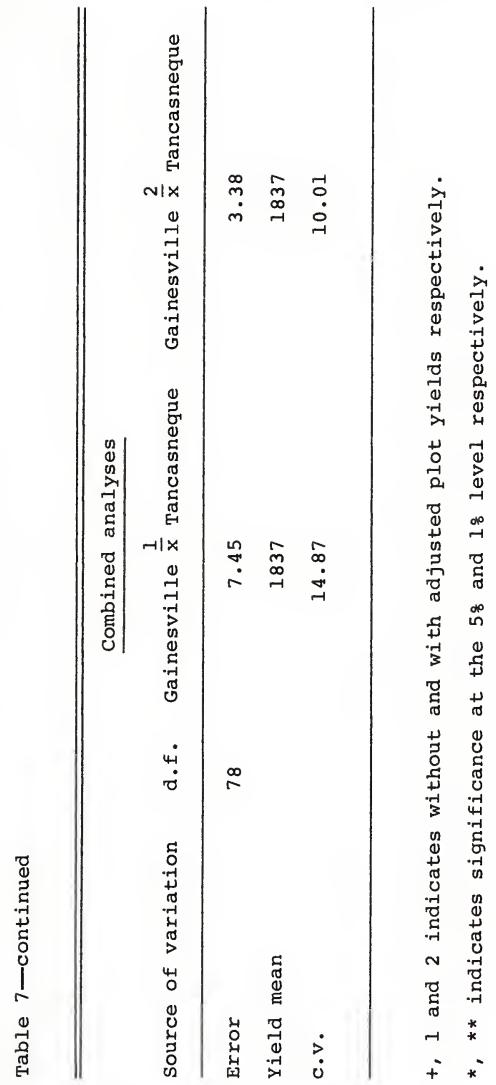


coefficient of variability from 21.24 to 11.30 and thereby increased significance levels of comparisons of primary interest. Therefore, adjusted yield values will be used in subsequent discussions.

The 40 genotypes means were significantly different at the 0.05 and 0.01 levels of significance at Gainesville and Tancasneque, respectively (Table 7). At Gainesville, neither Jupiter nor UFV-1 differed from the mean of the 38 test lines. At Tancasneque, Jupiter did not differ significantly from the mean of the test lines, but UFV-1 was significantly above the mean $(\underline{p}<0.01)$. However, when this source of variability was removed, highly significant differences among lines remained.

These observations illustrate two important points: (a) There is genetic variability for yield among test lines at both locations, and (b) the average yield of test lines is similar to that of the better check cultivars in the same maturity range.

of particular interest, however, are the mean squares for Gainesville vs. Tancasneque selections. At Gainesville the mean square was significant at 0.05 , but at Tancasneque it was not. At Gainesville, mean yields of the 19 lines selected at Gainesville $(2135 \mathrm{~kg} / \mathrm{ha})$ was significantly larger than the mean of the 19 Tancasneque selections $(2044 \mathrm{~kg} / \mathrm{ha})$; whereas at Tancasneque, the Gainesville and Tancasneque selections yielded 1561 and $1587 \mathrm{~kg} / \mathrm{ha}$, respectively. These data suggest that selection at Gainesville improved the yield 
potential for Gainesville, but that selection at Tancasneque had no significant effect on the yield potential for Tancasneque. Detailed data on all genotypes at both locations are given in appendix Tables 1 and 2. Since four of the six highest yielding lines at Tancasneque were Tancasneque selections, there is a slight indication that selection at Tancasneque was also effective for Tancasneque.

After variation resulting from checks vs. selected lines and mean of Gainesville selections vs. Tancasneque selections was removed, 36 degrees of freedom remained for testing variation among lines within Gainesville and within Tancasneque selections. The mean square for lines within groups was significant at the 0.05 and 0.01 levels at Gainesville and Tancasneque, respectively (Table 7). This indicates about the same amount of variation for lines within groups as between groups at Gainesville and considerably more variation within than between at Tancasneque.

Table 7 also gives mean squares for combined analysis. There was a significant genotype effect over locations and the genotype $x$ location interaction was significant. Evidence indicates that the significant genotype $\mathrm{x}$ location interaction was more likely due to unequal relative performance of lines within groups than to unequal performance of groups.

In order to identify genotypes which contributed greatly or slightly to the significant genotype $x$ location interaction, the genotype mean was expressed in test mean 
percentages at each location, a procedure used by stuber et al. (1973). Genotype means, which vary from test means at each location by about the same percentage amount and in the same direction, contribute little to genotype $\mathrm{x}$ location interaction. These genotypes are identified in Table 8. Genotypes which vary from test means in different directions or by substantially different amounts contribute more to the interaction. These are identified in Table 9.

Sixteen lines contributed little to the interaction. Ten were Gainesville selections; six were Tancasneque selections. The correlation coefficient for yield at the two locations was $0.83(\mathrm{p}<.01)$.

Twelve lines and the two checks (Table 9) apparently contributed most to the genotype $x$ location interaction. Nine were Tancasneque selections and three were Gainesville selections. The correlation coefficient for yield at the two locations was negative but nonsignificant $(r=-0.25)$.

To summarize, the 1979 data showed significant genotype effects at each location and over both locations. It also indicated a significant genotype $x$ location interaction and gave some indication that selection at a particular location improved performance at that location.

In 1980,21 of the 38 lines were selected for retesting (Test 1980, A-3). Three checks were added to make 24 entries. Selected lines included those performing best at Gainesville, at Tancasneque, and at both locations in 1979. The 21 lines included nine which contributed little to the genotype $x$ 
g

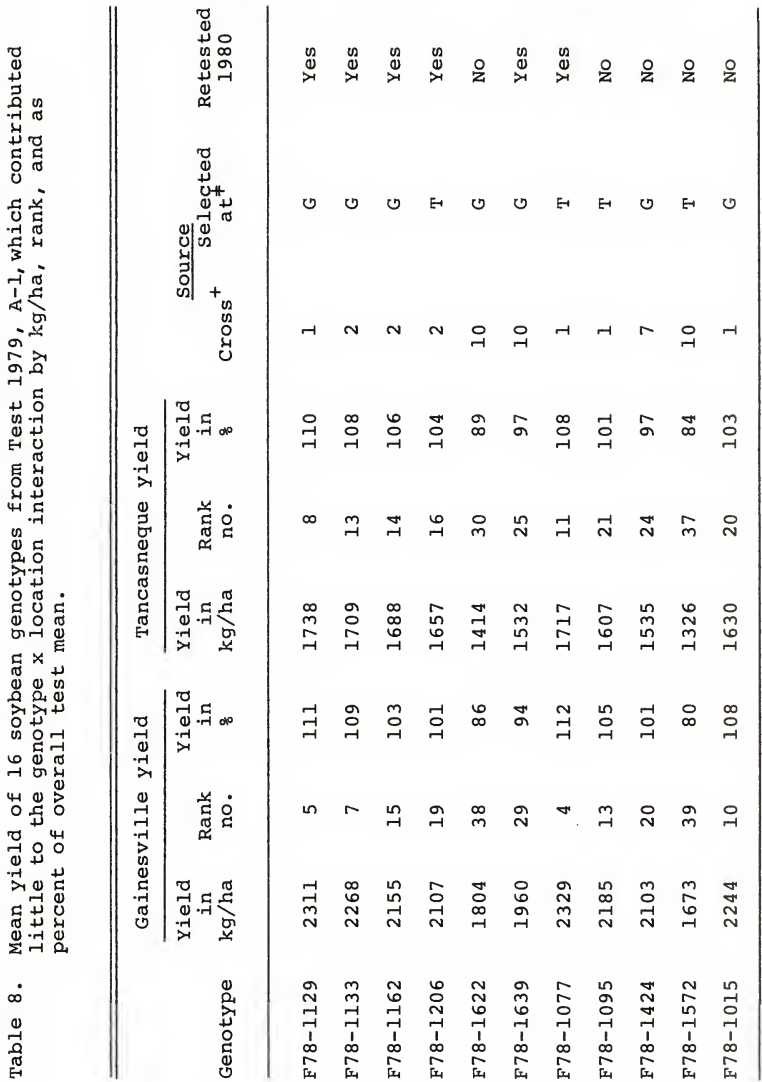




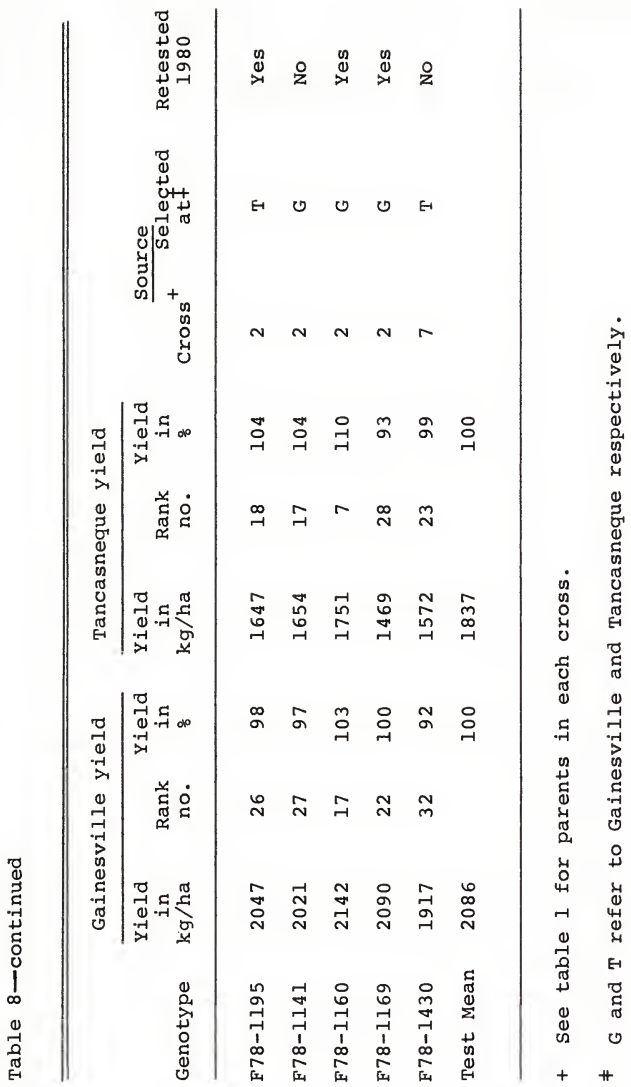




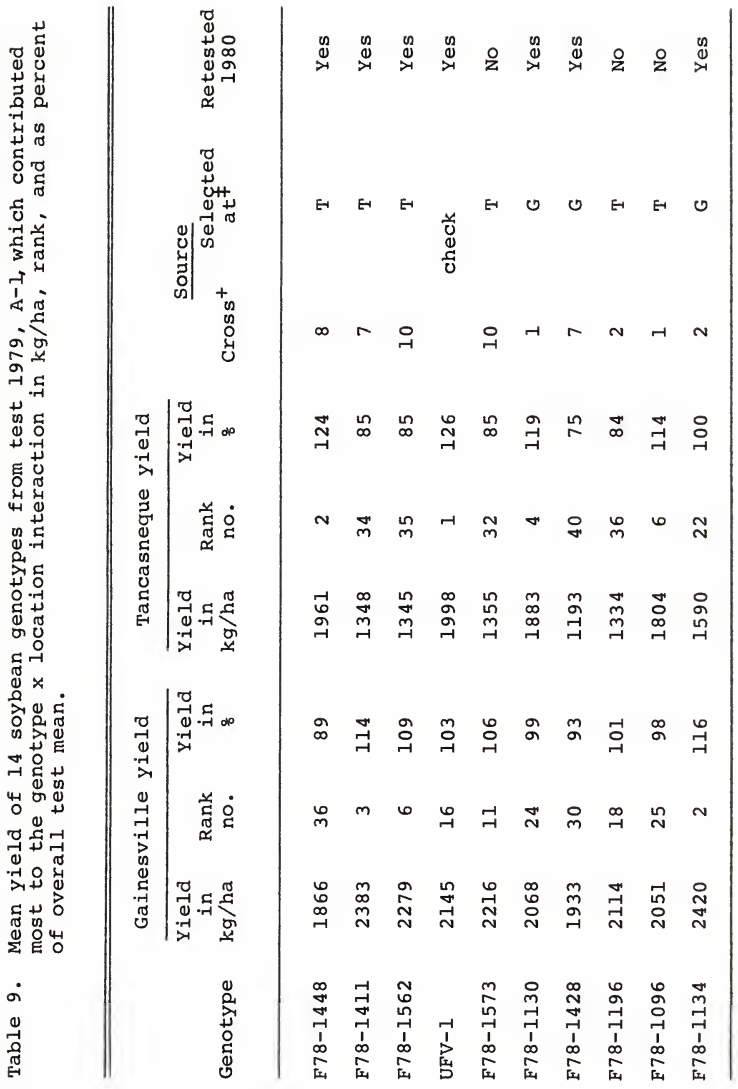




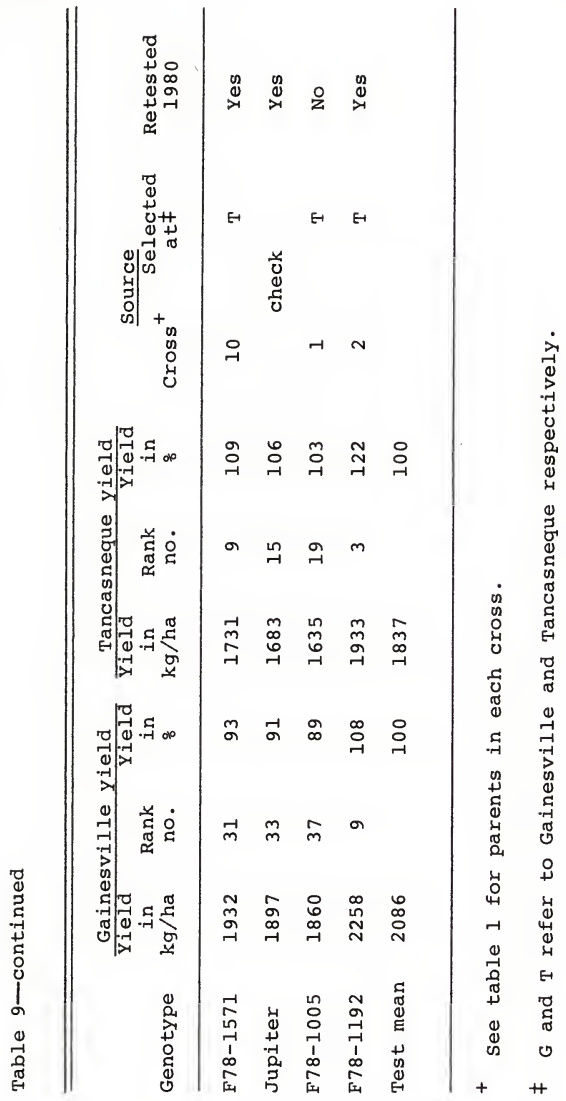


location in 1979 (Table 8) and 10 genotypes (including Jupiter and UFV-1) which contributed more to the interaction (Table 9). In 1980, replicated yield tests of these genotypes were conducted at four locations: Gainesville, Tancasneque, Tapachula, and Boliche. Because initial selections were made at Gainesville and Tancasneque, data from these two locations will be presented first, followed by data from Tapachula and Boliche.

Mean squares from analyses of data from Gainesville and Tancasneque are presented in Table 10. Genotype effects were highly significant at each location and in the combined analysis, but the genotype $\mathrm{x}$ location interaction was nonsignificant. This suggests that location effects were less important than year effects at one of the locations; therefore, analyses were performed with the group of genotypes studied in both years.

Mean squares from combined analyses for Gainesville 1979 vs. 1980 and Tancasneque 1979 vs. 1980 are presented in the bottom of Table 10. The genotype $x$ year interaction was nonsignificant for Gainesville but highly significant for Tancasneque. Considering all four environments, data from Tancasneque 1979 appear to be more atypical.

Table 11 shows 1980 mean squares for yield at Tapachula and Boliche. The 24 genotype means were significantly different at the 0.01 level at Boliche, but nonsignificant at Tapachula. Detailed data on all genotypes at the four locations are given in Tables 3 and 4 of the Appendix. 
Table 10. Mean squares for yield of 24 soybean genotypes grown during 1980 at two locations (Test 1980, $\mathrm{A}-3)$.

\section{Location analyses}

Source

d.f.

Gainesville

Tancasneque

\begin{tabular}{lccc} 
Replications & 2 & $342.19 * *$ & $12.10 *$ \\
Genotype & 23 & $6.32 * *$ & $11.33^{* *}$ \\
Error & 46 & 2.81 & 3.23 \\
Yield mean & & 1686 & 1594 \\
c.v. & 9.94 & 11.27 \\
\hline & Combined analyses & \\
Source & d.f. Gainesville X Tancasneque \\
\hline Location & 1 & 30.84 \\
Genotype & 23 & $13.14 * *$ \\
Genotype X location & 23 & 4.50 \\
Error & 92 & 3.02 & 1640 \\
Yield mean & & 10.59 \\
c.v. & & \\
& &
\end{tabular}

Combined analyses for years at each location

Source d.f. Gainesville

Tancasneque $1979 \times 1980$ $1979 \times 1980$

\begin{tabular}{lccc}
\hline Year & 1 & 157.62 & $17.38 *$ \\
Genotype & 22 & $11.13^{*}$ & 8.18 \\
Genotype x year & 22 & 4.55 & $6.12 * *$ \\
\hline
\end{tabular}


Table 10-continued

\begin{tabular}{lccc}
\hline Source & d.f. & $\begin{array}{c}\text { Gainesville } \\
1979 \times 1980\end{array}$ & $\begin{array}{c}\text { Tancasneque } \\
1979 \times 1980\end{array}$ \\
\hline Error & 44 & 3.07 & 1.94 \\
Yield mean & & 2006 & 1609 \\
C.v. & & 8.73 & 8.65 \\
\hline
\end{tabular}

*, ** Indicates significance at the $5 \%$ and $1 \%$ level, respectively. 
Since this experiment was carried out at four locations in 1980, the mean squares for the interactions among these locations are of particular interest. Mean squares from analyses involving various location combinations are shown in Table 12.

The 24 genotype means were significantly different at the 0.01 level in three of the eight location combinations studied and significant at the 0.05 level in two other location combinations (Table 12). However, the genotype $\mathrm{X}$ location interaction was significant in only three of the eight combined analyses shown in Table 12 and it was not significant in another combination shown in Table 10.

Table 11. Mean squares for yield of 24 soybean genotypes grown during 1980 at two locations (Test 1980, A-3).

\begin{tabular}{lrrr}
\hline \hline Source & d.f. & Tapachula & Boliche \\
\hline Replications & 2 & 11.58 & 4.64 \\
Genotypes & 23 & 47.03 & $24.53^{*}$ \\
Error & 46 & 29.53 & 8.22 \\
Yield Mean & & 3046 & 1324 \\
C.v. & & 17.84 & 21.66 \\
\end{tabular}

Indicates significance at the $1 \%$ level. 


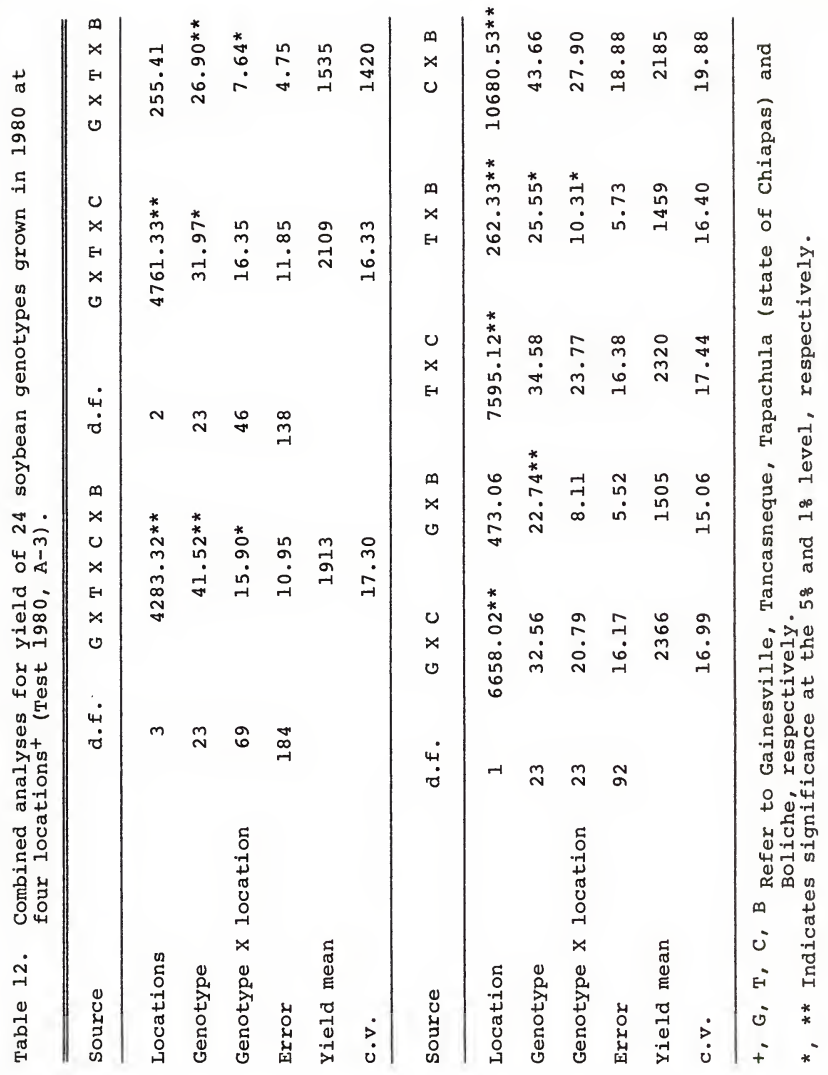


In all nine location combinations studied, a significant genotype $\mathrm{x}$ location interaction was found only when both the Tancasneque (T) and the Boliche (B) locations were included. These two locations evidently represent the most extreme difference in relative performance of the 24 genotypes because interactions were not significant when data from either of these locations were used in combined analyses with data from either Gainesville (G) or Tapachula (C).

All possible two-location combinations were analyzed, but one combination of more than two locations was not analyzed. Analyses performed indicate that if either the Tancasneque or the Boliche location had been deleted, there would have been no genotype $x$ location interaction.

Yield means ( $\mathrm{kg} / \mathrm{ha}$ ) at the four locations were: Tapachula, 3046; Gainesville, 1686; Tancasneque, 1594; and Boliche, 1324. One might expect that locations having the largest differences in mean yield would have the largest genotype $\mathrm{x}$ location interaction. This was not true here. Tancasneque and Boliche had the lowest mean yields. The Boliche plots were under drought stress for a 24-day period during flowering. This contributed to the low yield, but its effect on the genotype $x$ location interaction is unknown. The primary purpose of this experiment, however, was to determine if selection at Gainesville can improve performance of soybean genotypes grown at tropical locations. The absence of a significant genotype $\mathrm{x}$ location interaction in all three location combinations involving Gainesville suggests that 
such selection would be more likely to have a positive than a negative effect.

$1979, \mathrm{~A}-2 ; 1980, \mathrm{~A}-4$

The second group of plant rows selected at both Gainesville and Tancasneque in 1978 (Table 2) was evaluated in 1979 as test A-2, and reduced in number for 1980 evaluation in test $\mathrm{A}-4$.

Table 13 shows mean squares from yield analyses at Gainesville and at Tancasneque in 1979. The 40 genotype means were significantly different at the 0.01 and 0.05 levels at Gainesville and Tancasneque, respectively (Table 13). At Gainesville and at Tancasneque, neither Jupiter nor UFV-1 differed from the mean of the 38 test lines.

The mean of Gainesville and Tancasneque selections did not differ significantly at either location. This suggests that initial selection at each location did not improve the yield potential for either location. The reasons selection was not effective at either location may include different environmental conditions in 1978 (year when the selection was made) and 1979 (year of evaluation); and possibly a wide range of adaptation for these selected lines. Detailed data on all lines at both locations are given in Appendix Tables 5 and 6 .

The mean squares for lines within groups was significant at the 0.01 and 0.05 levels at Gainesville and Tancasneque respectively (Table 13). This indicates that there was variability for yield among test lines at both locations. 
Table 13. Mean squares for yield of 40 soybean genotypes grown during 1979 at two locations (Test 1979, $\mathrm{A}-2$ ).

Location analyses

Source

d.f.

Gainesville

Tancasneque

Genotypes

39

$16.59 * *$

15.56 *

Jupiter vs rest

1

.67

1.09

UFV-1 vs rest

1

2.60

.40

Gainesville vs

Tancasneque selections 1

.03

9.65

Lines within groups

36

$17.88 * *$

16.54 *

Error

39

4.50

8.04

Yield mean

1943

1652

c.v.

10.91

17.16

Combined analyses

Source

d.f.

Gainesville x Tancasneque

Locations

1

$337.50 * *$

Genotypes

39

23.24 **

Genotypes x locations

39

8.90

Error

78

6.27

Yield mean

1798

c.v.

13.92

*, ** Indicates significance at the $5 \%$ and $1 \%$ level, respectively. 
Table 13 also gives mean squares for the combined analysis. There was a highly significant genotype effect over locations, but the genotype $\mathrm{x}$ location interaction was not significant. The 21 lines selected for retesting in 1980 are listed in Table 14. Selected lines included those performing best at Gainesville, at Tancasneque, and at both locations. Ten and 11 selected lines were Tancasneque and Gainesville selections, respectively. Jupiter, UFV-1, and F75-9207 were added as checks to make 24 entries. Tests were grown in 1980 at Gainesville, Tancasneque, Tapachula, and Boliche.

Table 15 shows mean squares from yield analyses of data from Gainesville, Tancasneque, Tapachula, and Boliche. The 24 genotype means were significantly different at the 0.01 level at Tancasneque and Tapachula but nonsignificant at Gainesville and Boliche. Detailed data on all genotypes at the four locations are given in Tables 7 and 8 of the Appendix.

The mean squares for genotype $x$ location interactions are of particular interest. Nine of the 10 possible location combinations were analyzed. Five of the nine genotype $x$ location interactions were significant. All five included some combination of Tancasneque with Tapachula ( T X C) or Tancasneque with Boliche ( $T$ X B). For purposes of this experiment, it is important to note that no two-location interaction involving Gainesville was significant. It is also important that genotype means were significantly different at the 0.01 level in six combined analyses, at the 
Table 14. Mean yield of 21 soybean genotypes from Test 1979 , A-2, which were selected for retesting (in 1980) in $\mathrm{kg} / \mathrm{ha}$, rank, and as percent of overall mean.

\begin{tabular}{|c|c|c|c|c|c|c|}
\hline & $\begin{array}{c}\text { Gain } \\
\text { yield } \\
\text { in } \\
\mathrm{kg} / \mathrm{ha}\end{array}$ & $\begin{array}{c}\text { ville } \\
\text { Rank } \\
\text { no. }\end{array}$ & $\begin{array}{l}\text { eld } \\
\text { Yield } \\
\text { in } \\
\text { g }\end{array}$ & $\begin{array}{c}\text { Tanc } \\
\text { Yield } \\
\text { in } \\
\mathrm{kg} / \mathrm{ha}\end{array}$ & $\begin{array}{c}\text { neque } \\
\text { Rank } \\
\text { no. }\end{array}$ & $\begin{array}{c}\text { yield } \\
\text { Yield } \\
\text { in } \\
\%\end{array}$ \\
\hline F78-1219 & 1818 & 27 & 94 & 1874 & 8 & 113 \\
\hline F 78-1220 & 1968 & 18 & 101 & 1625 & 19 & 98 \\
\hline F78-1221 & 1756 & 31 & 90 & 2122 & 4 & 128 \\
\hline F78-1236 & 1560 & 37 & 80 & 1833 & 12 & 111 \\
\hline F78-1240 & 1788 & 29 & 92 & 1855 & 10 & 112 \\
\hline F78-1241 & 2305 & 5 & 119 & 1495 & 27 & 90 \\
\hline F 78-1243 & 1913 & 21 & 98 & 1725 & 14 & 104 \\
\hline F78-1246 & 2121 & 10 & 109 & 1162 & 40 & 70 \\
\hline F78-1247 & 2120 & 11 & 109 & 1443 & 32 & 87 \\
\hline F78-1250 & 2651 & 1 & 136 & 1854 & 11 & 112 \\
\hline F78-1251 & 1954 & 19 & 101 & 1997 & 5 & 121 \\
\hline F78-1316 & 2133 & 9 & 110 & 1625 & 18 & 98 \\
\hline F78-1331 & 2335 & 4 & 120 & 2230 & 2 & 135 \\
\hline F78-1347 & 1883 & 23 & 97 & 1873 & 9 & 113 \\
\hline F78-1350 & 2073 & 14 & 107 & 1893 & 7 & 115 \\
\hline F78-1351 & 2367 & 3 & 122 & 1953 & 6 & 118 \\
\hline F78-1373 & 2177 & 7 & 112 & 1743 & 13 & 106 \\
\hline F78-1377 & 2580 & 2 & 133 & 2365 & 1 & 143 \\
\hline F78-1378 & 2262 & 6 & 116 & 1617 & 20 & 98 \\
\hline F78-1469 & 2027 & 16 & 104 & 1714 & 15 & 104 \\
\hline F78-1541 & 2167 & 8 & 112 & 2127 & 3 & 129 \\
\hline
\end{tabular}




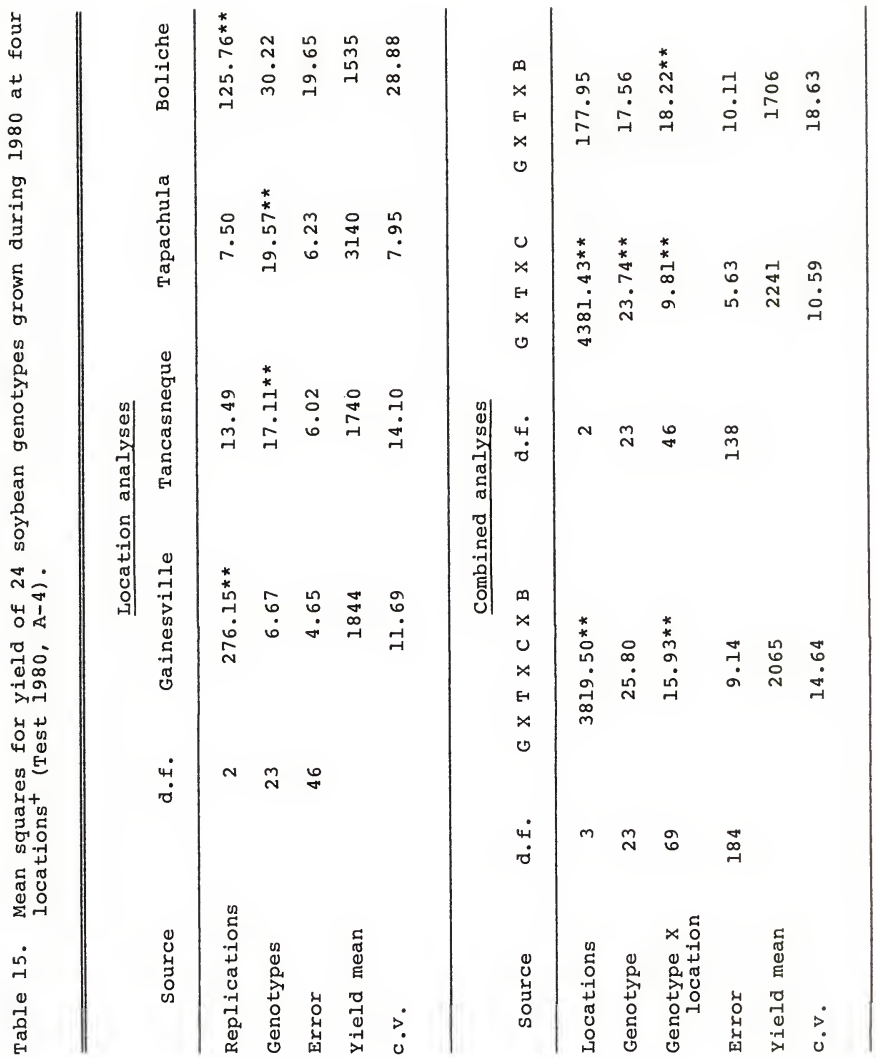




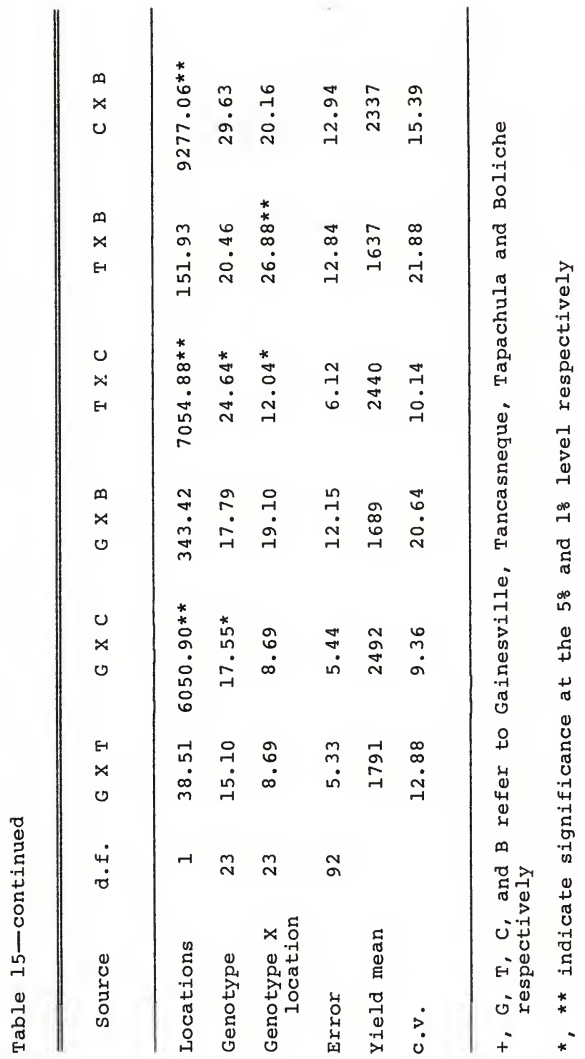


0.05 level in one combination and nonsignificant in only two combinations.

Yield means (kg/ha) at the four locations were: Tapachula, 3140; Gainesville, 1844; Tancasneque, 1740; and Boliche, 1535. Similar results were found in 1980 Test A-3.

The results of Experiment 1 suggest that there is good potential for selecting genotypes adapted to late planting at Gainesville that will have good performance at lower latitudes or in short-day environments. However, agronomic characteristics are very important also, and selection for some of them at Gainesville may improve performance when plants are grown under short-day conditions.

To indicate which traits at Gainesville we need to consider for improving the potential for adaptation at Tancasneque, several correlations of yield with various agronomic characters were carried out. The results are given in Table 16.

Selection for high yield at Gainesville can improve yield at Tancasneque. All four $r$ values were positive. Two were significant.

Within the range of variability represented by these lines, selection for late maturity, tall plants, and wide canopy will likely have a positive effect on yield at Tancasneque. Only one negative $r$ value was obtained and it was low. One-half of all $r$ values for each trait were significantly positive. The range in variation for each trait at both Gainesville and Tancasneque is shown in Table 17. 


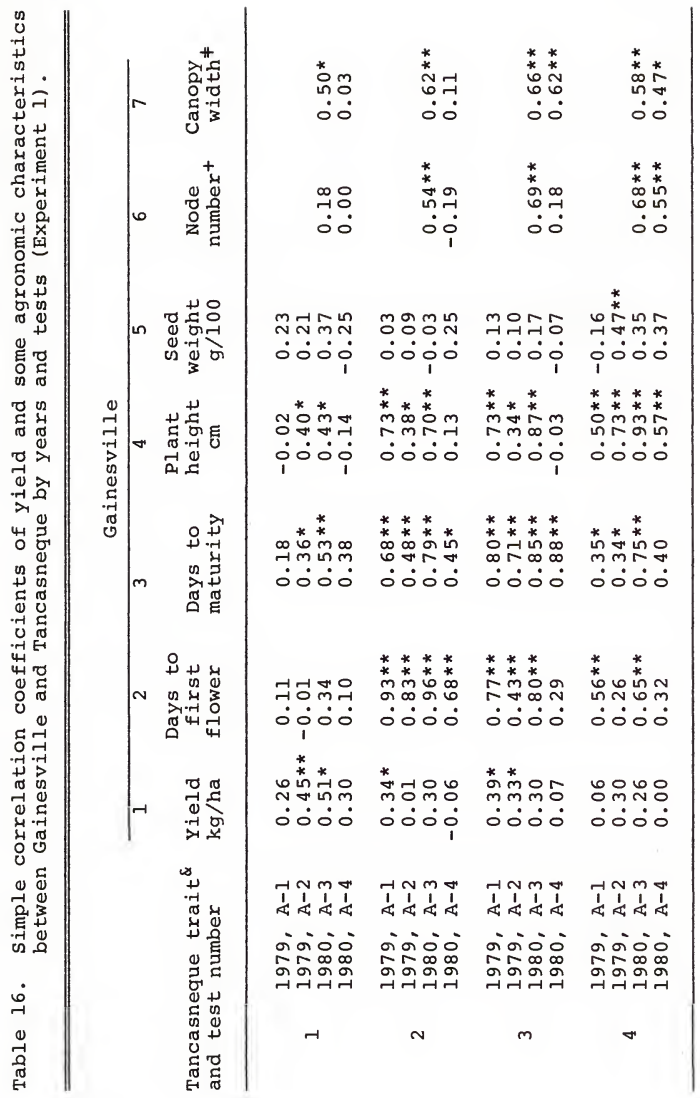




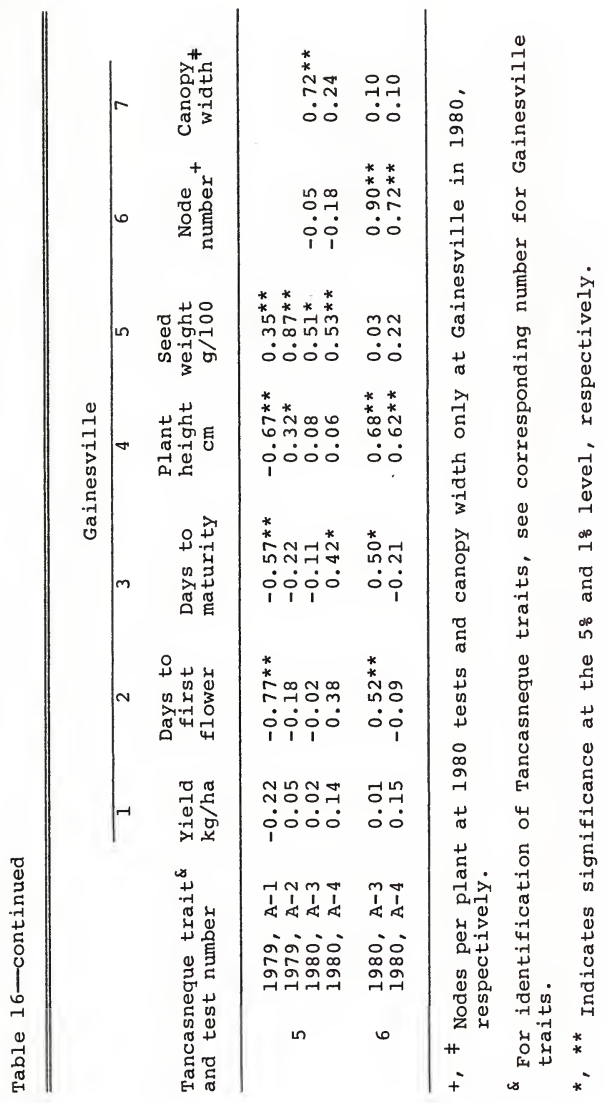




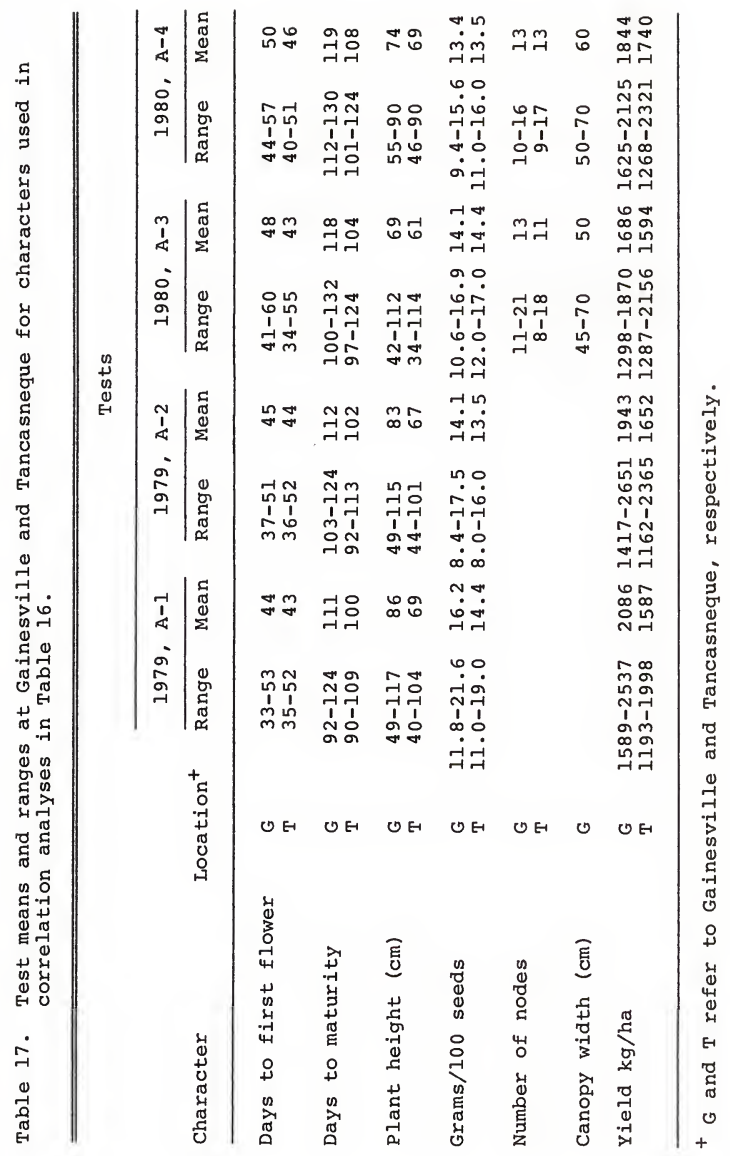


In general, plants at Gainesville had more days to maturity and were taller. Canopy width was not measured at Tancasneque.

Within the range of variability, days to first flower, node number, and grams per 100 seed at Gainesville had a small effect on yield at Tancasneque. Data in Table 17 show that the range in variation in these traits were sufficient to cause significant correlations if they were important.

Because days to maturity was significantly correlated with yield but days to first flower was not, more days from flowering to maturity probably was the important contribution of late maturity.

Some studies indicate significant positive correlations between yield and maturity (Kaw \& Menon, 1972; Saxena \& Pandey, 1971; Schapaugh \& Wilcox, 1980), but negative correlations are also reported (Teixiera, 1977; Schapaugh \& Wilcox, 1980). Brim (1980) pointed out that correlated responses to date do not appear to provide useful selection criteria for increased yield. The results are inconsistent from cross to cross and over environments.

It is possible, however, to select for characteristics which will increase the capacity of genotypes to yield well. When short plants limit the yielding capacity, for example, it is important to select for taller plants. The same logic prevails for other plant traits. For such selection to be effective, however, the selected trait must have a high heritability. 
The heritability of the various traits measured in this study can be inferred from correlations between the same trait at the two locations. High positive $r$ values indicate high heritabilities. Approximate heritability ranks are days to first flower $>$ days to maturity $=$ node number $>$ plant height > grams/100 seed > yield. Inferred heritabilities are high enough to merit selection for any character having a significantly positive correlation with yield.

\section{Experiment 2}

\section{Evaluation}

The 42 lines selected in 1977 were divided in two sets of 22 and 20 lines. Jupiter and UFV-1 were added as checks to make 24 and 22 entries per test. Tests are identified as 1978, B-1 and 1978, B-2. Genotypes were evaluated at Gainesville and Tancasneque. Table 17 shows mean squares for yield analyses.

In Test B-1 at Gainesville, there were significant yield differences among the 22 test lines, but the mean of the test lines did not differ significantly from either Jupiter or UFV-1. At Tancasneque, no significant difference among test lines was detected. However, the mean of the test lines was significantly less than Jupiter $(\underline{P}<0.05)$ and UFV-1 $(\underline{p}<0.01)$.

In the combined analysis for Test B-1, genotype means over both locations did not differ significantly, but there was a highly significant genotype $x$ location interaction. 


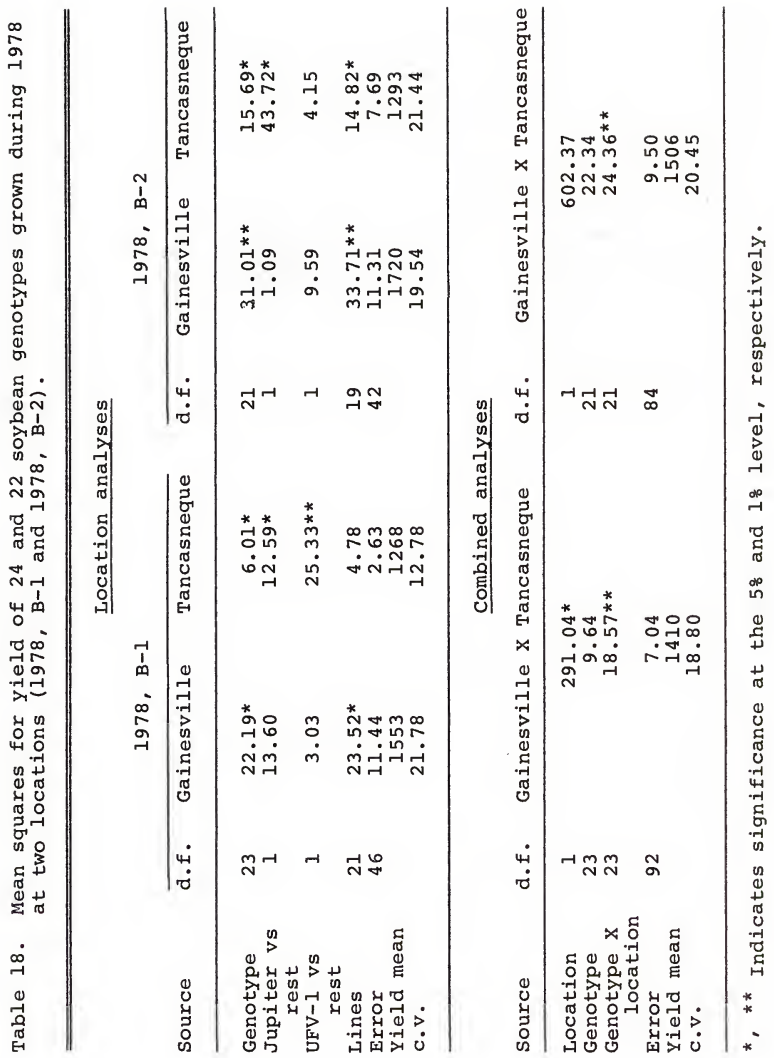


Test B-2 showed some similarities and some differences. At Gainesville, the 20 line means differed $(\underline{p}<0.01)$, but the mean of these 20 lines did not differ significantly from either Jupiter or UFV-1. At Tancasneque, the line means differed $(\underline{0}<0.05)$, and the mean of the 20 lines was significantly below Jupiter but not UFV-l.

In the combined analysis, the means of the genotypes over both locations were not significantly different (locations considered random), but the genotype $x$ location interaction was significant at 0.01 .

Considering both tests, all four genotype mean squares were significant and one was significant at 0.01 . However, in combined analyses, neither genotype mean square was significant because the relative performance of many genotypes at the two locations differed, as is indicated by highly significant genotype $\mathrm{x}$ location interactions.

These results suggest that selection at Gainesville (for yield) is not likely to improve yield at Tancasneque. However, examination of individual line means (Appendix Tables 9 and 11) gives evidence that a few lines yielded equal to or better than check cultivars at both locations. Evidence for this can also be seen in Tables 19 and 20, particularly Table 19.

Table 19 identifies lines which contributed little to the genotype $\mathrm{x}$ location interaction and Table 20 identifies genotypes which contributed most. This procedure was described in the Experiment 1 discussion. Jupiter and UFV-1 were in the 
Table 19. Mean yield of 11 and 10 soybean genotypes from Tests 1978, B-1 and B-2 respectively, which contributed little to the genotype $\mathrm{X}$ location interaction in $\mathrm{kg} / \mathrm{ha}$, rank, and as percent of overall test mean.

\begin{tabular}{|c|c|c|c|c|c|c|}
\hline \multirow[b]{3}{*}{ Cultivar } & \multirow{2}{*}{\multicolumn{3}{|c|}{ Gainesville yield }} & \multirow{2}{*}{\multicolumn{3}{|c|}{ Tancasneque yield }} \\
\hline & & & & & & \\
\hline & $\begin{array}{c}\text { Yield } \\
\text { in } \\
\mathrm{kg} / \mathrm{ha}\end{array}$ & $\begin{array}{c}\text { Rank } \\
\text { no. }\end{array}$ & $\begin{array}{l}\text { Yield } \\
\text { in } \\
\frac{8}{8}\end{array}$ & $\begin{array}{l}\text { Yield } \\
\text { in } \\
\mathrm{kg} / \mathrm{ha}\end{array}$ & $\begin{array}{c}\text { Rank } \\
\text { no. }\end{array}$ & $\begin{array}{c}\text { Yield } \\
\text { in } \\
8\end{array}$ \\
\hline F76-7145 & 1497 & 14 & 96 & 1220 & 14 & 96 \\
\hline F76-7376 & 1459 & 17 & 94 & 1221 & 13 & 96 \\
\hline F 76-6728 & 1590 & 10 & 102 & 1341 & 7 & 106 \\
\hline F76-6854 & 1533 & 12 & 99 & 1210 & 16 & 95 \\
\hline F76-6724 & 1350 & 20 & 87 & 1171 & 19 & 92 \\
\hline F76-7205 & 1471 & 15 & 95 & 1146 & 20 & 90 \\
\hline F76-7323 & 1648 & 7 & 106 & 1403 & 4 & 111 \\
\hline F76-7298 & 1554 & 11 & 100 & 1173 & 18 & 93 \\
\hline F76-7215 & 1792 & 3 & 115 & 1357 & 6 & 107 \\
\hline F 76-7295 1 & 1752 & 6 & 113 & 1329 & 8 & 105 \\
\hline F76-7351 1 & 1640 & 9 & 106 & 1243 & 12 & 98 \\
\hline Test mean & 1553 & & 100 & 1268 & & 100 \\
\hline
\end{tabular}


Table 19-continued

\begin{tabular}{|c|c|c|c|c|c|c|}
\hline \multirow[b]{2}{*}{ Cultivar } & \multicolumn{3}{|c|}{ Gainesville yield } & \multicolumn{3}{|c|}{ Tancasneque yield } \\
\hline & $\begin{array}{l}\text { Yield } \\
\text { in } \\
\mathrm{kg} / \mathrm{ha}\end{array}$ & $\begin{array}{c}\text { Rank } \\
\text { no. }\end{array}$ & $\begin{array}{c}\text { Yield } \\
\text { in } \\
8\end{array}$ & $\begin{array}{l}\text { Yield } \\
\text { in } \\
\mathrm{kg} / \mathrm{ha}\end{array}$ & $\begin{array}{c}\text { Rank } \\
\text { no. }\end{array}$ & $\begin{array}{c}\text { Yield } \\
\text { in } \\
8\end{array}$ \\
\hline F74-3491 & 1499 & 18 & 87 & 1110 & 19 & 86 \\
\hline F 75-92071 & 2051 & 2 & 119 & 1549 & 4 & 120 \\
\hline F 76-6570 & 1432 & 19 & 83 & 1112 & 18 & 86 \\
\hline F76-9967 & 1692 & 15 & 98 & 1304 & 12 & 101 \\
\hline F 76-6875 & 1848 & 9 & 107 & 1330 & 9 & 103 \\
\hline F $76-7233^{1}$ & 1835 & 10 & 107 & 1435 & 6 & 111 \\
\hline F $76-7236^{1}$ & 1923 & 6 & 112 & 1366 & 8 & 106 \\
\hline F74-2716 & 1609 & 16 & 94 & 1326 & 11 & 103 \\
\hline F 76-0002 & 1694 & 14 & 98 & 1150 & 16 & 89 \\
\hline F 75-9209 & 1968 & 5 & 114 & 1329 & 10 & 103 \\
\hline Test mean & 1720 & & 100 & 1293 & & 100 \\
\hline
\end{tabular}

1 Lines selected for retesting in 1979 and 1980, relatively good at both locations. 
Table 20. Mean yield of 9 and 12 soybean genotypes from Tests $1978, \mathrm{~B}-1$ and $\mathrm{B}-2$ respectively, which contributed most to the genotype $\mathrm{X}$ location interaction in $\mathrm{kg} / \mathrm{ha}$, rank, and as percent of overall test mean.

\begin{tabular}{|c|c|c|c|c|c|c|}
\hline \multirow[b]{3}{*}{ CuItivar } & \multicolumn{3}{|c|}{$1978, \mathrm{~B}-1$} & \multirow{2}{*}{\multicolumn{3}{|c|}{ Tancasneque yield }} \\
\hline & \multicolumn{3}{|c|}{ Gainesville yield } & & & \\
\hline & $\begin{array}{c}\text { Yield } \\
\text { in } \\
\mathrm{kg} / \mathrm{ha}\end{array}$ & $\begin{array}{r}\text { Rank } \\
\text { no. }\end{array}$ & $\begin{array}{c}\text { Yield } \\
\text { in } \\
\text { o }\end{array}$ & $\begin{array}{c}\text { Yield } \\
\text { in } \\
\mathrm{kg} / \mathrm{ha}\end{array}$ & $\begin{array}{r}\text { Rank } \\
\text { no. }\end{array}$ & $\begin{array}{c}\text { Yield } \\
\text { in } \\
8\end{array}$ \\
\hline F 76-7087 2 & 2301 & 1 & 148 & 1043 & 24 & 82 \\
\hline F76-6858 & 887 & 24 & 57 & 1321 & 9 & 104 \\
\hline F76-6938 3 & 1422 & 19 & 92 & 1599 & 1 & 126 \\
\hline Jupiter & 1348 & 21 & 87 & 1457 & 3 & 115 \\
\hline UFV-1 & 1463 & 16 & 94 & 1544 & 2 & 122 \\
\hline F $76-7095^{2}$ & 1931 & 2 & 124 & 1215 & 15 & 96 \\
\hline$F 76-6719^{2}$ & 1765 & 4 & 114 & 1113 & 21 & 88 \\
\hline F76-7162 & 1161 & 23 & 75 & 1283 & 11 & 101 \\
\hline F76-7336 & 1761 & 5 & 113 & 1100 & 22 & 87 \\
\hline Test mean & 1553 & & 100 & 1243 & & 100 \\
\hline
\end{tabular}


Table 20-continued

$$
1978, \mathrm{~B}-2
$$

Gainesville yield

Tancasneque yield

\begin{tabular}{|c|c|c|c|c|c|c|}
\hline Cultivar & $\begin{array}{l}\text { Yield } \\
\text { in } \\
\mathrm{kg} / \mathrm{ha}\end{array}$ & $\begin{array}{c}\text { Rank } \\
\text { no. }\end{array}$ & $\begin{array}{c}\text { Yield } \\
\text { in } \\
8\end{array}$ & $\begin{array}{l}\text { Yield } \\
\text { in } \\
\mathrm{kg} / \mathrm{ha}\end{array}$ & $\begin{array}{c}\text { Rank } \\
\text { no. }\end{array}$ & $\begin{array}{c}\text { Yield } \\
\text { in } \\
8\end{array}$ \\
\hline F76-9835 & 1356 & 21 & 79 & 1695 & 1 & 131 \\
\hline F75-7093 2 & 1914 & 7 & 111 & 782 & 22 & 60 \\
\hline F 76-6554 & 698 & 22 & 41 & 1134 & 17 & 88 \\
\hline F76-0007 & 2183 & 1 & 127 & 1154 & 15 & 89 \\
\hline F76-69283 & 1363 & 20 & 79 & 1495 & 5 & 116 \\
\hline D73-9360 & 1887 & 8 & 110 & 993 & 21 & 77 \\
\hline Jupiter & 1787 & 16 & 104 & 1661 & 2 & 128 \\
\hline F76-6918 & 1969 & 4 & 114 & 1178 & 14 & 91 \\
\hline F76-7452 & 1796 & 11 & 104 & 1041 & 20 & 81 \\
\hline F $76-6883^{3}$ & 1769 & 13 & 103 & 1604 & 3 & 124 \\
\hline UFV-1 & 1542 & 17 & 90 & 1390 & 7 & 108 \\
\hline F76-6884 2 & 2024 & 3 & 118 & 1300 & 13 & 101 \\
\hline Test mean & 1720 & & 100 & 1293 & & 100 \\
\hline
\end{tabular}

2 Lines selected for retesting in 1979 and 1980, good at Gainesville.

3 Lines selected for retesting in 1979 and 1980, good at Tancasneque. 
group considered to contribute most to the interaction in both tests, because of their better performance, relative to test lines, at Tancasneque.

The small contribution to the genotype $\mathrm{X}$ location interaction for lines listed in Table 19 is further illustrated by high correlation coefficients for yield at the two locations for lines in Table $19(r=0.77 * *$ and $r=0.84 * *$ for lines in Test $\mathrm{B}-1$ and $\mathrm{B}-2$, respectively).

Conversely, the large contribution to the interaction is illustrated by negative $r$ values for genotypes listed in Table 20 ( $r=-0.59$ and $r=-0.25$ for Test $B-1$ and $B-2$, respectively).

1979,1980 Evaluations

From the 42 breeding lines in 1978 Tests B-1 and B-2, 22 lines were selected for testing in 1979 and 1980 . In the group selected, nine performed well at both locations, seven performed well at Gainesville only, and four performed well at Tancasneque only. Two more lines and Jupiter and UFV-1 checks were added to make 24 entries. The 1979 and 1980 tests are identified as $\mathrm{B}-3$ and $\mathrm{B}-4$, respectively.

The 1978 tests (B-1 and $B-2$ ) served to refine hypotheses on the feasibility of selecting at Gainesville to improve performance in more tropical environments, represented by Tancasneque in this particular experiment. The highly significant genotype $x$ location interaction for both 1978 tests is evidence that some lines had significantly different relative performances at the two locations. 
The cause of the genotype $\mathrm{x}$ location interaction appeared to be associated more with differential responses to environmental conditions than to differences in plant characteristics such as height and maturity. This suggests that the latitude difference $\left(29\right.$ vs $\left.23^{\circ}\right)$ was relatively unimportant.

Because soil properties at the two locations differ greatly (sandy soil, low $\mathrm{pH}$, high $\mathrm{P}$, low $\mathrm{K}$ vs clay soil, $\mathrm{pH}$ 8.0, low P, high $\mathrm{K}$ ), this was considered the most probable cause of the highly significant genotype $X$ location interactions. The presence of Fe chlorosis in some 1978 plots at Tancasneque, apparently associated with high soil pH, was considered additional evidence that a differential response to soil properties could have caused the interaction. Another factor could be environmental effects associated with year difference at one location in 1978, but this was not considered seriously in planning 1979 and 1980 tests.

If a differential response to soil properties was the primary cause of the interaction, including seven lines that performed well at Gainesville only, and four lines that performed well at Tancasneque only, in the 1979-80 tests would be expected to result in significant genotype $x$ location interactions in 1979 and 1980. Since both check varieties, Jupiter and UFV-1, tended to be superior at Tancasneque, but not at Gainesville, the high performing entries at Tancasneque is increased to six.

To obtain a better estimate of the extent to which soil 
$\mathrm{pH}$ per se causes differences in relative performance, genotypes in 1979 and 1980 tests (B-3 and B-4) were also evaluated at Tapachula, Mexico (soil pH 5.1) and Boliche, Ecuador (pH 6.7). Although not stated previously, these considerations were the primary reasons for growing Experiment 1 plots in both Tapachula and Boliche in 1980.

Results from 1979 and 1980 tests at Gainesville and Tancasneque will be presented first for two reasons: (a) The experiment was originally planned to compare responses at Gainesville and Tancasneque, and (b) data from Tapachula and Boliche were received after analyses of available data were underway. Results from Tapachula and Boliche will follow.

Table 21 shows mean squares for yield analyses at Gainesville and Tancasneque in 1979 and 1980. The 24 genotype means were significantly different at the 0.01 level at Tancasneque both years, but at Gainesville, differences were not significant. At Tancasneque both Jupiter and UFV-l yielded significantly more than the mean of the 22 test lines in 1979, but not in 1980. This suggests the possibility of a genotype $\mathrm{X}$ year effect at Tancasneque.

Combined analyses by years (Table 21) show no significant genotype effect over locations either year, but a highly significant genotype $\mathrm{x}$ location interaction both years.

Further analyses of these data are presented in Table 22. Combined analyses over years at each location show no significant genotype $x$ year effect at Gainesville, but a highly significant genotype $\mathrm{x}$ year effect at Tancasneque. 


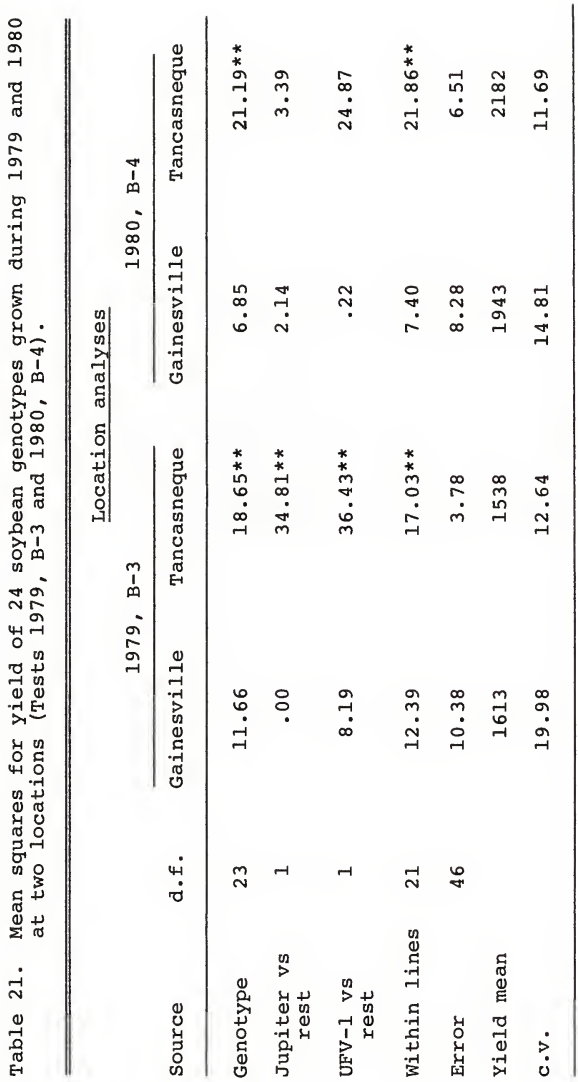




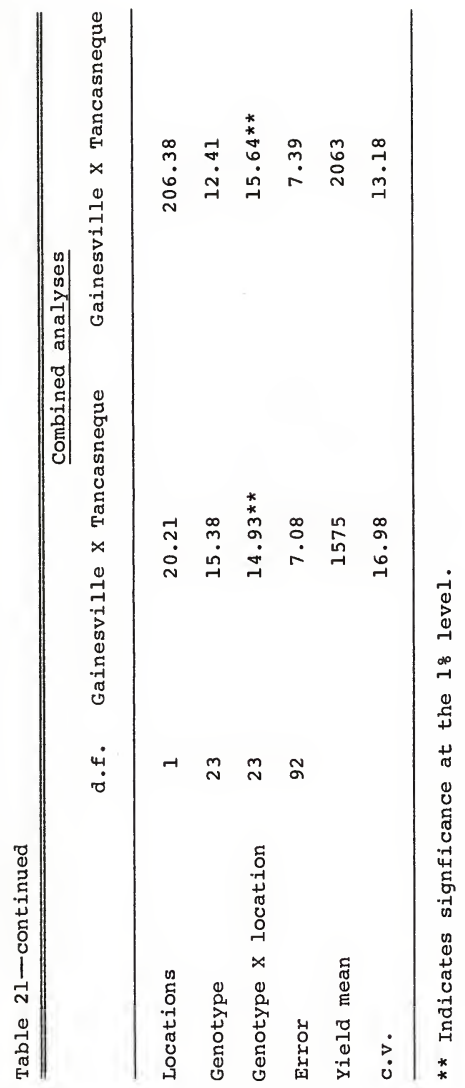


The highly significant genotype $x$ year effect at Tancasneque could be caused by climatic differences, moving plots to a different field, or both. In Mexico, large ecological differences often occur within short distances (Marquez, 1976).

Table 22 also shows mean squares for effects over locations and years. The genotype $\mathrm{x}$ location $\mathrm{x}$ year interaction was not significant, but the genotype $x$ location interaction was significant. LeClerg et al. (1962) state that when the interaction of varieties $\mathrm{x}$ locations significantly exceeds varieties $x$ locations $x$ years, it is clear that the differential response of the varieties at the individual locations was sufficiently similar in the different years to warrant the conclusion that these differential responses may be permanent features for these locations.

The following conclusions seem appropriate based on LeClerg's statement and on the data in Tables 21 and 22.

1. The 24 genotypes performed similarly at Gainesville in both 1979 and 1980, but differently at Tancasneque both years.

2. Genotypic differences at Tancasneque over years persisted despite the significant genotype $\mathrm{x}$ year interaction.

3. A significant amount of the genotype $x$ location interaction each year is a permanent feature of the two environments.

4. The differential location response results from nearly equal performance of the 24 genotypes at Gainesville and 
Table 22. Mean squares for yield of 24 soybean genotypes grown during two years at two locations.

\begin{tabular}{lrrr}
\hline & & \multicolumn{2}{c}{ Combined analyses for years at each location } \\
\cline { 3 - 4 } Source & d.f. & Gainesville $1979 \times 1980$ & Tancasneque $1979 \times 1980$ \\
\hline Year & 1 & 392.87 & $1496.27^{*}$ \\
Genotype & 23 & 9.16 & $26.61 *$ \\
$\begin{array}{l}\text { Genotype } \\
\text { year }\end{array}$ & 23 & 9.36 & $13.23^{*}$ \\
Error & 92 & 8.98 & 5.14 \\
Yield mean & 1778 & 1860 \\
c.v. & 16.86 & 12.19 \\
\hline
\end{tabular}

Combined analyses over locations and years

Source d.f.

Year

Location

Year X location

Replications within location and years

Genotype

Genotype $\mathrm{x}$ year

Genotype x location

Genotype x location X year

Pooled error

184

Yield mean

c.v.
1

1

1

8

23

23

23

23

1819

14.79

*, ** Indicates significance at the $5 \%$ and $1 \%$ level, respectively. 
unequal performance at Tancasneque.

Conclusion 3 above was based primary on LeClerg's statement, but it is supported by the significant genotype effect over years at Tancasneque, tested against the genotype $x$ year interaction (Table 22). However, using the procedure from stuber et al. (1973), we attempted to determine if genotypes tended to be consistent in their yield relationship between locations over years. Yield of each genotype was expressed as percentage of each test mean as before. Genotypes are listed in Table 23 in order from smallest to largest difference in percentage values between locations. The left side of Table 23 lists the order for 1979; the right side for 1980. We found no consistency in the listings. As before, genotypes with small differences in percentage yield were considered to contribute little to the genotype $x$ location interaction for that year. Those with large differences were considered to contribute most. So far as we could determine from data in Table 23, the group of genotypes contributing most to the genotype $x$ location in 1979 was nearly random, relative to the group contributing most in 1980 . Further the seven lines selected in 1978 for good performance at Gainesville only and the four lines selected for good performance at Tancasneque only seemed to appear at random in the 1979 and 1980 listings. These observations suggest that in addition to the "permanent feature of the environment" stated in conclusion 3, a significant amount of variation associated with other effects remains. These other effects are presumed to be 
Table 23. Mean yield of 24 soybean genotypes grown during 1979 and 1980 at two locations in $\mathrm{kg} / \mathrm{ha}$, rank, and as percent of overall test mean.

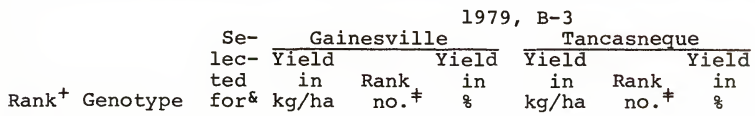

\begin{tabular}{rlllrrrrr}
1 & F76-6719 & 2 & 1622 & 12 & 101 & 1576 & 11 & 102 \\
2 & F76-6728 & 1 & 1455 & 21 & 90 & 1355 & 18 & 88 \\
3 & F76-7000 & & 1675 & 10 & 104 & 1649 & 8 & 107 \\
4 & F76-9835 & 3 & 1811 & 4 & 112 & 1769 & 5 & 115 \\
5 & F76-6928 & 3 & 1542 & 17 & 96 & 1583 & 10 & 103 \\
6 & F76-7113 & & 1616 & 13 & 100 & 1426 & 15 & 93 \\
7 & F75-9207 & 1 & 1634 & 11 & 101 & 1437 & 14 & 93 \\
8 & UFV-1 & & 1775 & 6 & 110 & 1865 & 3 & 121 \\
9 & F76-6918 & 2 & 1702 & 9 & 106 & 1446 & 13 & 94 \\
10 & F76-7295 & 1 & 1490 & 19 & 92 & 1592 & 9 & 104 \\
11 & F76-6884 & 2 & 1770 & 7 & 110 & 1889 & 2 & 123 \\
12 & F76-7215 & 1 & 1463 & 20 & 91 & 1198 & 24 & 78 \\
13 & F76-6883 & 3 & 1260 & 23 & 78 & 1411 & 16 & 92 \\
14 & F76-7323 & 1 & 1607 & 14 & 100 & 1315 & 19 & 86 \\
15 & F76-7351 & 1 & 1540 & 18 & 95 & 1672 & 7 & 109 \\
16 & Jupiter & & 1602 & 15 & 99 & 1857 & 4 & 121 \\
17 & F76-7095 & 2 & 1931 & 1 & 120 & 1488 & 12 & 97 \\
18 & F76-7087 & 2 & 1723 & 8 & 107 & 1288 & 20 & 84 \\
19 & F76-0007 & 2 & 1085 & 24 & 67 & 1388 & 17 & 90 \\
20 & F75-9209 & 1 & 1784 & 5 & 111 & 1273 & 21 & 83 \\
21 & F76-6938 & 3 & 1370 & 22 & 85 & 1758 & 6 & 114 \\
22 & F76-7236 & 1 & 1839 & 3 & 114 & 1252 & 22 & 81 \\
23 & F75-7093 & 2 & 1855 & 2 & 115 & 1251 & 23 & 81 \\
24 & F76-7233 & 1 & 1551 & 16 & 96 & 2164 & 1 & 141 \\
Test & mean & & 1613 & & 100 & 1538 & & 100 \\
\hline
\end{tabular}

+ Rank from smallest to largest yield deviations between locations expressed as percentage of test mean.

\# Rank from highest to lowest mean yield at each location.

\& Lines selected in 1978 for good performance at Gainesville (2), at Tancasneque (3), or both locations (1). 
Table 23-extended

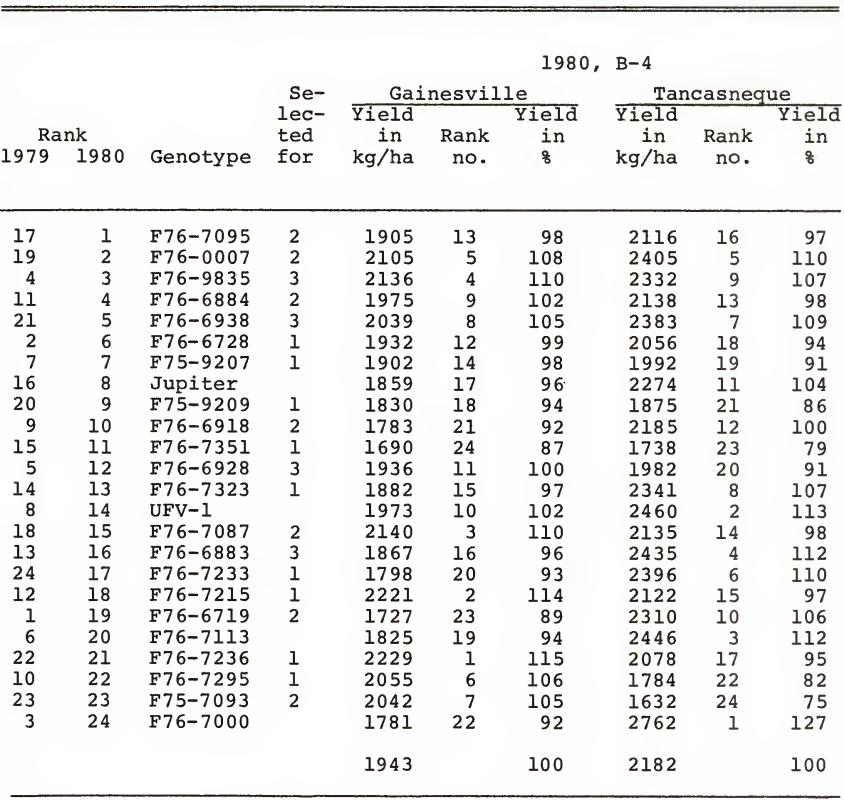


primarily due to inconsistent performance of genotypes at Tancasneque from year to year.

The evidence that differential responses between Gainesville and Tancasneque may be permanent features for these locations is evidence that rigid selection for yield at Gainesville will not necessarily improve yield at Tancasneque. However, there is about as much evidence that rigid selection for yield at Tancasneque in 1979 would not have improved relative yield in 1980. At this point it appears that a modest level of selection for yield at Gainesville would be as likely to be beneficial as detrimental.

Table 24 presents correlation coefficients between various combinations of characters measured from 1978 through 1980. Of the 18 correlation coefficients calculated between characteristics measured at Gainesville and yield at Tancasneque, only one was significant. However there was variation among lines for all agronomic traits measured. The absence of more significant correlations between agronomic characteristics and yield does not mean that agronomic characteristics have no effect on yield. It only means that initial selection included the proper range in days to first flower, days to maturity, and plant height. If cultivars adapted to southern U.S. had been included, positive correlation coefficients would have been expected between yield at Tancasneque and days to first flower, plant height, and maturity at Gainesville.

Correlations among plant height, days to maturity, and 
Table 24. Simple correlation coefficients of yield and some agronomic characteristics between Gainesville and Tancasneque by years and tests (Experiment 2).

\begin{tabular}{|c|c|c|c|c|c|c|}
\hline & & & & inesville & & \\
\hline & & 1 & 2 & 3 & 4 & 5 \\
\hline $\begin{array}{l}\text { Tancas } \\
\text { and te }\end{array}$ & $\begin{array}{l}\text { eque trait } \\
t \text { number }\end{array}$ & $\begin{array}{l}\text { Yield } \\
\mathrm{kg} / \mathrm{ha}\end{array}$ & $\begin{array}{l}\text { Days to } \\
\text { first } \\
\text { flower }\end{array}$ & $\begin{array}{l}\text { Days to } \\
\text { maturity }\end{array}$ & $\begin{array}{l}\text { Plant } \\
\text { height } \\
\mathrm{cm}\end{array}$ & $\begin{array}{l}\text { Seed } \\
\text { weight } \\
\text { g/100 }\end{array}$ \\
\hline 1 & $\begin{array}{ll}1978, & \mathrm{~B}-1 \\
1978, & \mathrm{~B}-2 \\
1979, & \mathrm{~B}-3 \\
1980, & \mathrm{~B}-4\end{array}$ & $\begin{array}{r}-0.39 \\
-0.05 \\
0.01 \\
-0.13\end{array}$ & $\begin{array}{r}0.07 \\
0.37 \\
0.36 \\
-0.01\end{array}$ & $\begin{array}{l}0.04 \\
0.52 * \\
0.40 \\
-0.07\end{array}$ & $\begin{array}{r}-0.02 \\
0.30 \\
0.32 \\
-0.37\end{array}$ & $\begin{array}{r}0.19 \\
-0.38\end{array}$ \\
\hline 2 & $\begin{array}{ll}1978, & \mathrm{~B}-1 \\
1978, & \mathrm{~B}-2 \\
1979, & \mathrm{~B}-3 \\
1980, & \mathrm{~B}-4\end{array}$ & $\begin{array}{l}-0.13 \\
-0.13 \\
-0.33 \\
-0.27\end{array}$ & $\begin{array}{l}0.89 * * \\
0.91 * * \\
0.93 * * \\
0.86 * *\end{array}$ & $\begin{array}{l}0.76 * \star \\
0.65^{\star \star} \\
0.72^{\star *} \\
0.48^{*}\end{array}$ & $\begin{array}{l}0.30 \\
0.65 * * \\
0.60 * * \\
0.38\end{array}$ & $\begin{array}{l}0.15 \\
0.36\end{array}$ \\
\hline 3 & $\begin{array}{l}1978, \mathrm{~B}-1 \\
1978, \mathrm{~B}-2 \\
1979, \mathrm{~B}-3 \\
1980, \mathrm{~B}-4\end{array}$ & $\begin{array}{r}0.29 \\
-0.25 \\
-0.18 \\
-0.19\end{array}$ & $\begin{array}{l}0.43^{*} \\
0.60 * * \\
0.68 * * \\
0.51 *\end{array}$ & $\begin{array}{l}0.78 * * \\
0.73 * * \\
0.77 * * \\
0.78 * *\end{array}$ & $\begin{array}{l}0.35 \\
0.27 \\
0.38 \\
0.35\end{array}$ & $\begin{array}{r}0.00 \\
-0.19\end{array}$ \\
\hline 4 & $\begin{array}{ll}1978, & \mathrm{~B}-1 \\
1978, & \mathrm{~B}-2 \\
1979, & \mathrm{~B}-3 \\
1980, & \mathrm{~B}-4\end{array}$ & $\begin{array}{r}-0.06 \\
0.23 \\
-0.10 \\
-0.33\end{array}$ & $\begin{array}{l}0.60 * * \\
0.37 \\
0.66 * * \\
0.61 * *\end{array}$ & $\begin{array}{l}0.57 * \star \\
0.48 * \\
0.58 * * \\
0.62 \text { ** }\end{array}$ & $\begin{array}{l}0.62 * * \\
0.63 * * \\
0.77 * * \\
0.53 * *\end{array}$ & $\begin{array}{l}0.33 \\
0.36\end{array}$ \\
\hline 5 & $\begin{array}{l}1979, \mathrm{~B}-3 \\
1980, \mathrm{~B}-4\end{array}$ & $\begin{array}{r}0.25 \\
-0.07\end{array}$ & $\begin{array}{l}-0.01 \\
-0.08\end{array}$ & $\begin{array}{c}0.00 \\
-0.48^{*}\end{array}$ & $\begin{array}{r}0.34 \\
-0.07\end{array}$ & $\begin{array}{l}0.41 * \\
0.52 * *\end{array}$ \\
\hline
\end{tabular}

+ For identification of Tancasneque traits, see corresponding number for Gainesville traits.

*, ** Indicates significance at the $5 \%$ and $1 \%$ level, respectively. 
days to first flower are moderately strong, indicating that selection for one of these traits will influence the other two.

Inferences on heritability can be made from the magnitude of the correlation coefficients for the same traits at the two locations. Indicated heritability ranks are days to first flower > maturity date > plant height > grams/100 seed > yield, the same order as indicated for these traits in Experiment 1 (Table 16).

Table 25 shows mean squares for yield analyses at Boliche (1979, B-3 and 1980, B-4) and Tapachula (1980, B-4). The 24 genotype means were significantly different at the 0.01 level at Boliche in 1979 and at the 0.05 level at both locations in 1980. At Boliche both Jupiter and UFV-1 yielded significantly more than the mean of the 22 test lines in 1979, but not in 1980. This suggests the possibility of genotype $X$ year effect at Boliche. Highly significant differences among lines within groups were detected at Boliche in both years. At Tapachula, neither Jupiter nor UFV-l differed from the mean of the 22 test lines. Also, no significant differences among lines within groups existed.

These results illustrate that there is genetic variability for yield among genotypes at both locations. Average yield of some test lines is similar to that of the check varieties. Detailed data on all lines by locations and years are given in Appendix Tables 13 through 16 . 
Table 25. Mean squares for yield of 24 soybean genotypes grown during 1979 (Boliche) and 1980 (Boliche and Tapachula).

\begin{tabular}{|c|c|c|c|c|}
\hline \multirow[b]{3}{*}{ Source } & \multirow[b]{3}{*}{ d.f. } & \multicolumn{2}{|c|}{ Location analyses } & \multirow[b]{2}{*}{ Tapachula } \\
\hline & & \multicolumn{2}{|c|}{ Boliche } & \\
\hline & & $1979, \mathrm{~B}-3$ & $1980, \mathrm{~B}-4$ & $\overline{1980, \mathrm{~B}-4}$ \\
\hline Genotype & 23 & $69.85 * *$ & $26.54 *$ & $29.57 *$ \\
\hline Jupiter vs rest & 1 & $39.08 *$ & 13.59 & 27.10 \\
\hline UFV-1 vs rest & 1 & $35.76 *$ & .23 & 55.30 \\
\hline Within lines & 21 & $72.94 * *$ & $28.40 * *$ & 28.46 \\
\hline Error & 46 & 8.44 & 10.61 & 16.28 \\
\hline Yield mean & & 2259 & 1472 & 3133 \\
\hline$c \cdot v \cdot$ & & 12.86 & 22.12 & 12.88 \\
\hline
\end{tabular}

*, ** Indicates signficance at the $5 \%$ and 18 level, respectively. 
Since these tests were also carried out in 1979 and 1980 at Gainesville and Tancasneque, the mean squares for the interactions among the seven environments are of particular interest. Therefore, further analyses were done considering all possible combinations among years and 1ocations. The results are given in Table 26 . The genotype $\mathrm{x}$ environment interaction was significant in 18 of $21 \mathrm{com}-$ bined analyses.

The genotype $x$ year interaction was not significant for the Gainesville location, but was highly significant for both Tancasneque and Boliche (Table 26). Therefore, each test year at both Tancasneque and Boliche represents distinctly different environments.

There is little evidence from $F$ values in Table 26 that performance at Tancasneque in 1979 predicted performance at Tancasneque in 1980 any better than performance in Gainesville in either year predicted performance at Tancasneque either year. The $\mathrm{F}$ value for the genotype $\mathrm{X}$ environment interaction for Tancasneque 1979 vs 1980 was 2.57**. For Gainesville 1979 vs Tancasneque 1979 and 1980, the $\mathrm{F}$ values were $2.11^{* *}$ and $2.38^{* *}$, respectively. For Gainesville 1980 vs Tancasneque 1979 and 1980, values were $2.71 * *$ and $2.12 * *$, respectively. Similar relationships existed for Boliche and Gainesville.

Considering the significance level and magnitude of all values in Table 26 , it appears that each environment 
Table 26. Significance and $F$ values for genotypes $x$ environment interactions in 21 combined analyses of 24 soybean genotypes grown at four locations in 1979 and 1980 .

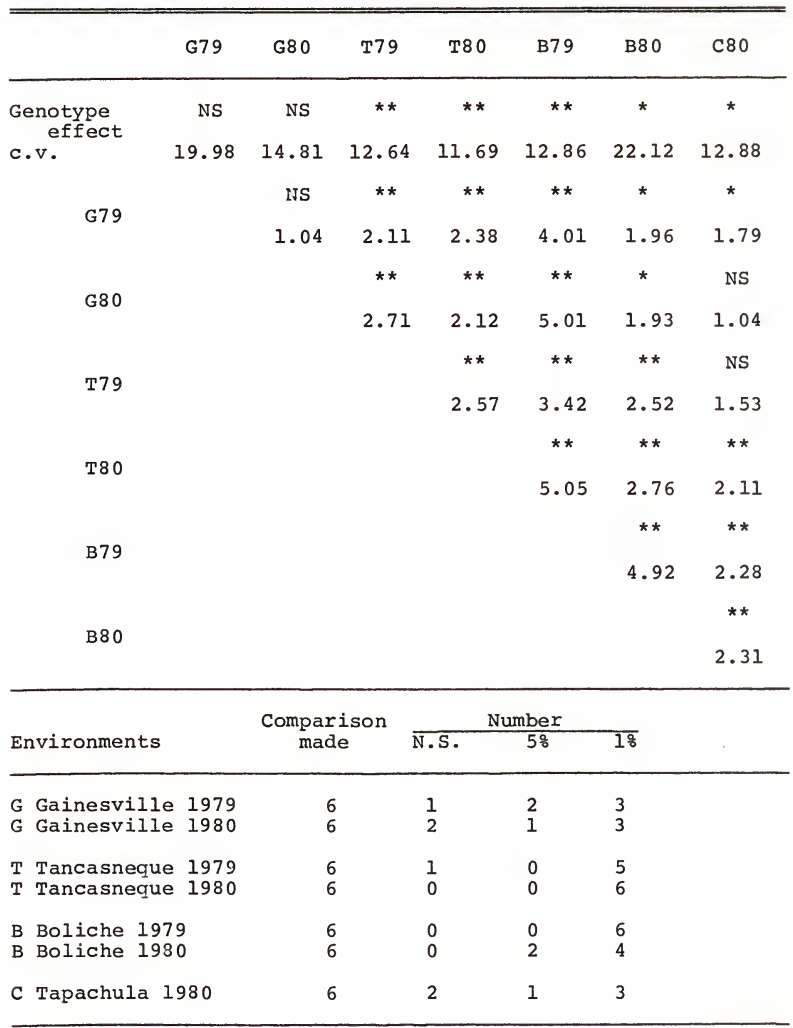


predicted relative performance in all other environments in the following order: Tapachula $80 \geq$ Gainesville $80 \geq$ Gainesville $79 \geq$ Tancasneque $79 \geq$ Boliche $80 \geq$ Tancasneque $80 \geq$ Boliche 79 .

Data in Table 26 indicate considerably different responses from location to location, and also from year to year at Tancasneque and Boliche. The two Gainesville environments, which were not significantly different from each other, were among the best predictors of all other environments.

Table 27 gives yield for each genotypes at each location expressed as percent of the test mean for that particular location. These data are useful for estimating stability over environments or identifying genotypes which have unusual performance trends.

Some genotypes were very stable over environments. The standard deviations (Table 26) suggest that F76-6728, UFV-1, F76-6918, and F76-6884 were more stable than other genotypes. Except for one unusally high or low yield, F76-6928, F76-76-7095, and F76-9835 would have been included.

Genotypes with the highest mean yield over all environments tended to be more stable across environments, but there were exceptions. When two genotypes (F76-7233 and F76-6728) were eliminated from the array of means and standard deviations (Table 27) the correlation coefficient 
욱 옥

.

(⿻)丨

व $\pi$

空

पै

斁

c

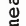

$+$

on

$\stackrel{1}{+}$

$\stackrel{4}{+1}$

4

$\stackrel{4}{\mathrm{C}}$

잉

¿

م. 0

or

(1)

0

of

م.

पु

(1)

or

范

๑

त्र

도

N

H

$+$

o

(4)

근

c.

空

号

$\pi$

로

U

\%

里

E

40

క

'

ח

Uิ

ช

a

สั

다

0

$-1 \infty$

ना

?

on

¿

-

๙ 0

$\cup \sqcap$

$\infty$ N $\infty$ मी

. . . . . . . . . . . . . . न

- 0 m $\infty \pi$ m

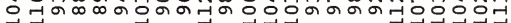

ต

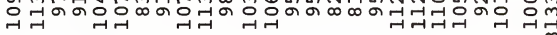

6 ต $6 m$ ザ

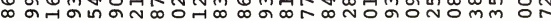

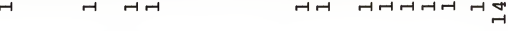

ก N

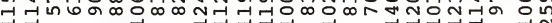

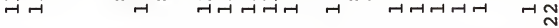

4m

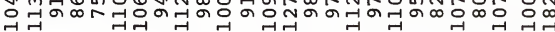

H

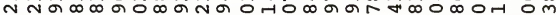

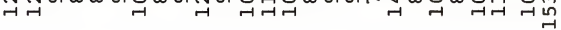

เ

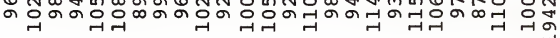

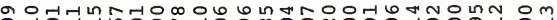

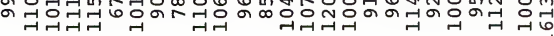

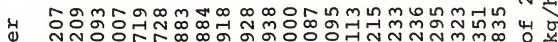
- 1 1

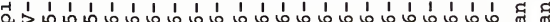
J

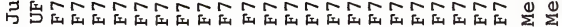


between means and standard deviations is $r=-0.56 *$ * However, with F76-7233 and F76-6728 r=-0.15. F76-7233 was relatively poor at Gainesville but very good in nearly all tropical environments.

When all points are considered, it appears that very rigid selection for performance at Gainesville will eliminate some genotypes which perform well at low latitudes (F76-7233 for example), but that a modest level of selection would be beneficial. The latter would tend to eliminate types with generally low performance in all environments. 
SUMMARY AND CONCLUSIONS

Experiments were conducted to measure relative performance of soybean genotypes planted in mid-July at Gainesville, Florida, U.S.A., and in tropical environments. Relative performance between Gainesville and Tancasneque, Tamaulipas, Mexico (22。 $13^{\prime} \mathrm{N}$-latitude) was emphasized. The purpose was to determine the extent to which selection at Gainesville would affect performance in tropical environments.

Initial plant material was in two developmental stages. In Experiment 1, individual plants selected at Gainesville in 1977 were advanced in plant rows at both Gainesville and Tancasneque in 1978. Breeding lines established from selected rows at both locations provided material for replicated trials in 1979 and 1980. In Experiment 2, breeding lines which had survived preliminary yield tests at Gainesville were chosen.

Seed yields in tropical environments of ten equalled or exceeded seed yield at Gainesville. In nearly all environments, there were significant yield differences among genotypes.

In Experiment 1, few genotype $x$ location interactions were significant, indicating that relative performance in one environment was a good indicator of relative performance in other environments. 
Genotype $\mathrm{X}$ environment interactions in Experiment 2 indicated much more inconsistent performance among genotypes, not only among locations, but also between years at Tancasneque and Boliche. The two Gainesville environments were among the more reliable indicators of overall yield performance.

Environments included locations at $29^{\circ} 30^{\prime}, 22^{\circ} 13^{\prime}$, and $14^{\circ} 59^{\prime} \mathrm{N}$-latitude and $2^{\circ} 15^{\prime} \mathrm{S}$-latitude. The generally good agreement in relative performance between Gainesville $129^{\circ}$ $\left.30^{\prime \prime}\right)$ and Tapachula (14 $\left.{ }^{\circ} 5^{\prime}\right)$ suggests that latitude effects were relatively unimportant in this study.

Results from Experiment 1 indicate that selections at Gainesville would improve performance in tropical environments. Results from Experiment 2 are less encouraging. One of the better performing lines in nearly all tropical environments would have been discarded if very rigid selection for yields had been practiced at Gainesville.

Although lines in Experiment 2 had undergone more rigid selection at Gainesville before being chosen for these tests, data are insufficient to determine if the added selection pressure influenced the differences between Experiments 1 and 2 .

Correlation coefficients indicate that selecting for the taller, later types in Experiment 1 would improve yields at Tancasneque slightly. In Experiment 2, correlations were weaker. Although genotypes differed in height, maturity, and other agronomic traits, they did not differ 
drastically from Jupiter in these characteristics. Initial selection of lines evidently included the proper range of plant types. 
APPENDIX 
Table 1. Mean yield of 40 soybean genotypes grown during 1979 at two locations in $\mathrm{kg} / \mathrm{ha}$, rank and as percent of overall test mean. (Test $1979, \mathrm{~A}-1$ ). Duncan's test at .05 level.

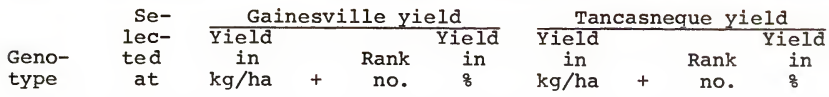

\begin{tabular}{|c|c|c|c|c|c|c|c|c|c|}
\hline Jupiter & & 1897 & $\mathrm{~F}-\mathrm{H}$ & 33 & 91 & 1683 & $\mathrm{~A}-\mathrm{H}$ & 15 & 106 \\
\hline UFV-1 & & 2145 & $A-F$ & 16 & 103 & 1998 & A & 1 & 126 \\
\hline F78-1005 & $\mathrm{T}$ & 1860 & $\mathrm{E}-\mathrm{H}$ & 37 & 89 & 1635 & $\mathrm{~A}-\mathrm{H}$ & 19 & 103 \\
\hline F 78-1015 & G & 2244 & $A-F$ & 10 & 108 & 1630 & $A-I$ & 20 & 103 \\
\hline F78-1045 & G & 2267 & $\mathrm{~A}-\mathrm{F}$ & 8 & 109 & 1525 & $B-I$ & 26 & 96 \\
\hline F78-1077 & $\mathrm{T}$ & 2329 & $A-D$ & 4 & 112 & 1717 & $A-G$ & 11 & 108 \\
\hline F78-1089 & $\mathrm{T}$ & 2167 & $A-F$ & 14 & 104 & 1837 & $A-E$ & 5 & 116 \\
\hline F78-1095 & $\mathrm{T}$ & 2185 & $A-F$ & 13 & 105 & 1607 & $A-I$ & 21 & 101 \\
\hline F78-1096 & $\mathrm{T}$ & 2051 & $\mathrm{~B}-\mathrm{F}$ & 25 & 98 & 1804 & $A-E$ & 6 & 114 \\
\hline F78-1128 & G & 2537 & A & 1 & 122 & 1727 & $A-F$ & 10 & 109 \\
\hline F78-1129 & G & 2311 & $A-E$ & 5 & 111 & 1738 & $A-F$ & 8 & 110 \\
\hline F78-1130 & G & 2068 & $B-G$ & 24 & 99 & 1883 & $A-D$ & 4 & 119 \\
\hline F78-1133 & G & 2268 & $A-F$ & 7 & 109 & 1709 & $A-G$ & 13 & 108 \\
\hline F78-1134 & G & 2420 & A-B & 2 & 116 & 1590 & $A-I$ & 22 & 100 \\
\hline F78-1141 & G & 2021 & $\mathrm{~B}-\mathrm{H}$ & 27 & 97 & 1654 & $\mathrm{~A}-\mathrm{H}$ & 17 & 104 \\
\hline F78-1160 & G & 2142 & $A-F$ & 17 & 103 & 1751 & $A-F$ & 7 & 110 \\
\hline F78-1162 & G & 2155 & $A-F$ & 15 & 103 & 1688 & $\mathrm{~A}-\mathrm{H}$ & 14 & 106 \\
\hline F78-1169 & G & 2090 & $A-G$ & 22 & 100 & 1469 & $D-I$ & 28 & 93 \\
\hline F78-1186 & $\mathrm{T}$ & 1991 & B-H & 28 & 95 & 1714 & A-G & 12 & 108 \\
\hline F78-1192 & $\mathrm{T}$ & 2258 & $A-F$ & 9 & 108 & 1933 & $A-C$ & 3 & 122 \\
\hline F78-1195 & $\mathrm{T}$ & 2047 & $B-G$ & 26 & 98 & 1647 & $\mathrm{~A}-\mathrm{H}$ & 18 & 104 \\
\hline F78-1196 & $\mathrm{T}$ & 2114 & $A-G$ & 18 & 101 & 1334 & $F-I$ & 36 & 84 \\
\hline F78-1202 & G & 2200 & $A-F$ & 12 & 105 & 1512 & C-I & 27 & 95 \\
\hline F78-1206 & $\mathrm{T}$ & 2107 & $A-G$ & 19 & 101 & 1657 & $\mathrm{~A}-\mathrm{H}$ & 16 & 104 \\
\hline F78-1411 & $\mathrm{T}$ & 2383 & $A-C$ & 3 & 114 & 1348 & $F-I$ & 34 & 85 \\
\hline F78-1424 & G & 2103 & $A-G$ & 20 & 101 & 1535 & $B-I$ & 24 & 97 \\
\hline F78-1428 & G & 1933 & $\mathrm{C}-\mathrm{H}$ & 30 & 93 & 1193 & I & 40 & 75 \\
\hline F78-1429 & G & 2091 & $A-G$ & 21 & 100 & 1411 & $E-I$ & 31 & 89 \\
\hline F 78-1430 & $\mathrm{T}$ & 1917 & $\mathrm{C}-\mathrm{H}$ & 32 & 92 & 1572 & $A-I$ & 23 & 99 \\
\hline F78-1448 & $\mathrm{T}$ & 1866 & $\mathrm{D}-\mathrm{H}$ & 36 & 89 & 1961 & $A-B$ & 2 & 124 \\
\hline F78-1457 & $\mathrm{T}$ & 1589 & $\mathrm{H}$ & 40 & 76 & 1354 & $F-I$ & 33 & 85 \\
\hline F 78-1459 & G & 2072 & $B-G$ & 23 & 99 & 1450 & $D-I$ & 29 & 91 \\
\hline F 78-1562 & $\mathrm{T}$ & 2279 & $A-E$ & 6 & 109 & 1345 & $F-I$ & 35 & 85 \\
\hline F78-1571 & $\mathrm{T}$ & 1932 & $\mathrm{C}-\overline{\mathrm{H}}$ & 31 & 93 & 1731 & $\mathrm{~A}-\mathrm{F}$ & 9 & 109 \\
\hline
\end{tabular}


Table 1-continued

\begin{tabular}{|c|c|c|c|c|c|c|c|c|c|}
\hline \multirow[b]{2}{*}{$\begin{array}{l}\text { Geno- } \\
\text { type }\end{array}$} & \multirow{2}{*}{$\begin{array}{l}\text { Se- } \\
\text { lec- } \\
\text { ted } \\
\text { at }\end{array}$} & \multicolumn{4}{|c|}{ Gainesville yield } & \multicolumn{4}{|c|}{ Tancasneque yield } \\
\hline & & $\begin{array}{c}\text { Yield } \\
\text { in } \\
\mathrm{kg} / \mathrm{ha}\end{array}$ & + & $\begin{array}{r}\text { Rank } \\
\text { no. }\end{array}$ & $\begin{array}{c}\text { Yield } \\
\text { in } \\
\%\end{array}$ & $\begin{array}{c}\text { Yield } \\
\text { in } \\
\mathrm{kg} / \mathrm{ha}\end{array}$ & + & $\begin{array}{c}\text { Rank } \\
\text { no. }\end{array}$ & $\begin{array}{c}\text { Yield } \\
\text { in } \\
\%\end{array}$ \\
\hline F78-1572 & $\mathbf{T}$ & 1673 & $\mathrm{G}-\mathrm{H}$ & 39 & 80 & 1326 & $\mathbf{F}-\mathbf{I}$ & 37 & 84 \\
\hline F78-1573 & $\mathrm{T}$ & 2216 & $A-F$ & 11 & 106 & 1355 & $\mathrm{~F}-\mathrm{I}$ & 32 & 85 \\
\hline F78-1577 & $\mathrm{T}$ & 1867 & $\mathrm{D}-\mathrm{H}$ & 35 & 90 & 1285 & G-I & 38 & 81 \\
\hline F78-1622 & G & 1804 & $\mathrm{~F}-\mathrm{H}$ & 38 & 86 & 1414 & $E-I$ & 30 & 89 \\
\hline F78-1639 & G & 1960 & $\mathrm{~B}-\mathrm{H}$ & 29 & 94 & 1532 & $\mathrm{~B}-\mathrm{I}$ & 25 & 97 \\
\hline F78-1642 & G & 1879 & $\mathrm{D}-\mathrm{H}$ & 34 & 90 & 1257 & $\mathrm{H}-\mathrm{I}$ & 39 & 79 \\
\hline Test mean & & 2086 & & & 100 & 1587 & & & 100 \\
\hline
\end{tabular}

$G$ and $T$ refer to Gainesville and Tancasneque respectively.

+ means with the same letter are not significantly different at the .05 level. 
Table 2. Agronomic characteristics of 40 soybean genotypes grown during 1979 at two locations. (Test 1979, A-1).

\begin{tabular}{|c|c|c|c|c|c|c|c|c|}
\hline \multirow[b]{2}{*}{ Genotype } & \multicolumn{2}{|c|}{ 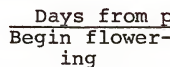 } & & \multicolumn{2}{|c|}{$\begin{array}{l}\text { Plant } \\
\text { height } \\
\text { cm }\end{array}$} & \multicolumn{2}{|c|}{$\begin{array}{l}\text { Seed } \\
\text { weight } \\
g / 100\end{array}$} \\
\hline & $\mathrm{G}$ & $\mathrm{T}$ & & $\mathrm{T}$ & $\overline{\mathrm{G}}$ & $\mathrm{T}$ & $\bar{G}$ & $T$ \\
\hline Jupiter & 49 & 48 & 114 & 102 & 93 & 84 & 15.50 & 13.0 \\
\hline UFV-1 & 43 & 42 & 108 & 100 & 72 & 51 & 11.80 & 14.0 \\
\hline F78-1005 & 49 & 49 & 115 & 100 & 81 & 65 & 18.10 & 13.0 \\
\hline F78-1015 & 47 & 46 & 118 & 102 & 90 & 77 & 17.92 & 14.0 \\
\hline F78-1045 & 43 & 42 & 114 & 102 & 95 & 59 & 18.83 & 14.0 \\
\hline F78-1077 & 42 & 42 & 111 & 98 & 86 & 68 & 18.53 & 16.0 \\
\hline F78-1089 & 46 & 43 & 114 & 102 & 83 & 84 & 13.96 & 14.0 \\
\hline F78-1095 & 45 & 43 & 117 & 104 & 92 & 54 & 19.16 & 13.0 \\
\hline F78-1096 & 42 & 42 & 113 & 103 & 87 & 52 & 19.12 & 16.0 \\
\hline F78-1128 & 47 & 43 & 118 & 104 & 92 & 61 & 20.33 & 14.0 \\
\hline F78-1129 & 40 & 42 & 106 & 100 & 88 & 54 & 16.95 & 14.0 \\
\hline F78-1130 & 42 & 43 & 114 & 104 & 82 & 72 & 21.58 & 19.0 \\
\hline F78-1133 & 41 & 43 & 113 & 103 & 87 & 95 & 18.58 & 14.0 \\
\hline F78-1134 & 45 & 46 & 118 & 103 & 84 & 64 & 18.83 & 14.0 \\
\hline F78-1141 & 53 & 50 & 116 & 104 & 95 & 69 & 13.38 & 12.0 \\
\hline F78-1160 & 49 & 46 & 114 & 100 & 98 & 91 & 14.20 & 11.0 \\
\hline F78-1162 & 45 & 43 & 116 & 103 & 91 & 60 & 16.41 & 14.0 \\
\hline F78-1169 & 45 & 42 & 108 & 100 & 107 & 89 & 16.84 & 15.0 \\
\hline F78-1186 & 42 & 42 & 108 & 100 & 93 & 62 & 15.48 & 15.0 \\
\hline F78-1192 & 45 & 42 & 114 & 102 & 87 & 74 & 17.69 & 15.0 \\
\hline F78-1195 & 45 & 42 & 116 & 102 & 94 & 83 & 16.06 & 15.0 \\
\hline F78-1196 & 44 & 43 & 112 & 98 & 85 & 58 & 19.22 & 15.0 \\
\hline F78-1202 & 49 & 48 & 114 & 100 & 97 & 72 & 15.34 & 11.0 \\
\hline F78-1206 & 49 & 50 & 113 & 102 & 97 & 104 & 14.81 & 11.0 \\
\hline F78-1411 & 50 & 49 & 124 & 108 & 117 & 78 & 13.52 & 11.0 \\
\hline F78-1424 & 45 & 42 & 118 & 102 & 106 & 80 & 11.81 & 12.0 \\
\hline F78-1428 & 53 & 52 & 114 & 109 & 103 & 99 & 14.01 & 11.0 \\
\hline F78-1429 & 49 & 49 & 114 & 106 & 98 & 87 & 15.80 & 14.0 \\
\hline F78-1430 & 45 & 44 & 123 & 109 & 98 & 72 & 14.42 & 12.0 \\
\hline F78-1448 & 38 & 38 & 100 & 100 & 64 & 71 & 16.66 & 16.0 \\
\hline F78-1457 & 33 & 35 & 92 & 93 & 49 & 68 & 14.59 & 15.0 \\
\hline F78-1459 & 37 & 42 & 98 & 93 & 69 & 62 & 16.58 & 16.0 \\
\hline F78-1562 & 38 & 36 & 106 & 93 & 67 & 53 & 16.22 & 18.0 \\
\hline F78-1571 & 38 & 36 & 108 & 98 & 63 & 59 & 14.59 & 16.0 \\
\hline
\end{tabular}


Table 2-continued

\begin{tabular}{|c|c|c|c|c|c|c|c|c|}
\hline \multirow[b]{2}{*}{ Genotype } & $\begin{array}{c}\text { Days } \\
\text { Begin } \\
\text { ir }\end{array}$ & $\begin{array}{l}\text { from p } \\
\text { flower- }\end{array}$ & $\frac{\text { lanting }}{\text { Matu }}$ & to: & \multicolumn{2}{|c|}{$\begin{array}{l}\text { Plant } \\
\text { height } \\
\text { cm }\end{array}$} & \multicolumn{2}{|c|}{$\begin{array}{c}\text { Seed } \\
\text { weight } \\
\mathrm{g} / 100 \\
\end{array}$} \\
\hline & G & $\mathrm{T}$ & $\bar{G}$ & $T$ & $\overline{\mathrm{G}}$ & $T$ & $\overline{\mathrm{G}}$ & $T$ \\
\hline $\begin{array}{l}\text { F78-1572 } \\
\text { F78-1573 } \\
\text { F78-1577 } \\
\text { F78-1622 } \\
\text { F78-1639 } \\
\text { F78-1642 }\end{array}$ & $\begin{array}{l}38 \\
40 \\
38 \\
37 \\
37 \\
38\end{array}$ & $\begin{array}{l}36 \\
38 \\
36 \\
36 \\
36 \\
35\end{array}$ & $\begin{array}{l}103 \\
108 \\
108 \\
103 \\
105 \\
103\end{array}$ & $\begin{array}{l}93 \\
94 \\
92 \\
92 \\
90 \\
92\end{array}$ & $\begin{array}{l}75 \\
78 \\
73 \\
69 \\
67 \\
81\end{array}$ & $\begin{array}{l}57 \\
54 \\
60 \\
53 \\
68 \\
40\end{array}$ & $\begin{array}{l}13.28 \\
15.39 \\
15.04 \\
16.32 \\
14.86 \\
14.76\end{array}$ & $\begin{array}{l}16.0 \\
16.0 \\
17.0 \\
19.0 \\
16.0 \\
16.0\end{array}$ \\
\hline Mean & 43.52 & 42.55 & 111.27 & 100.05 & 85.82 & 69.07 & 16.16 & 14.42 \\
\hline
\end{tabular}

G and $T$ refer to Gainesville and Tancasneque respectively. 
Table 3. Mean yield of 24 soybean genotypes grown during 1980 at four locations in $\mathrm{kg} / \mathrm{ha}$, rank, and as percent of overall test mean. (Test 1980, A-3). Duncan's test at .05 level.

\begin{tabular}{|c|c|c|c|c|c|c|c|c|}
\hline \multirow[b]{2}{*}{ Genotype } & \multicolumn{4}{|c|}{ Gainesville yield } & \multicolumn{4}{|c|}{ Tancasneque yield } \\
\hline & $\begin{array}{l}\text { Yield } \\
\text { in } \\
\mathrm{kg} / \mathrm{ha}\end{array}$ & + & $\begin{array}{r}\text { Rank } \\
\text { no. }\end{array}$ & $\begin{array}{c}\text { Yield } \\
\text { in } \\
\frac{8}{8}\end{array}$ & $\begin{array}{c}\text { Yield } \\
\text { in } \\
\mathrm{kg} / \mathrm{ha}\end{array}$ & + & $\begin{array}{r}\text { Rank } \\
\text { no. }\end{array}$ & $\begin{array}{c}\text { Yield } \\
\text { in } \\
8\end{array}$ \\
\hline Jupiter & 1681 & $\mathrm{~A}-\mathrm{C}$ & 13 & 100 & 1551 & $D-E$ & 15 & 97 \\
\hline UFV-1 & 1742 & $A-B$ & 10 & 103 & 1631 & $B-E$ & 9 & 102 \\
\hline F75-9207 & 1834 & A & 3 & 109 & 1664 & $B-D$ & 5 & 104 \\
\hline F78-1045 & 1614 & $A-C$ & 19 & 96 & 1616 & $\mathrm{~B}-\mathrm{E}$ & 10 & 101 \\
\hline F78-1077 & 1594 & $A-D$ & 20 & 94 & 1542 & $\mathrm{D}-\mathrm{E}$ & 16 & 97 \\
\hline F78-1089 & 1657 & $A-C$ & 17 & 98 & 1673 & $B-D$ & 4 & 105 \\
\hline F78-1128 & 1743 & $A-B$ & 9 & 103 & 1928 & $A-B$ & 2 & 121 \\
\hline F78-1129 & 1725 & $A-B$ & 12 & 102 & 1574 & $\mathrm{C}-\mathrm{E}$ & 13 & 99 \\
\hline F78-1130 & 1870 & A & 1 & 111 & 1662 & B-D & 6 & 104 \\
\hline F78-1133 & 1819 & A & 5 & 108 & 1563 & $C-E$ & 14 & 98 \\
\hline F78-1134 & 1817 & A & 6 & 108 & 2156 & A & 1 & 135 \\
\hline F78-1160 & 1650 & $A-C$ & 18 & 98 & 1360 & $D-E$ & 23 & 85 \\
\hline F78-1162 & 1834 & A & 4 & 109 & 1662 & $B-D$ & 7 & 104 \\
\hline F78-1169 & 1839 & A & 2 & 109 & 1527 & $D-E$ & 17 & 96 \\
\hline F78-1192 & 1680 & $A-C$ & 14 & 100 & 1612 & $B-E$ & il & 101 \\
\hline F78-1195 & 1788 & $A-B$ & 8 & 106 & 1606 & $B-E$ & 12 & 101 \\
\hline F78-1206 & 1728 & $A-B$ & 11 & 102 & 1637 & $B-E$ & 8 & 103 \\
\hline F78-1411 & 1658 & $A-C$ & 16 & 98 & 1906 & $A-C$ & 3 & 120 \\
\hline F78-1428 & 1579 & $A-D$ & 21 & 94 & 1417 & D-E & 20 & 89 \\
\hline F $78-1448$ & 1658 & $A-C$ & 15 & 98 & 1376 & $\mathrm{D}-\mathrm{E}$ & 22 & 86 \\
\hline F78-1457 & 1298 & D & 24 & 77 & 1401 & $\mathrm{D}-\mathrm{E}$ & 21 & 88 \\
\hline F78-1562 & 1477 & $B-D$ & 22 & 88 & 1423 & $\mathrm{D}-\mathrm{E}$ & 19 & 89 \\
\hline F78-1571 & 1802 & $A-B$ & 7 & 107 & 1478 & $D-E$ & 18 & 93 \\
\hline \multirow[t]{2}{*}{ F78-1639 } & 1383 & $C-D$ & 23 & 82 & 1287 & E & 24 & 81 \\
\hline & 1686 & & & 100 & 1594 & & & 100 \\
\hline
\end{tabular}

+ means with the same letter are not significantly different at the .05 level. 
Table 3-extended

\begin{tabular}{|c|c|c|c|c|c|c|c|}
\hline \multicolumn{4}{|c|}{ Tapachula yield } & \multicolumn{4}{|c|}{ Boliche yield } \\
\hline Yield & & & Yield & Yield & & & Yield \\
\hline 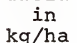 & + & Rank & in & in & + & Rank & in \\
\hline 3341 & A & 5 & 110 & 742 & $E-F$ & 23 & 56 \\
\hline 3251 & A & 7 & 107 & 1377 & $A-D$ & 9 & 104 \\
\hline 2743 & A & 20 & 90 & 1324 & $A-D$ & 13 & 100 \\
\hline 3604 & A & 2 & 118 & 1427 & $A-D$ & 7 & 108 \\
\hline 2884 & A & 17 & 95 & 1134 & $\mathrm{D}-\mathrm{F}$ & 21 & 86 \\
\hline 3202 & A & 11 & 105 & 1140 & $\mathrm{D}-\mathrm{F}$ & 20 & 86 \\
\hline 3695 & A & 1 & 121 & 1366 & $A-D$ & 10 & 103 \\
\hline 2784 & A & 19 & 91 & 1296 & $A-D$ & 15 & 98 \\
\hline 3456 & A & 3 & 113 & 1852 & A & 1 & 140 \\
\hline 3120 & A & 12 & 102 & 1199 & $D-E$ & 18 & 91 \\
\hline 3406 & A & 4 & 112 & 1542 & $A-D$ & 5 & 116 \\
\hline 3119 & A & 13 & 102 & 1381 & $A-D$ & 8 & 104 \\
\hline 3234 & A & 9 & 106 & 1546 & $A-D$ & 4 & 117 \\
\hline 3246 & A & 8 & 107 & 1520 & $A-D$ & 6 & 115 \\
\hline 3041 & A & 15 & 100 & 1269 & $B-E$ & 16 & 96 \\
\hline 3271 & A & 6 & 107 & 1803 & $A-B$ & 2 & 136 \\
\hline 3034 & A & 16 & 100 & 1300 & $A-D$ & 14 & 98 \\
\hline 2102 & A & 24 & 69 & 1784 & $A-C$ & 3 & 135 \\
\hline 2627 & A & 21 & 86 & 1230 & $\mathrm{C}-\mathrm{E}$ & 17 & 93 \\
\hline 2851 & A & 18 & 94 & 1361 & $A-D$ & 11 & 103 \\
\hline 2199 & A & 23 & 72 & 659 & $\mathrm{~F}$ & 24 & 50 \\
\hline 3114 & A & 14 & 102 & 1353 & $A-D$ & 12 & 102 \\
\hline 2558 & A & 22 & 84 & 1150 & $D-F$ & 19 & 87 \\
\hline 3230 & A & 10 & 106 & 1017 & $D-F$ & 22 & 77 \\
\hline 3046 & & & 100 & 1324 & & & 100 \\
\hline
\end{tabular}


Table 4. Agronomic characteristics of 24 soybean genotypes grown during 1980 at four locations. (Test 1980, $\mathrm{A}-3$ ).

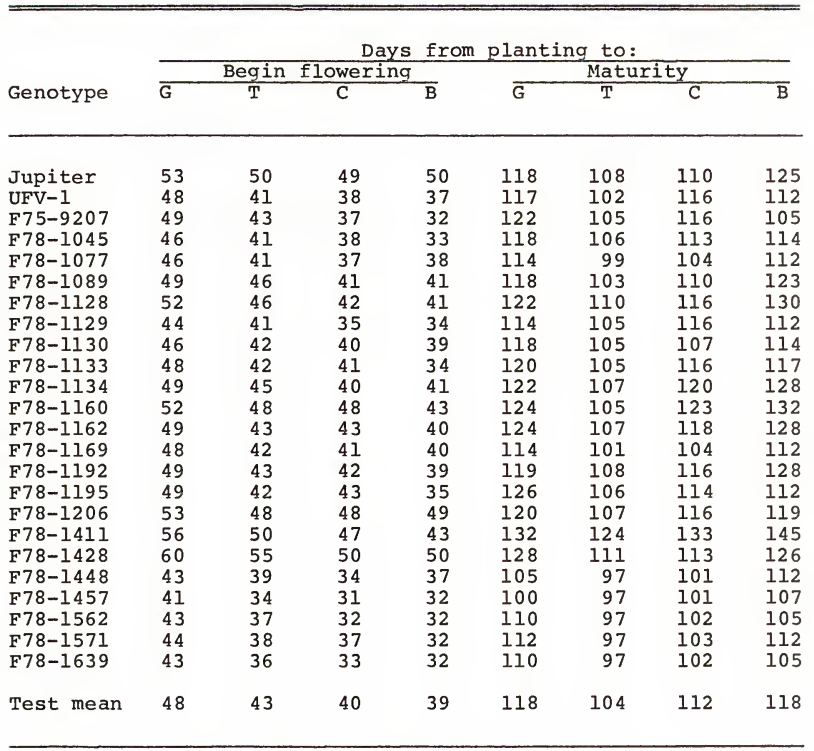

G, T, C and B refer to Gainesville, Tancasneque, Tapachula and Boliche respectively. 
Table 4-extended

\begin{tabular}{|c|c|c|c|c|c|c|c|c|c|}
\hline \multicolumn{4}{|c|}{$\begin{array}{c}\text { Plant height } \\
\mathrm{cm}\end{array}$} & \multicolumn{3}{|c|}{$\begin{array}{c}\text { Seed weight } \\
\mathrm{g} / 100\end{array}$} & \multicolumn{2}{|c|}{$\begin{array}{c}\text { Node } \\
\text { number }\end{array}$} & \multirow{2}{*}{$\begin{array}{c}\begin{array}{c}\text { Canopy } \\
\text { width }(\mathrm{cm})\end{array} \\
\mathrm{G}\end{array}$} \\
\hline$\overline{\mathrm{G}}$ & $T$ & $\mathrm{C}$ & $\bar{B}$ & $\overline{\mathrm{G}}$ & $\mathrm{T}$ & $\bar{B}$ & $\overline{\mathrm{G}}$ & $T$ & \\
\hline 76 & 64 & 83 & 54 & 13.23 & 14 & 24.2 & 12 & 11 & 45 \\
\hline 47 & 35 & 66 & 32 & 10.56 & 13 & 20.5 & 11 & 8 & 50 \\
\hline 67 & 56 & 77 & 25 & 12.88 & 12 & 19.2 & 17 & 13 & 60 \\
\hline 80 & 68 & 91 & 45 & 15.80 & 14 & 23.8 & 12 & 10 & 50 \\
\hline 55 & 46 & 79 & 39 & 14.82 & 15 & 18.8 & 11 & 10 & 55 \\
\hline 60 & 55 & 78 & 49 & 11.14 & 13 & 18.6 & 11 & 10 & 55 \\
\hline 70 & 72 & 89 & 51 & 16.93 & 15 & 25.4 & 12 & 11 & 55 \\
\hline 77 & 65 & 80 & 37 & 15.23 & 13 & 21.7 & 11 & 10 & 50 \\
\hline 62 & 58 & 89 & 50 & 15.22 & 16 & 23.1 & 11 & 11 & 55 \\
\hline 85 & 76 & 92 & 59 & 16.46 & 15 & 22.7 & 13 & 11 & 50 \\
\hline 80 & 67 & 97 & 48 & 16.99 & 16 & 23.7 & 13 & 12 & 60 \\
\hline 85 & 72 & 98 & 59 & 13.71 & 13 & 21.4 & 15 & 12 & 55 \\
\hline 70 & 60 & 87 & 47 & 14.61 & 15 & 22.4 & 12 & 10 & 55 \\
\hline 60 & 64 & 98 & 70 & 15.66 & 15 & 21.5 & 12 & 11 & 55 \\
\hline 75 & 71 & 90 & 51 & 14.82 & 15 & 24.7 & 13 & 10 & 50 \\
\hline 80 & 68 & 86 & 42 & 15.34 & 14 & 22.2 & 13 & 11 & 55 \\
\hline 77 & 70 & 87 & 61 & 13.57 & 14 & 22.8 & 13 & 11 & 55 \\
\hline 112 & 114 & 131 & 82 & 13.14 & 15 & 20.1 & 21 & 18 & 70 \\
\hline 82 & 68 & 94 & 62 & 13.15 & 15 & 20.3 & 17 & 13 & 65 \\
\hline 60 & 44 & 66 & 40 & 13.54 & 17 & 20.4 & 12 & 12 & 50 \\
\hline 42 & 34 & 57 & 28 & 14.01 & 15 & 19.4 & 12 & 10 & 45 \\
\hline 55 & 56 & 69 & 30 & 13.71 & 15 & 23.8 & 12 & 11 & 50 \\
\hline 57 & 44 & 64 & 26 & 11.67 & 13 & 23.5 & 11 & 10 & 55 \\
\hline 50 & 50 & 68 & 26 & 13.13 & 13 & 20.6 & 13 & 11 & 45 \\
\hline 69 & 61 & 84 & 46 & 14.14 & 14 & 21.9 & 13 & 11 & 54 \\
\hline
\end{tabular}


Table 5. Mean yield of 40 soybean genotypes grown during 1979 at two locations in $\mathrm{kg} / \mathrm{ha}$, rank and as percent of overall test mean. (Test 1979, A-2). Duncan's test at .05 level.

\begin{tabular}{|c|c|c|c|c|c|c|c|c|c|}
\hline \multirow[b]{2}{*}{$\begin{array}{l}\text { Geno- } \\
\text { type }\end{array}$} & \multirow{2}{*}{$\begin{array}{l}\text { Se- } \\
\text { lec- } \\
\text { ted } \\
\text { at }\end{array}$} & \multicolumn{4}{|c|}{ Gainesville yield } & \multicolumn{4}{|c|}{ Tancasneque yield } \\
\hline & & $\begin{array}{c}\text { Yield } \\
\text { in } \\
\mathrm{kg} / \mathrm{ha}\end{array}$ & + & $\begin{array}{r}\text { Rank } \\
\text { no. }\end{array}$ & $\begin{array}{c}\text { Yield } \\
\text { in } \\
q\end{array}$ & $\begin{array}{c}\text { Yield } \\
\text { in } \\
\mathrm{kg} / \mathrm{ha}\end{array}$ & + & $\begin{array}{c}\text { Rank } \\
\text { no. }\end{array}$ & $\begin{array}{c}\text { Yield } \\
\text { in } \\
\frac{8}{8}\end{array}$ \\
\hline Jupiter & & 1883 & $\mathrm{C}-\mathrm{N}$ & 22 & 97 & 1579 & $B-G$ & 23 & 96 \\
\hline UFV-1 & & 2057 & $\mathrm{C}-\mathrm{L}$ & 15 & 106 & 1699 & $A-G$ & 16 & 103 \\
\hline F78-1219 & $\mathrm{T}$ & 1818 & $\mathrm{D}-\mathrm{N}$ & 27 & 94 & 1874 & $\mathrm{~A}-\mathrm{F}$ & 8 & 113 \\
\hline F $78-1220$ & $\mathrm{~T}$ & 1968 & $\mathrm{C}-\mathrm{M}$ & 18 & 101 & 1625 & $B-G$ & 19 & 98 \\
\hline F 78-1221 & G & 1756 & $\mathrm{~F}-\mathrm{N}$ & 31 & 90 & 2122 & $\mathrm{~A}-\mathrm{C}$ & 4 & 128 \\
\hline F 78-1236 & G & 1560 & $\mathrm{~K}-\mathrm{N}$ & 37 & 80 & 1833 & $\mathrm{~A}-\mathrm{G}$ & 12 & 111 \\
\hline F78-1237 & G & 1597 & $\mathrm{I}-\mathrm{N}$ & 35 & 82 & 1363 & $D-G$ & 36 & 83 \\
\hline F78-1240 & G & 1788 & $\mathrm{E}-\mathrm{N}$ & 29 & 92 & 1855 & $A-G$ & 10 & 112 \\
\hline F 78-1241 & G & 2305 & $A-E$ & 5 & 119 & 1495 & $C-G$ & 27 & 90 \\
\hline F78-1243 & G & 1913 & $\mathrm{C}-\mathrm{N}$ & 21 & 98 & 1725 & $A-G$ & 14 & 104 \\
\hline F78-1244 & G & 1644 & $\mathrm{H}-\mathrm{N}$ & 34 & 85 & 1561 & $B-G$ & 25 & 94 \\
\hline F 78-1246 & G & 2121 & B-H & 10 & 109 & 1162 & G & 40 & 70 \\
\hline F78-1247 & G & 2120 & $B-I$ & 11 & 109 & 1443 & $\mathrm{C}-\mathrm{G}$ & 32 & 87 \\
\hline F78-1250 & $\mathrm{T}$ & 2651 & A & 1 & 136 & 1854 & $A-G$ & 11 & 112 \\
\hline F 78-1251 & $\mathrm{T}$ & 1954 & $\mathrm{C}-\mathrm{M}$ & 19 & 101 & 1997 & $A-D$ & 5 & 121 \\
\hline F 78-1278 & $\mathbf{G}$ & 1417 & $\mathrm{~N}$ & 40 & 73 & 1407 & $\mathrm{D}-\mathrm{G}$ & 34 & 85 \\
\hline F 78-1294 & $\mathrm{T}$ & 1452 & $M-N$ & 39 & 75 & 1520 & $\mathrm{C}-\mathrm{G}$ & 26 & 92 \\
\hline F78-1310 & $\mathrm{T}$ & 1702 & $\mathrm{G}-\mathrm{N}$ & 32 & 88 & 1451 & $\mathrm{C}-\mathrm{G}$ & 31 & 88 \\
\hline F78-1314 & $\mathrm{T}$ & 1812 & $\mathrm{D}-\mathrm{N}$ & 28 & 93 & 1488 & $\mathrm{C}-\mathrm{G}$ & 28 & 90 \\
\hline F78-1316 & G & 2133 & B-H & 9 & 110 & 1625 & B-G & 18 & 98 \\
\hline F78-1319 & G & 1843 & $\mathrm{D}-\mathrm{N}$ & 24 & 95 & 1226 & E-G & 38 & 74 \\
\hline F78-1331 & $\mathrm{T}$ & 2335 & $A-D$ & 4 & 120 & 2230 & $A-B$ & 2 & 135 \\
\hline F78-1347 & $\mathrm{T}$ & 1883 & $\mathrm{C}-\mathrm{N}$ & 23 & 97 & 1873 & $A-F$ & 9 & 113 \\
\hline F78-1350 & $\mathrm{T}$ & 2073 & $B-K$ & 14 & 107 & 1893 & $A-E$ & 7 & 115 \\
\hline F78-1351 & G & 2367 & $A-C$ & 3 & 122 & 1953 & $A-D$ & 6 & 118 \\
\hline F 78-1373 & G & 2177 & $A-G$ & 7 & 112 & 1743 & $A-G$ & 13 & 106 \\
\hline F 78-1377 & G & 2580 & $A-B$ & 2 & 133 & 2365 & A & 1 & 143 \\
\hline F 78-1378 & $\mathrm{T}$ & 2262 & $A-F$ & 6 & 116 & 1617 & $\mathrm{~B}-\mathrm{G}$ & 20 & 98 \\
\hline F78-1398 & $\mathrm{T}$ & 2103 & $\mathrm{~B}-\mathrm{J}$ & 12 & 108 & 1584 & B-G & 22 & 96 \\
\hline F 78-1402 & $\mathbf{G}$ & 2012 & C-L & 17 & 104 & 1456 & $\mathrm{C}-\mathrm{G}$ & 30 & 88 \\
\hline F78-1464 & $\mathrm{T}$ & 1839 & $\mathrm{D}-\mathrm{N}$ & 25 & 95 & 1572 & B-G & 24 & 95 \\
\hline F78-1469 & $\mathrm{T}$ & 2027 & $C-I$ & 16 & 104 & 1714 & $A-G$ & 15 & 104 \\
\hline F78-1490 & $\mathrm{T}$ & 1662 & $\mathrm{G}-\mathrm{N}$ & 33 & 86 & 1191 & $F-G$ & 39 & 72 \\
\hline F78-1496 & $\mathrm{T}$ & 1763 & $\mathrm{~F}-\mathrm{N}$ & 30 & 91 & 1401 & $D-G$ & 35 & 85 \\
\hline
\end{tabular}


Table 5-continued

\begin{tabular}{|c|c|c|c|c|c|c|c|c|c|}
\hline \multirow[b]{2}{*}{$\begin{array}{l}\text { Geno- } \\
\text { type }\end{array}$} & \multirow{2}{*}{$\begin{array}{l}\text { Se- } \\
\text { lec- } \\
\text { ted } \\
\text { at }\end{array}$} & \multicolumn{4}{|c|}{ Gainesville yield } & \multicolumn{4}{|c|}{ Tancasneque yield } \\
\hline & & $\begin{array}{c}\text { Yield } \\
\text { in } \\
\mathrm{kg} / \mathrm{ha}\end{array}$ & + & $\begin{array}{r}\text { Rank } \\
\text { no. }\end{array}$ & $\begin{array}{c}\text { Yield } \\
\text { in } \\
\text { \% }\end{array}$ & $\begin{array}{c}\text { Yield } \\
\text { in } \\
\mathrm{kg} / \mathrm{ha}\end{array}$ & + & $\begin{array}{r}\text { Rank } \\
\text { no. }\end{array}$ & $\begin{array}{c}\text { Yield } \\
\text { in } \\
8\end{array}$ \\
\hline F 78-1500 & G & 1583 & $\mathrm{~J}-\mathrm{N}$ & 36 & 81 & 1604 & $B-G$ & 21 & 97 \\
\hline F78-1503 & G & 2102 & $\mathrm{~B}-\mathrm{J}$ & 13 & 108 & 1477 & $\mathrm{C}-\mathrm{G}$ & 29 & 89 \\
\hline F78-1520 & G & 1835 & $\mathrm{D}-\mathrm{N}$ & 26 & 94 & 1323 & $D-G$ & 37 & 80 \\
\hline F 78-1536 & $\mathrm{T}$ & 1916 & $\mathrm{C}-\mathrm{M}$ & 20 & 99 & 1640 & $\mathrm{~B}-\mathrm{G}$ & 17 & 99 \\
\hline F78-1541 & $\mathbf{T}$ & 2167 & $\mathrm{~A}-\mathrm{H}$ & 8 & 112 & 2127 & $A-C$ & 3 & 129 \\
\hline F78-1558 & $\mathrm{T}$ & 1547 & $\mathrm{~L}-\mathrm{N}$ & 38 & 80 & 1441 & $C-G$ & 33 & 87 \\
\hline Test mean & & 1943 & & & 100 & 1652 & & & 100 \\
\hline
\end{tabular}

$G$ and $T$ refer to Gainesville and Tancasneque respectively.

+ means with the same letter are not significantly different at the .05 level. 
Table 6. Agronomic characteristics of 40 soybean genotypes grown during 1979 at two locations. (Test 1979, $\mathrm{A}-2$ ) .

\begin{tabular}{|c|c|c|c|c|c|c|c|c|}
\hline \multirow[b]{2}{*}{ Genotype } & \multirow{2}{*}{\multicolumn{2}{|c|}{$\begin{array}{l}\frac{\text { Days from p }}{\text { Begin flower- }} \\
\text { ing } \\
\text { G }\end{array}$}} & \multirow{2}{*}{\multicolumn{2}{|c|}{$\frac{\text { to: }}{\frac{\text { arity }}{T}}$}} & \multicolumn{2}{|c|}{$\begin{array}{l}\text { Plant } \\
\text { height } \\
\text { cm }\end{array}$} & \multicolumn{2}{|c|}{$\begin{array}{c}\text { Seed } \\
\text { weight } \\
\text { g/100 } \\
\end{array}$} \\
\hline & & & & & $\overline{\mathrm{G}}$ & T & & $T$ \\
\hline Jupiter & 49 & 49 & 114 & 101 & 86 & 67 & 15.89 & 14.0 \\
\hline UFV-1 & 43 & 42 & 108 & 102 & 66 & 47 & 11.82 & 14.0 \\
\hline F78-1219 & 40 & 39 & 106 & 100 & 70 & 54 & 11.63 & 14.0 \\
\hline F 78-1220 & 47 & 47 & 111 & 99 & 87 & 54 & 17.30 & 15.0 \\
\hline F78-1221 & 44 & 41 & 114 & 98 & 95 & 95 & 16.58 & 15.0 \\
\hline F 78-1236 & 47 & 48 & 114 & 107 & 84 & 71 & 15.22 & 14.0 \\
\hline F 78-1237 & 46 & 43 & 106 & 98 & 76 & 62 & 15.33 & 14.0 \\
\hline F 78-1240 & 48 & 48 & 112 & 102 & 88 & 87 & 15.12 & 14.0 \\
\hline F78-1241 & 42 & 38 & 108 & 100 & 90 & 57 & 15.66 & 15.0 \\
\hline F78-1243 & 46 & 45 & 108 & 96 & 83 & 77 & 14.92 & 14.0 \\
\hline F 78-1244 & 43 & 42 & 106 & 100 & 66 & 61 & 16.97 & 16.0 \\
\hline F78-1246 & 47 & 46 & 106 & 99 & 87 & 44 & 15.02 & 14.0 \\
\hline F78-1247 & 47 & 46 & 108 & 100 & 90 & 70 & 17.49 & 14.0 \\
\hline F 78-1250 & 44 & 45 & 114 & 104 & 112 & 101 & 16.79 & 14.0 \\
\hline F 78-1251 & 49 & 50 & 115 & 100 & 90 & 83 & 16.24 & 15.0 \\
\hline F 78-1278 & 49 & 49 & 112 & 98 & 99 & 60 & 14.16 & 13.0 \\
\hline F78-1294 & 45 & 46 & 108 & 96 & 63 & 61 & 9.23 & 10.0 \\
\hline F 78-1310 & 45 & 42 & 113 & 96 & 60 & 46 & 8.82 & 8.0 \\
\hline F78-1314 & 44 & 42 & 111 & 96 & 59 & 44 & 9.14 & 9.0 \\
\hline F78-1316 & 43 & 46 & 114 & 101 & 70 & 70 & 10.33 & 9.0 \\
\hline F78-1319 & 44 & 44 & 106 & 99 & 60 & 51 & 8.45 & 9.0 \\
\hline F78-1331 & 45 & 43 & 113 & 100 & 109 & 96 & 15.46 & 15.0 \\
\hline F78-1347 & 45 & 42 & 114 & 102 & 107 & 81 & 13.62 & 14.0 \\
\hline F78-1350 & 43 & 44 & 113 & 101 & 82 & 71 & 13.01 & 13.0 \\
\hline F78-1351 & 49 & 48 & 124 & 112 & 87 & 74 & 13.62 & 14.0 \\
\hline F 78-1373 & 47 & 45 & 124 & 103 & 92 & 60 & 13.21 & 12.0 \\
\hline F 78-1377 & 43 & 42 & 114 & 102 & 87 & 79 & 14.59 & 14.0 \\
\hline F 78-1378 & 45 & 46 & 124 & 111 & 91 & 58 & 13.51 & 12.0 \\
\hline F78-1398 & 50 & 49 & 124 & 113 & 85 & 62 & 11.53 & 12.0 \\
\hline F 78-1402 & 51 & 44 & 124 & 111 & 82 & 65 & 12.43 & 12.0 \\
\hline F78-1464 & 42 & 42 & 108 & 98 & 77 & 62 & 12.75 & 12.0 \\
\hline F78-1469 & 43 & 45 & 114 & 112 & 87 & 81 & 14.93 & 14.0 \\
\hline F78-1490 & 48 & 52 & 111 & 111 & 89 & 76 & 16.68 & 16.0 \\
\hline F 78-1496 & 38 & 41 & 103 & 96 & 70 & 46 & 14.22 & 15.0 \\
\hline
\end{tabular}


Table 6-continued

\begin{tabular}{|c|c|c|c|c|c|c|c|c|}
\hline \multirow{2}{*}{ Genotype } & \multicolumn{4}{|c|}{$\frac{\text { Days from planting to: }}{\text { Begin flower- }}$} & \multicolumn{2}{|c|}{$\begin{array}{l}\text { Plant } \\
\text { height } \\
\mathrm{cm}\end{array}$} & \multirow{2}{*}{\multicolumn{2}{|c|}{$\begin{array}{c}\text { Seed } \\
\text { weight } \\
g / 100 \\
\end{array}$}} \\
\hline & $\mathrm{G}$ & $\mathrm{T}$ & $\overline{\mathrm{G}}$ & $\mathrm{T}$ & $\bar{G}$ & $T$ & & $\mathrm{~T}$ \\
\hline $\begin{array}{l}\text { F78-1500 } \\
\text { F78-1503 } \\
\text { F78-1520 } \\
\text { F78-1536 } \\
\text { F78-1541 } \\
\text { F78-1558 }\end{array}$ & $\begin{array}{l}43 \\
38 \\
38 \\
47 \\
39 \\
37\end{array}$ & $\begin{array}{l}42 \\
37 \\
37 \\
45 \\
42 \\
36\end{array}$ & $\begin{array}{l}114 \\
108 \\
103 \\
114 \\
112 \\
103\end{array}$ & $\begin{array}{r}100 \\
100 \\
92 \\
106 \\
102 \\
101\end{array}$ & $\begin{array}{r}100 \\
72 \\
67 \\
115 \\
83 \\
49\end{array}$ & $\begin{array}{l}76 \\
51 \\
61 \\
83 \\
78 \\
45\end{array}$ & $\begin{array}{l}16.99 \\
14.15 \\
13.96 \\
14.97 \\
16.30 \\
15.91\end{array}$ & $\begin{array}{l}14.0 \\
14.0 \\
14.0 \\
14.0 \\
16.0 \\
17.0\end{array}$ \\
\hline Mean & 44.57 & 44.00 & 111.95 & 101.62 & 82.80 & 66.67 & 14.09 & 13.45 \\
\hline
\end{tabular}

$\mathrm{G}$ and $\mathrm{T}$ refer to Gainesville and Tancasneque respectively. 
Table 7. Mean yield of 24 soybean genotypes grown during 1980 at four locations in $\mathrm{kg} / \mathrm{ha}$, rank and as percent of overall test mean. (Test 1980, A-4). Duncan's test at .05 level.

\begin{tabular}{|c|c|c|c|c|c|c|c|c|}
\hline \multirow[b]{2}{*}{ Genotype } & \multicolumn{4}{|c|}{ Gainesville yield } & \multicolumn{4}{|c|}{ Tancasneque yield } \\
\hline & $\begin{array}{c}\text { Yield } \\
\text { in } \\
\mathrm{kg} / \mathrm{ha}\end{array}$ & + & $\begin{array}{c}\text { Rank } \\
\text { no. }\end{array}$ & $\begin{array}{c}\text { Yield } \\
\text { in } \\
8\end{array}$ & $\begin{array}{c}\text { Yield } \\
\text { in } \\
\mathrm{kg} / \mathrm{ha}\end{array}$ & + & $\begin{array}{r}\text { Rank } \\
\text { no. }\end{array}$ & $\begin{array}{c}\text { Yielo } \\
\text { in } \\
8\end{array}$ \\
\hline Jupiter & 1685 & A & 21 & 91 & 1839 & $B-E$ & 10 & 106 \\
\hline UFV-1 & 2061 & A & 3 & 112 & 1805 & $B-E$ & 11 & 104 \\
\hline F75-9207 & 2051 & A & 4 & 111 & 1883 & $A-D$ & 5 & 108 \\
\hline F78-1219 & 1815 & A & 13 & 98 & 1645 & $\mathrm{C}-\mathrm{F}$ & 16 & 94 \\
\hline F 78- 1220 & 1921 & A & 7 & 104 & 2135 & $A-B$ & 2 & 123 \\
\hline F78-1221 & 1657 & A & 22 & 90 & 1676 & B-F & 15 & 96 \\
\hline F78-1236 & 1699 & A & 20 & 92 & 1870 & $A-E$ & 7 & 107 \\
\hline F $78-1240$ & 1711 & A & 19 & 93 & 1786 & $B-E$ & 12 & 103 \\
\hline F78-1241 & 1625 & A & 24 & 88 & 1763 & $\mathrm{~B}-\mathrm{E}$ & 13 & 101 \\
\hline F78-1243 & 1753 & $\mathrm{~A}$ & 16 & 95 & 1570 & $\mathrm{C}-\mathrm{F}$ & 19 & 90 \\
\hline F78-1246 & 1853 & A & 11 & 100 & 1465 & $D-F$ & 22 & 84 \\
\hline F78-1247 & 1803 & A & 14 & 98 & 1268 & $\mathrm{~F}$ & 24 & 73 \\
\hline F78-1250 & 1995 & A & 5 & 108 & 1881 & $A-D$ & 6 & 108 \\
\hline F78-1251 & 1993 & A & 6 & 108 & 1866 & $A-E$ & 8 & 107 \\
\hline F78-1316 & 1743 & A & 17 & 95 & 1475 & D-F & 21 & 85 \\
\hline F78-1331 & 2061 & A & 2 & 112 & 1887 & $A-D$ & 4 & 108 \\
\hline F78-1347 & 1713 & A & 18 & 93 & 1477 & $\mathrm{D}-\mathrm{F}$ & 20 & 85 \\
\hline F78-1350 & 1913 & A & 9 & 104 & 1389 & $E-F$ & 23 & 80 \\
\hline F78-1351 & 1788 & A & 15 & 97 & 1604 & $\mathrm{C}-\mathrm{F}$ & 17 & 92 \\
\hline F78-1373 & 2125 & A & 1 & 115 & 1861 & $A-E$ & 9 & 107 \\
\hline F78-1377 & 1893 & A & 10 & 103 & 2321 & A & 1 & 133 \\
\hline F78-1378 & 1837 & A & 12 & 100 & 1967 & $\mathrm{~A}-\mathrm{C}$ & 3 & 113 \\
\hline F78-1469 & 1634 & A & 23 & 89 & 1727 & B-F & 14 & 99 \\
\hline F78-1541 & 1915 & A & 8 & 104 & 1600 & $C-F$ & 18 & 92 \\
\hline & 1844 & & & & 1740 & & & \\
\hline
\end{tabular}

+ means with the same letter are not significantly different at the .05 level. 
Table 7-extended

Yield
in

$\mathrm{kg} / \mathrm{ha}+$ no.
Tapachula yield Yield in in

\begin{tabular}{ccc}
\multicolumn{3}{c}{ Boliche yield } \\
Yield & Yield \\
in & Rank & in \\
$\mathrm{kg} / \mathrm{ha}+$ no. & 8
\end{tabular}$$
\text { (2) }
$$

$\begin{array}{rlrrl}3320 & \text { A-D } & 6 & 106 & 1224 \\ 3535 & \mathrm{~A}-\mathrm{B} & 2 & 113 & 1619 \\ 2994 & \mathrm{C}-\mathrm{G} & 18 & 95 & 1291 \\ 3293 & \mathrm{~A}-\mathrm{E} & 9 & 105 & 1337 \\ 3305 & \mathrm{~A}-\mathrm{D} & 7 & 105 & 1044 \\ 2705 & \mathrm{~F}-\mathrm{G} & 23 & 86 & 1971 \\ 3596 & \mathrm{~A} & 1 & 115 & 1704 \\ 3129 & \mathrm{~A}-\mathrm{F} & 13 & 100 & 1393 \\ 2805 & \mathrm{E}-\mathrm{G} & 22 & 89 & 1424 \\ 2998 & \mathrm{C}-\mathrm{G} & 17 & 95 & 2234 \\ 3296 & \mathrm{~A}-\mathrm{E} & 8 & 105 & 1320 \\ 3190 & \mathrm{~A}-\mathrm{F} & 12 & 102 & 1759 \\ 3444 & \mathrm{~A}-\mathrm{C} & 3 & 110 & 2196 \\ 3022 & \mathrm{C}-\mathrm{G} & 16 & 96 & 1228 \\ 2564 & \mathrm{G} & 24 & 82 & 1049 \\ 3347 & \mathrm{~A}-\mathrm{D} & 5 & 107 & 1641 \\ 2941 & \mathrm{D}-\mathrm{G} & 20 & 94 & 1726 \\ 3201 & \mathrm{~A}-\mathrm{E} & 11 & 102 & 1566 \\ 2982 & \mathrm{C}-\mathrm{G} & 19 & 95 & 1526 \\ 3107 & \mathrm{~A}-\mathrm{F} & 14 & 99 & 1388 \\ 3206 & \mathrm{~A}-\mathrm{E} & 10 & 102 & 1462 \\ 3408 & \mathrm{~A}-\mathrm{D} & 4 & 109 & 1911 \\ 2920 & \mathrm{D}-\mathrm{G} & 21 & 93 & 1308 \\ 3055 & \mathrm{~B}-\mathrm{F} & 15 & 97 & 1512 \\ & & & & \\ 3140 & & & & 1535\end{array}$

A $22 \quad 80$

A 9105

A $20 \quad 84$

$\begin{array}{lll}\text { A } & 17 & 87\end{array}$

A $\quad 24 \quad 68$

$\begin{array}{lll}A & 3 & 128\end{array}$

A $7 \quad 111$

A $\quad 15 \quad 91$

A $14 \quad 93$

A 11146

A $18 \quad 86$

A $5 \quad 115$

A 2143

A $21 \quad 80$

A $23 \quad 68$

$\begin{array}{lll}\text { A } & 8 & 107\end{array}$

A $6 \quad 112$

A $10 \quad 102$

A $\quad 11 \quad 99$

A $\quad 16 \quad 90$

A $13 \quad 95$

A $4 \quad 124$

A $\quad 19 \quad 85$

A $\quad 12 \quad 99$ 
Table 8. Agronomic characteristics of 24 soybean genotypes grown during 1980 at four locations. (Test 1980 , A-4).

Genotype

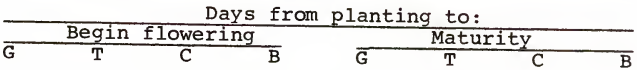

\begin{tabular}{lllllllll} 
Jupiter & 53 & 50 & 48 & 48 & 118 & 105 & 110 & 130 \\
UFV-1 & 48 & 41 & 38 & 37 & 117 & 105 & 111 & 121 \\
F75-9207 & 49 & 43 & 38 & 32 & 122 & 105 & 117 & 119 \\
F78-1219 & 45 & 41 & 34 & 36 & 116 & 102 & 105 & 121 \\
F78-1220 & 53 & 47 & 44 & 44 & 117 & 103 & 105 & 130 \\
F78-1221 & 49 & 42 & 39 & 37 & 112 & 101 & 105 & 111 \\
F78-1236 & 51 & 48 & 45 & 47 & 120 & 105 & 113 & 128 \\
F78-1240 & 51 & 48 & 46 & 45 & 118 & 103 & 109 & 128 \\
F78-1241 & 45 & 40 & 35 & 35 & 114 & 105 & 105 & 117 \\
F78-1243 & 44 & 47 & 41 & 39 & 114 & 101 & 104 & 110 \\
F78-1246 & 55 & 47 & 42 & 38 & 116 & 101 & 104 & 120 \\
F78-1247 & 50 & 47 & 41 & 42 & 114 & 101 & 105 & 115 \\
F78-1250 & 50 & 43 & 41 & 39 & 122 & 112 & 112 & 119 \\
F78-1251 & 53 & 51 & 49 & 44 & 121 & 105 & 110 & 128 \\
F78-1316 & 50 & 49 & 38 & 32 & 121 & 112 & 115 & 117 \\
F78-1331 & 51 & 46 & 40 & 39 & 121 & 105 & 111 & 117 \\
F78-1347 & 50 & 43 & 41 & 39 & 114 & 105 & 107 & 115 \\
F78-1350 & 49 & 42 & 38 & 39 & 118 & 105 & 108 & 117 \\
F78-1351 & 57 & 50 & 46 & 39 & 129 & 124 & 131 & 135 \\
F78-1373 & 51 & 50 & 44 & 39 & 129 & 124 & 133 & 130 \\
F78-1377 & 49 & 43 & 38 & 42 & 122 & 109 & 104 & 135 \\
F78-1378 & 50 & 47 & 41 & 39 & 130 & 124 & 127 & 135 \\
F78-1469 & 49 & 48 & 46 & 47 & 124 & 124 & 115 & 130 \\
F78-1541 & 44 & 40 & 34 & 32 & 119 & 103 & 104 & 122 \\
Test mean & 50 & 46 & 41 & 40 & 119 & 108 & 111 & 123 \\
F7 & & & & & & & & \\
\hline
\end{tabular}

G, T, C, and B refer to Gainesville, Tancasneque, Tapachula and Boliche respectively. 
Table 8-extended

\begin{tabular}{|c|c|c|c|c|c|c|c|c|c|}
\hline \multicolumn{4}{|c|}{$\begin{array}{c}\text { Plant height } \\
\mathrm{cm}\end{array}$} & \multicolumn{3}{|c|}{$\begin{array}{c}\text { Seed weight } \\
\mathrm{g} / 100\end{array}$} & \multicolumn{2}{|c|}{$\begin{array}{c}\text { Node } \\
\text { number }\end{array}$} & \multirow{2}{*}{$\begin{array}{c}\begin{array}{c}\text { Canopy } \\
\text { width }(\mathrm{cm})\end{array} \\
\mathrm{G}\end{array}$} \\
\hline$\overline{\mathrm{G}}$ & $\mathrm{T}$ & $C$ & $\bar{B}$ & $\bar{G}$ & $\mathrm{~T}$ & $\bar{B}$ & $\overline{\mathrm{G}}$ & $T$ & \\
\hline 70 & 74 & 84 & 59 & 14.31 & 14 & 25.3 & 13 & 12 & 50 \\
\hline 55 & 47 & 64 & 31 & 11.11 & 14 & 21.0 & 11 & 11 & 55 \\
\hline 65 & 63 & 73 & 39 & 13.45 & 12 & 22.3 & 16 & 16 & 60 \\
\hline 57 & 46 & 67 & 39 & 10.63 & 12 & 22.8 & 10 & 10 & 50 \\
\hline 80 & 64 & 79 & 56 & 15.64 & 16 & 26.1 & 13 & 11 & 60 \\
\hline 80 & 82 & 109 & 63 & 14.36 & 15 & 23.1 & 15 & 16 & 60 \\
\hline 65 & 69 & 78 & 51 & 14.50 & 15 & 24.7 & 11 & 10 & 50 \\
\hline 85 & 58 & 92 & 51 & 13.21 & 13 & 24.9 & 13 & 14 & 65 \\
\hline 77 & 69 & 103 & 54 & 13.07 & 13 & 25.1 & 16 & 16 & 60 \\
\hline 77 & 62 & 78 & 58 & 12.37 & 13 & 22.0 & 12 & 12 & 55 \\
\hline 80 & 64 & 76 & 61 & 15.11 & 13 & 26.1 & 13 & 13 & 55 \\
\hline 80 & 59 & 82 & 56 & 15.53 & 13 & 24.5 & 13 & 13 & 60 \\
\hline 90 & 86 & 121 & 64 & 14.93 & 14 & 23.9 & 16 & 17 & 60 \\
\hline 72 & 74 & 79 & 62 & 14.80 & 14 & 28.5 & 13 & 14 & 50 \\
\hline 62 & 57 & 65 & 30 & 9.35 & 12 & 16.2 & 13 & 9 & 60 \\
\hline 85 & 90 & 116 & 66 & 13.92 & 14 & 22.6 & 14 & 17 & 70 \\
\hline 87 & 81 & 114 & 55 & 11.27 & 11 & 19.1 & 14 & 17 & 60 \\
\hline 75 & 67 & 85 & 44 & 12.42 & 11 & 17.8 & 15 & 17 & 60 \\
\hline 75 & 75 & 76 & 45 & 14.52 & 15 & 21.2 & 13 & 12 & 70 \\
\hline 80 & 78 & 74 & 30 & 13.61 & 15 & 20.8 & 13 & 12 & 65 \\
\hline 65 & 72 & 86 & 37 & 13.84 & 14 & 21.4 & 13 & 13 & 60 \\
\hline 70 & 85 & 80 & 41 & 12.76 & 16 & 21.0 & 13 & 12 & 65 \\
\hline 72 & 81 & 86 & 68 & 13.19 & 13 & 20.4 & 16 & 12 & 75 \\
\hline 72 & 62 & 76 & 35 & 14.28 & 13 & 22.2 & 13 & 14 & 60 \\
\hline 74 & 69 & 85 & 50 & 13.42 & 14 & 22.6 & 13 & 13 & \\
\hline
\end{tabular}


Table 9. Mean yield of 24 soybean genotypes grown during 1978 at two locations in $\mathrm{kg} / \mathrm{ha}$, rank, and as percent of overall test mean. (Test $1978, \mathrm{~B}-1$ ). Duncan's test at .05 level.

\begin{tabular}{|c|c|c|c|c|c|c|c|c|}
\hline \multirow[b]{2}{*}{ Genotype } & \multicolumn{4}{|c|}{ Gainesville yield } & \multicolumn{4}{|c|}{ Tancasneque yield } \\
\hline & $\begin{array}{c}\text { Yield } \\
\text { in } \\
\mathrm{kg} / \mathrm{ha}\end{array}$ & + & $\begin{array}{r}\text { Rank } \\
\text { no. }\end{array}$ & $\begin{array}{c}\text { Yield } \\
\text { in } \\
\frac{8}{8}\end{array}$ & $\begin{array}{c}\text { Yield } \\
\text { in } \\
\mathrm{kg} / \mathrm{ha}\end{array}$ & + & $\begin{array}{r}\text { Rank } \\
\text { no. }\end{array}$ & $\begin{array}{c}\text { Yield } \\
\text { in } \\
\%\end{array}$ \\
\hline Jupiter & 1348 & $B-D$ & 21 & 87 & 1457 & $A-C$ & 3 & 115 \\
\hline UFV-1 & 1463 & $B-D$ & 16 & 94 & 1544 & $A-B$ & 2 & 122 \\
\hline F76-6719 & 1765 & $A-C$ & 4 & 114 & 1113 & $\mathrm{D}$ & 21 & 88 \\
\hline F 76-6724 & 1350 & $B-D$ & 20 & 87 & 1171 & C-D & 19 & 92 \\
\hline F 76-6728 & 1590 & $B-C$ & 10 & 102 & 1341 & $A-D$ & 7 & 106 \\
\hline F76-6854 & 1533 & B-D & 12 & 99 & 1210 & $C-D$ & 16 & 95 \\
\hline F76-6858 & 887 & D & 24 & 57 & 1321 & $A-D$ & 9 & 104 \\
\hline F76-6938 & 1422 & $B-D$ & 19 & 92 & 1599 & A & 1 & 126 \\
\hline F76-7000 & 1438 & $B-D$ & 18 & 93 & 1378 & $A-D$ & 5 & 109 \\
\hline F76-7087 & 2301 & A & 1 & 148 & 1043 & & 24 & 82 \\
\hline F76-7095 & 1931 & A-B & 2 & 124 & 1215 & $C-D$ & 15 & 96 \\
\hline F76-7113 & 1332 & $B-D$ & 22 & 86 & 1304 & $A-D$ & 10 & 103 \\
\hline F76-7145 & 1497 & $B-D$ & 14 & 96 & 1220 & $C-D$ & 14 & 96 \\
\hline F76-7162 & 1161 & $C-D$ & 23 & 75 & 1283 & $B-D$ & 11 & 101 \\
\hline F76-7205 & 1471 & $B-D$ & 15 & 95 & 1146 & $\bar{C}-\bar{D}$ & 20 & 90 \\
\hline F76-7215 & 1792 & $A-C$ & 3 & 115 & 1357 & $A-D$ & 6 & 107 \\
\hline F76-7295 & 1752 & $A-C$ & 6 & 113 & 1329 & $A-D$ & 8 & 105 \\
\hline F 76-7298 & 1554 & $B-C$ & 11 & 100 & 1173 & C-D & 18 & 93 \\
\hline F76-7323 & 1648 & $B-C$ & 7 & 106 & 1403 & $A-D$ & 4 & 111 \\
\hline F 76-7326 & 1526 & $B-D$ & 13 & 98 & 1085 & D & 23 & 86 \\
\hline F76-7333 & 1641 & $B-C$ & 8 & 106 & 1186 & $C-D$ & 17 & 94 \\
\hline F76-7336 & 1761 & $A-C$ & 5 & 113 & 1100 & D & 22 & 87 \\
\hline F76-7351 & 1640 & $B-C$ & 9 & 106 & 1243 & $B-D$ & 12 & 98 \\
\hline F76-7376 & 1459 & $B-D$ & 17 & 94 & 1221 & $C-D$ & 13 & 96 \\
\hline Test mean & 1553 & & & 100 & 1268 & & & 100 \\
\hline
\end{tabular}

+ means with the same letter are not significantly different at the .05 level. 
Table 10. Agronomic characteristics of 24 soybean genotypes grown during 1978 at two locations. (Test 1978, $\mathrm{B}-1)$.

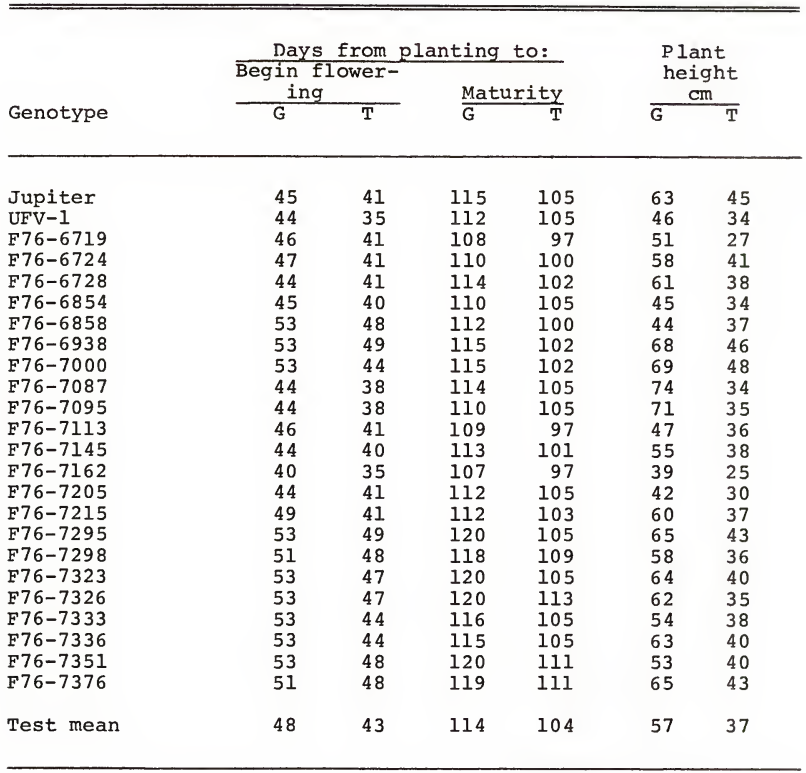

$G$ and $T$ refer to Gainesville and Tancasneque respectively. 
Table 11. Mean yield of 22 soybean genotypes grown during 1978 at two locations in $\mathrm{kg} / \mathrm{ha}$, rank, and as percent of overall test mean. (Test 1978, B-2). Duncan's test at .05 level.

\begin{tabular}{|c|c|c|c|c|c|c|c|c|}
\hline \multirow[b]{2}{*}{ Genotype } & \multicolumn{4}{|c|}{ Gainesville yield } & \multicolumn{4}{|c|}{ Tancasneque yield } \\
\hline & $\begin{array}{c}\text { Yield } \\
\text { in } \\
\mathrm{kg} / \mathrm{ha}\end{array}$ & + & $\begin{array}{c}\text { Rank } \\
\text { no. }\end{array}$ & $\begin{array}{c}\text { Yield } \\
\text { in } \\
\frac{8}{8}\end{array}$ & $\begin{array}{c}\text { Yield } \\
\text { in } \\
\mathrm{kg} / \mathrm{ha}\end{array}$ & + & $\begin{array}{r}\text { Rank } \\
\text { no. }\end{array}$ & $\begin{array}{c}\text { Yield } \\
\text { in } \\
8\end{array}$ \\
\hline Jupiter & 1787 & $A-C$ & 16 & 104 & 1661 & $\mathrm{~A}-\mathrm{B}$ & 2 & 128 \\
\hline UFV-1 & 1542 & $A-C$ & 17 & 90 & 1390 & $A-D$ & 7 & 108 \\
\hline D73-9360 & 1887 & $\mathrm{~A}-\mathrm{C}$ & 8 & 110 & 993 & $\mathrm{D}-\mathrm{E}$ & 21 & 77 \\
\hline F74-2716 & 1609 & $A-C$ & 16 & 94 & 1326 & $\bar{A}-\bar{D}$ & 11 & 103 \\
\hline F74-3491 & 1499 & $\mathrm{~B}-\mathrm{C}$ & 18 & 87 & 1110 & $B-E$ & 19 & 86 \\
\hline F75-7093 & 1914 & $A-C$ & 7 & 111 & 782 & $\mathrm{E}$ & 22 & 60 \\
\hline F75-9207 & 2051 & A-B & 2 & 119 & 1549 & $\bar{A}-\mathrm{C}$ & 4 & 120 \\
\hline F75-9209 & 1968 & $A-C$ & 5 & 114 & 1329 & $A-D$ & 10 & 103 \\
\hline F76-6554 & 698 & D & 22 & 41 & 1134 & $B-E$ & 17 & 88 \\
\hline F76-6570 & 1432 & $B-C$ & 19 & 83 & 1112 & $B-E$ & 18 & 86 \\
\hline F76-9835 & 1356 & C & 21 & 79 & 1695 & A & 1 & 131 \\
\hline F76-9967 & 1692 & $A-C$ & 15 & 98 & 1304 & $A-E$ & 12 & 101 \\
\hline F76-0002 & 1694 & $A-C$ & 14 & 98 & 1150 & $A-E$ & 16 & 89 \\
\hline F76-0007 & 2183 & A & 1 & 127 & 1154 & $A-E$ & 15 & 89 \\
\hline F76-6875 & 1848 & $A-C$ & 9 & 107 & 1330 & $A-D$ & 9 & 103 \\
\hline F76-6883 & 1769 & $A-C$ & 13 & 103 & 1604 & $A-B$ & 3 & 124 \\
\hline F76-6884 & 2024 & $A-C$ & 3 & 118 & 1300 & $A-E$ & 13 & 101 \\
\hline F76-6918 & 1969 & $A-C$ & 4 & 114 & 1178 & $A-E$ & 14 & 91 \\
\hline F76-6928 & 1363 & C & 20 & 79 & 1495 & $A-D$ & 5 & 116 \\
\hline F 76-7233 & 1835 & $A-C$ & 10 & 107 & 1435 & $A-D$ & 6 & 111 \\
\hline F76-7236 & 192.3 & $A-C$ & 6 & 112 & 1366 & $A-D$ & 8 & 106 \\
\hline F76-7452 & 1796 & $A-C$ & 11 & 104 & 1045 & $\mathrm{C}-\mathrm{E}$ & 20 & 81 \\
\hline Test mean & 1720 & & & 100 & 1293 & & & 100 \\
\hline
\end{tabular}

+ means with the same letter are not significantly different at the .05 level. 
Table 12. Agronomic characteristics of 22 soybean genotypes grown during 1978 at two locations. (Test 1978, $\mathrm{B}-2)$.

\begin{tabular}{|c|c|c|c|c|c|c|}
\hline \multirow[b]{2}{*}{ Genotype } & \multicolumn{2}{|c|}{$\begin{array}{l}\text { Days from } p \\
\text { Begin flower- } \\
\text { ing }\end{array}$} & nting & \multirow{2}{*}{$\frac{\text { ity }}{\mathrm{T}}$} & \multicolumn{2}{|c|}{$\begin{array}{l}\text { Plant } \\
\text { height } \\
\mathrm{cm} \\
\end{array}$} \\
\hline & $G$ & $\bar{T}$ & $\overline{\mathrm{G}}$ & & $\overline{\mathrm{G}}$ & $\bar{T}$ \\
\hline $\begin{array}{l}\text { Jupiter } \\
\text { UFV-1 } \\
\text { D73-9360 } \\
\text { F74-2716 } \\
\text { F74-3491 } \\
\text { F75-7093 } \\
\text { F75-9207 } \\
\text { F75-9209 } \\
\text { F76-6554 } \\
\text { F76-6570 } \\
\text { F76-9835 } \\
\text { F76-9967 } \\
\text { F76-0002 } \\
\text { F76-0007 } \\
\text { F76-6875 } \\
\text { F76-6883 } \\
\text { F76-6884 } \\
\text { F76-6918 } \\
\text { F76-6928 } \\
\text { F76-7233 } \\
\text { F76-7236 } \\
\text { F76-7452 }\end{array}$ & $\begin{array}{l}47 \\
46 \\
41 \\
39 \\
40 \\
37 \\
50 \\
48 \\
55 \\
53 \\
43 \\
51 \\
47 \\
46 \\
53 \\
46 \\
50 \\
47 \\
54 \\
51 \\
52 \\
37\end{array}$ & $\begin{array}{l}43 \\
35 \\
37 \\
34 \\
34 \\
34 \\
41 \\
39 \\
48 \\
48 \\
36 \\
41 \\
41 \\
41 \\
49 \\
39 \\
48 \\
41 \\
49 \\
47 \\
47 \\
34\end{array}$ & $\begin{array}{l}115 \\
112 \\
112 \\
111 \\
108 \\
101 \\
116 \\
112 \\
112 \\
113 \\
107 \\
118 \\
106 \\
107 \\
119 \\
117 \\
120 \\
117 \\
115 \\
117 \\
117 \\
104\end{array}$ & $\begin{array}{r}105 \\
105 \\
103 \\
105 \\
97 \\
97 \\
105 \\
105 \\
109 \\
109 \\
105 \\
105 \\
97 \\
97 \\
109 \\
109 \\
105 \\
105 \\
101 \\
107 \\
105 \\
97\end{array}$ & $\begin{array}{l}68 \\
57 \\
47 \\
45 \\
45 \\
62 \\
75 \\
77 \\
60 \\
64 \\
50 \\
63 \\
64 \\
55 \\
68 \\
61 \\
70 \\
73 \\
82 \\
67 \\
69 \\
53\end{array}$ & $\begin{array}{l}54 \\
36 \\
28 \\
28 \\
30 \\
30 \\
40 \\
40 \\
20 \\
27 \\
40 \\
41 \\
37 \\
33 \\
47 \\
41 \\
43 \\
40 \\
59 \\
36 \\
34 \\
26\end{array}$ \\
\hline Test mean & 47 & 41 & 112 & 104 & 62 & 37 \\
\hline
\end{tabular}

$G$ and $T$ refer to Gainesville and Tancasneque respectively. 
Table 13. Mean yield of 24 soybean genotypes grown during 1979 at three locations in $\mathrm{kg} / \mathrm{ha}$, rank and as percent of overall test mean. (Test 1979, B-3). Duncan's test at .05 level.

\begin{tabular}{|c|c|c|c|c|c|c|c|c|}
\hline \multirow[b]{2}{*}{ Genotype } & \multicolumn{4}{|c|}{ Gainesville yield } & \multicolumn{4}{|c|}{ Tancasneque yield } \\
\hline & $\begin{array}{c}\text { Yield } \\
\text { in } \\
\mathrm{kg} / \mathrm{ha}\end{array}$ & + & $\begin{array}{c}\text { Rank } \\
\text { no. }\end{array}$ & $\begin{array}{c}\text { Yiela } \\
\text { in } \\
\frac{8}{}\end{array}$ & $\begin{array}{c}\text { Yield } \\
\text { in } \\
\mathrm{kg} / \mathrm{ha}\end{array}$ & + & $\begin{array}{c}\text { Rank } \\
\text { no. }\end{array}$ & $\begin{array}{c}\text { Yield } \\
\text { in } \\
\%\end{array}$ \\
\hline $\begin{array}{l}\text { Jupiter } \\
\text { UFV-1 } \\
\text { F75-9207 } \\
\text { F75-9209 } \\
\text { F75-7093 } \\
\text { F76-0007 } \\
\text { F76-6719 } \\
\text { F76-6728 } \\
\text { F76-6883 } \\
\text { F76-6884 } \\
\text { F76-6918 } \\
\text { F76-6928 } \\
\text { F76-6938 } \\
\text { F76-7000 } \\
\text { F76-7087 } \\
\text { F76-7095 } \\
\text { F76-7113 } \\
\text { F76-7215 } \\
\text { F76-7233 } \\
\text { F76-7236 } \\
\text { F76-7295 } \\
\text { F76-7323 } \\
\text { F76-7351 } \\
\text { F76-9835 }\end{array}$ & $\begin{array}{l}1602 \\
1775 \\
1634 \\
1784 \\
1855 \\
1085 \\
1622 \\
1455 \\
1260 \\
1770 \\
1702 \\
1542 \\
1370 \\
1675 \\
1723 \\
1931 \\
1616 \\
1463 \\
1551 \\
1839 \\
1490 \\
1607 \\
1540 \\
1811\end{array}$ & $\begin{array}{l}\text { A } \\
\text { A } \\
\text { A } \\
A \\
A \\
A \\
A \\
A \\
A \\
A \\
A \\
A \\
A \\
A \\
A \\
A \\
A \\
A \\
A \\
A \\
A \\
A \\
A \\
A\end{array}$ & $\begin{array}{r}15 \\
6 \\
2 \\
11 \\
5 \\
24 \\
12 \\
21 \\
23 \\
7 \\
9 \\
17 \\
22 \\
10 \\
8 \\
1 \\
13 \\
20 \\
16 \\
3 \\
19 \\
14 \\
18 \\
4\end{array}$ & $\begin{array}{r}99 \\
110 \\
101 \\
111 \\
115 \\
67 \\
101 \\
90 \\
78 \\
110 \\
106 \\
96 \\
85 \\
104 \\
107 \\
120 \\
100 \\
91 \\
96 \\
114 \\
92 \\
100 \\
95 \\
112\end{array}$ & $\begin{array}{l}1857 \\
1865 \\
1437 \\
1273 \\
1251 \\
1388 \\
1576 \\
1355 \\
1411 \\
1889 \\
1446 \\
1583 \\
1758 \\
1649 \\
1288 \\
1488 \\
1426 \\
1198 \\
2164 \\
1252 \\
1592 \\
1315 \\
1672 \\
1769\end{array}$ & $\begin{array}{l}A-C \\
A-B \\
D-H \\
F-H \\
G-H \\
D-H \\
B-H \\
E-H \\
D-H \\
A-B \\
D-H \\
B-G \\
B-D \\
B-F \\
F-H \\
C-H \\
D-H \\
H \\
A \\
G-H \\
B-G \\
E-H \\
B-E \\
B-D\end{array}$ & $\begin{array}{r}4 \\
3 \\
14 \\
21 \\
23 \\
17 \\
11 \\
18 \\
16 \\
2 \\
13 \\
10 \\
6 \\
8 \\
20 \\
12 \\
15 \\
24 \\
1 \\
22 \\
9 \\
19 \\
7 \\
5\end{array}$ & $\begin{array}{r}121 \\
121 \\
93 \\
83 \\
81 \\
90 \\
102 \\
88 \\
92 \\
123 \\
94 \\
103 \\
114 \\
107 \\
84 \\
97 \\
93 \\
78 \\
141 \\
81 \\
104 \\
86 \\
109 \\
115\end{array}$ \\
\hline & 1613 & & & 100 & 1538 & & & 100 \\
\hline
\end{tabular}

+ means with the same letter are not significantly different at the .05 level. 
Table 13-extended

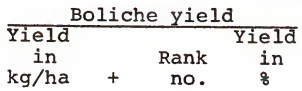

$\begin{array}{rlrr}2598 & \text { B-D } & 7 & 115 \\ 2582 & \text { B-D } & 8 & 114 \\ 1290 & \text { I } & 24 & 57 \\ 1378 & \text { H-I } & 23 & 61 \\ 2037 & \text { D-G } & 16 & 90 \\ 1977 & \text { E-G } & 17 & 88 \\ 2389 & \text { B-F } & 11 & 106 \\ 1830 & \text { F-H } & 21 & 81 \\ 1846 & \text { F-H } & 19 & 82 \\ 2790 & \text { A-B } & 2 & 124 \\ 2519 & \text { B-E } & 10 & 112 \\ 2693 & \text { A-C } & 6 & 119 \\ 2699 & \text { A-C } & 5 & 119 \\ 2261 & \text { B-F } & 14 & 100 \\ 1875 & \text { F-H } & 18 & 83 \\ 2309 & \text { B-F } & 12 & 102 \\ 1839 & \text { F-H } & 20 & 81 \\ 1585 & \text { G-I } & 22 & 70 \\ 3170 & \text { A } & 1 & 140 \\ 2704 & \text { A-C } & 4 & 120 \\ 2278 & \text { B-F } & 13 & 101 \\ 2784 & \text { A-B } & 3 & 123 \\ 2580 & \text { B-D } & 9 & 114 \\ 2199 & \text { C-F } & 15 & 97 \\ & & & \\ 2259 & & & 100\end{array}$


Nก⿻

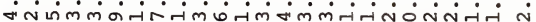
NNNNNANANNNNNNNNNNNNNNNN N

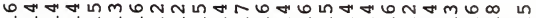

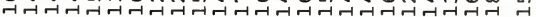

Nmbo nmषNN I ก

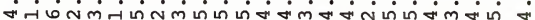

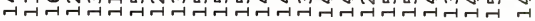

œ

$\left.\left.\right|_{0} ^{+}\right|_{0} ^{\infty}$

HNHANN⿻上丨

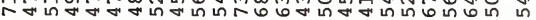
ำ

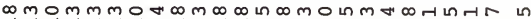

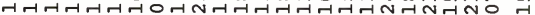

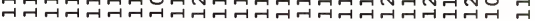

*

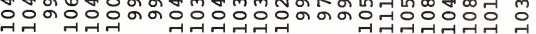

- 1 o

내

$+$

(

岃

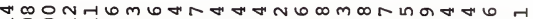

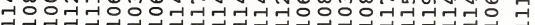

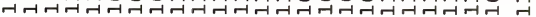

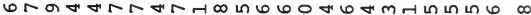

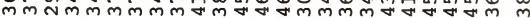

ต $N$ แก ザ

のm

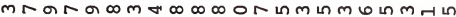

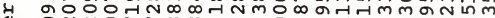

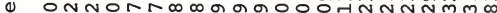

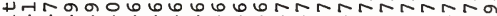

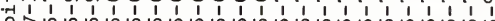

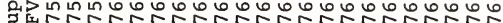

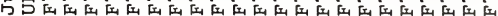


Table 15. Mean yield of 24 soybean genotypes grown during 1980 at four locations in $\mathrm{kg} / \mathrm{ha}$, rank, and as percent of overall test mean. (Test $1980, \mathrm{~B}-4$ ). Duncan's test at .05 level.

\begin{tabular}{|c|c|c|c|c|c|c|c|c|}
\hline \multirow[b]{2}{*}{ Genotype } & \multicolumn{4}{|c|}{ Gainesville yield } & \multicolumn{4}{|c|}{ Tancasneque yield } \\
\hline & $\begin{array}{c}\text { Yield } \\
\text { in } \\
\mathrm{kg} / \mathrm{ha}\end{array}$ & + & $\begin{array}{c}\text { Rank } \\
\text { no. }\end{array}$ & $\begin{array}{c}\text { Yield } \\
\text { in } \\
8\end{array}$ & $\begin{array}{l}\text { Yield } \\
\text { in } \\
\mathrm{kg} / \mathrm{ha}\end{array}$ & + & $\begin{array}{c}\text { Rank } \\
\text { no. }\end{array}$ & $\begin{array}{c}\text { Yield } \\
\text { in } \\
8\end{array}$ \\
\hline Jupiter & 1859 & A & 17 & 96 & 2274 & $A-D$ & 11 & 104 \\
\hline UFV-1 & 1973 & A & 10 & 102 & 2460 & $A-B$ & 2 & 113 \\
\hline F75-9207 & 1902 & A & 14 & 98 & 1992 & $\mathrm{~B}-\mathrm{F}$ & 19 & 91 \\
\hline F75-9209 & 1830 & A & 18 & 94 & 1875 & $\mathrm{C}-\mathrm{F}$ & 21 & 86 \\
\hline F75-7093 & 2042 & $\mathrm{~A}$ & 7 & 105 & 1632 & $\mathrm{~F}$ & 24 & 75 \\
\hline F76-0007 & 2105 & A & 5 & 108 & 2405 & $A-B$ & 5 & 110 \\
\hline F 76-6719 & 1727 & A & 23 & 89 & 2310 & $A-C$ & 10 & 106 \\
\hline F76-6728 & 1932 & A & 12 & 99 & 2056 & $B-F$ & 18 & 94 \\
\hline F76-6883 & 1867 & A & 16 & 96 & 2435 & $A-B$ & 4 & 112 \\
\hline F76-6884 & 1975 & A & 9 & 102 & 2138 & $B-E$ & 13 & 98 \\
\hline F76-6918 & 1783 & A & 21 & 92 & 2185 & $B-E$ & 12 & 100 \\
\hline F76-6928 & 1936 & A & 11 & 100 & 1982 & B-F & 20 & 91 \\
\hline F76-6938 & 2039 & A & 8 & 105 & 2383 & $A-B$ & 7 & 109 \\
\hline F76-7000 & 1781 & A & 22 & 92 & 2762 & A & 1 & 127 \\
\hline F 76-7987 & 2140 & A & 3 & 110 & 2135 & $B-E$ & 14 & 98 \\
\hline F76-7095 & 1905 & A & 13 & 98 & 2116 & $B-F$ & 16 & 97 \\
\hline F76-7113 & 1825 & $\mathrm{~A}$ & 19 & 94 & 2446 & $\mathrm{~A}-\mathrm{B}$ & 3 & 112 \\
\hline F76-7215 & 2221 & $\mathrm{~A}$ & 2 & 114 & 2122 & $B-F$ & 15 & 97 \\
\hline F76-7233 & 1798 & A & 20 & 93 & 2396 & $A-B$ & 6 & 110 \\
\hline F76-7236 & 2229 & A & 1 & 115 & 2078 & $B-F$ & 17 & 95 \\
\hline F76-7295 & 2055 & A & 6 & 106 & 1784 & $D-F$ & 22 & 82 \\
\hline F76-7323 & 1882 & A & 15 & 97 & 2341 & $\mathrm{~A}-\mathrm{C}$ & 8 & 107 \\
\hline F76-7351 & 1690 & $\mathrm{~A}$ & 24 & 87 & 1738 & $E-F$ & 23 & 80 \\
\hline \multirow[t]{2}{*}{ F76-9835 } & 2136 & A & 4 & 110 & 2332 & $\mathrm{~A}-\mathrm{C}$ & 9 & 107 \\
\hline & 1943 & & & 100 & 2182 & & & 100 \\
\hline
\end{tabular}

+ means with the same letter are not significantly different at the .05 level. 
Table 15-extended

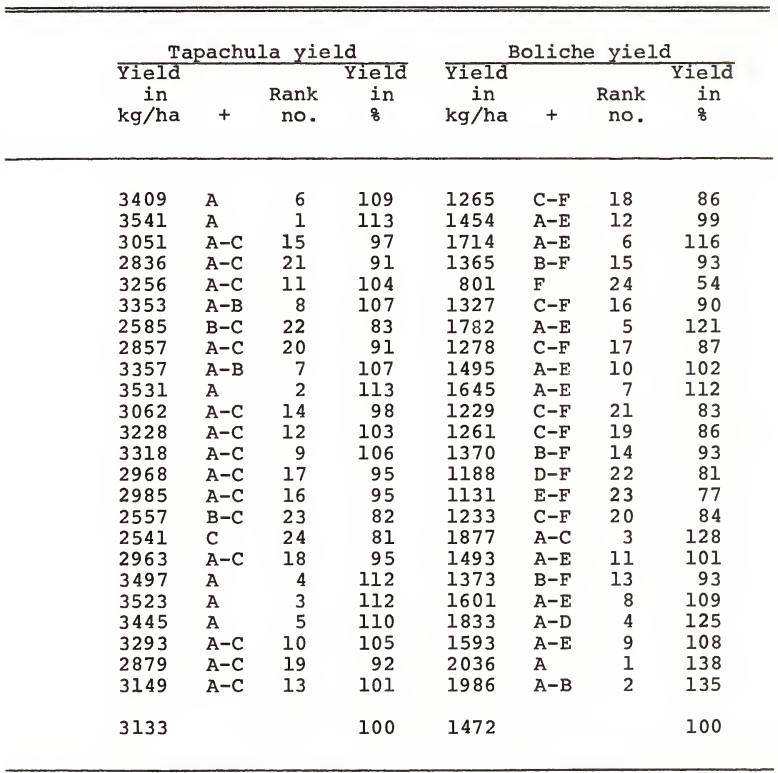


Table 16. Agronomic characteristics of 24 soybean genotypes grown during 1980 at four locations. (Test 1980, B-4).

Days from planting to:

Genotype

$\frac{\text { Begin flowering }}{\mathrm{G}} \mathrm{C}$

$\frac{\text { Maturity }}{\mathrm{G} \quad \mathrm{C}} \mathrm{B}$

\begin{tabular}{lllllllll} 
Jupiter & 53 & 53 & 48 & 48 & 118 & 118 & 110 & 122 \\
UFV-1 & 49 & 43 & 38 & 36 & 117 & 115 & 112 & 113 \\
F75-9207 & 49 & 45 & 37 & 31 & 122 & 118 & 117 & 104 \\
F75-9209 & 50 & 43 & 36 & 31 & 122 & 118 & 117 & 104 \\
F75-7093 & 42 & 40 & 31 & 31 & 107 & 106 & 98 & 104 \\
F76-0007 & 47 & 42 & 39 & 34 & 114 & 112 & 104 & 104 \\
F76-6719 & 49 & 43 & 39 & 33 & 110 & 112 & 103 & 104 \\
F76-6728 & 46 & 42 & 34 & 31 & 121 & 115 & 110 & 104 \\
F76-6883 & 49 & 45 & 41 & 34 & 124 & 118 & 112 & 124 \\
F76-6884 & 51 & 47 & 44 & 41 & 122 & 118 & 115 & 129 \\
F76-6918 & 48 & 46 & 42 & 33 & 121 & 118 & 112 & 134 \\
F76-6928 & 55 & 52 & 48 & 47 & 118 & 112 & 107 & 118 \\
F76-6938 & 53 & 52 & 48 & 48 & 118 & 118 & 105 & 122 \\
F76-7000 & 49 & 52 & 48 & 48 & 120 & 118 & 109 & 124 \\
F76-7087 & 46 & 41 & 33 & 31 & 114 & 112 & 104 & 104 \\
F76-7095 & 46 & 42 & 33 & 31 & 118 & 115 & 102 & 104 \\
F76-7113 & 49 & 44 & 40 & 34 & 109 & 112 & 103 & 104 \\
F76-7215 & 50 & 45 & 36 & 31 & 121 & 118 & 114 & 104 \\
F76-7233 & 53 & 48 & 43 & 43 & 126 & 118 & 112 & 129 \\
F76-7236 & 51 & 47 & 42 & 40 & 122 & 115 & 115 & 129 \\
F76-7295 & 54 & 52 & 48 & 47 & 121 & 118 & 112 & 124 \\
F76-7323 & 56 & 51 & 47 & 47 & 120 & 118 & 106 & 127 \\
F76-7351 & 56 & 51 & 47 & 43 & 126 & 118 & 117 & 122 \\
F76-9835 & 45 & 41 & 34 & 31 & 113 & 118 & 105 & 106 \\
Mean & 50 & 46 & 41 & 38 & 118 & 116 & 109 & 115 \\
& & & & & & & & \\
\hline
\end{tabular}

G, T, C and B refer to Gainesville, Tancasneque, Tapachula and Boliche respectively. 
Table 16-extended

\begin{tabular}{|c|c|c|c|c|c|c|c|c|c|}
\hline \multicolumn{4}{|c|}{$\begin{array}{c}\text { Plant height } \\
\mathrm{cm}\end{array}$} & \multicolumn{3}{|c|}{$\begin{array}{c}\text { Seed weight } \\
\mathrm{g} / 100\end{array}$} & \multicolumn{3}{|c|}{ Node number } \\
\hline$\overline{\mathrm{G}}$ & $\mathrm{T}$ & $\mathrm{C}$ & $\bar{B}$ & $\overline{\mathrm{G}}$ & $\mathrm{T}$ & $\bar{B}$ & $\mathrm{G}$ & $T$ & $\bar{C}$ \\
\hline $\begin{array}{l}74 \\
55 \\
80 \\
84 \\
65 \\
57 \\
57 \\
80 \\
70 \\
77 \\
90 \\
97 \\
77 \\
75 \\
72 \\
87 \\
60 \\
84 \\
72 \\
77 \\
77 \\
77 \\
75 \\
64\end{array}$ & $\begin{array}{l}83 \\
70 \\
70 \\
75 \\
64 \\
70 \\
73 \\
81 \\
76 \\
85 \\
96 \\
86 \\
81 \\
84 \\
71 \\
74 \\
75 \\
77 \\
83 \\
87 \\
82 \\
79 \\
96 \\
73\end{array}$ & $\begin{array}{l}81 \\
60 \\
64 \\
71 \\
56 \\
61 \\
59 \\
72 \\
76 \\
74 \\
93 \\
91 \\
72 \\
79 \\
65 \\
65 \\
65 \\
73 \\
72 \\
77 \\
79 \\
85 \\
86 \\
73\end{array}$ & $\begin{array}{l}62 \\
28 \\
31 \\
29 \\
25 \\
27 \\
34 \\
26 \\
45 \\
61 \\
52 \\
62 \\
62 \\
51 \\
25 \\
29 \\
37 \\
25 \\
33 \\
46 \\
57 \\
51 \\
57 \\
32\end{array}$ & $\begin{array}{l}13.95 \\
10.71 \\
12.24 \\
12.52 \\
16.49 \\
11.56 \\
13.87 \\
12.29 \\
13.13 \\
15.01 \\
14.68 \\
15.58 \\
14.54 \\
13.64 \\
13.70 \\
13.88 \\
13.98 \\
12.44 \\
14.36 \\
14.66 \\
15.26 \\
14.33 \\
14.52 \\
14.23\end{array}$ & $\begin{array}{l}17 \\
15 \\
14 \\
16 \\
17 \\
14 \\
16 \\
13 \\
15 \\
18 \\
16 \\
16 \\
16 \\
16 \\
16 \\
16 \\
17 \\
14 \\
14 \\
14 \\
16 \\
16 \\
14 \\
17\end{array}$ & $\begin{array}{l}24.6 \\
20.0 \\
20.0 \\
20.5 \\
23.6 \\
16.4 \\
21.4 \\
17.2 \\
22.2 \\
21.9 \\
23.9 \\
22.1 \\
25.8 \\
26.3 \\
20.3 \\
20.4 \\
21.3 \\
19.1 \\
22.4 \\
22.2 \\
22.9 \\
21.5 \\
21.3 \\
22.1\end{array}$ & $\begin{array}{l}12 \\
11 \\
17 \\
16 \\
12 \\
12 \\
14 \\
16 \\
13 \\
13 \\
14 \\
14 \\
13 \\
12 \\
15 \\
15 \\
13 \\
17 \\
15 \\
15 \\
16 \\
13 \\
16 \\
11\end{array}$ & $\begin{array}{r}13 \\
12 \\
16 \\
16 \\
8 \\
13 \\
14 \\
17 \\
14 \\
12 \\
17 \\
14 \\
13 \\
13 \\
16 \\
16 \\
14 \\
17 \\
17 \\
15 \\
18 \\
13 \\
20 \\
12\end{array}$ & $\begin{array}{l}13 \\
12 \\
14 \\
13 \\
12 \\
13 \\
13 \\
14 \\
13 \\
12 \\
16 \\
14 \\
13 \\
13 \\
13 \\
13 \\
12 \\
14 \\
15 \\
14 \\
16 \\
13 \\
20 \\
12\end{array}$ \\
\hline 74 & 79 & 73 & 41 & 14.00 & 15 & 21.6 & 14 & 15 & 14 \\
\hline
\end{tabular}




\section{LITERATURE CITED}

1. Anonymous. 1980. INTSOY research highlights: seed pathology. International Soybean Program. INTSOY Newsletter. No. 23. Univ. of Illinois, Urbana-Champaign.

2. Baihaki, A., R. E. Stucker, and J. W. Lambert. 1976. Association of genotype $\mathrm{X}$ environment interactions with performance level of soybean lines in preliminary yield tests. Crop Sci. 16:718-721.

3. Barrios, A. G. 1961. Comportamiento de 35 variedades de soya [Glycine max (L) Merr.] en Venezuela. Agron. Trop. 11:131-135.

4. and S. Ortega. 1968. Contribucion al estudio del comportamiento de variedades de soya en Venezuela. Agron. Trop. 2:301-319.

5. Basnet, B., E. L. Moder, and C. D. Nickell. 1974. Influence of altitude on seed yield and other characters of soybean differing in maturity in Sikkim (Himalayan Kingdom). Agron. J. 66:531-533.

6. Beard, H. B., J. C. Gilbert, and T. Sekioka. 1980. Seasonal variation in the performance of soybean in Hawaii. Crop Sci. 20:163-165.

7. Brim, C. A. 1973. Quantitative genetics and breeding. In B. E. Caldwell (Ed.), Soybean: Improvement, production, and uses. Agronomy 16:155-186. Am. Soc. Agron., Madison, Wis.

8. Byth, D. E., B. E. Caldwell, and C. R. Weber. 1969a. Specific and non-specific index selection in soybean, Glycine $\max$ (L) Merrill. Crop Sci. 9:702-705.

9. C. R. Weber, and B. E. Caldwell. 1969b. Correlated truncation selection for yield in soybean. Crop Sci. 9:699-702.

10. Camacho, L. H., G. Bastidas, D. Salazar, and D. Cardenas. 1974. Potencial productivo de diferentes genotipos de soya [Glycine max (L) Merr.] en condiciones de ambiente tropical. Revista I.C.A. Instituto Colombiano Agropecuario. Vol IX. 3:353-360. 
11. Comstock, R. E., and R. H. Moll. 1963. Genotypeenvironment interactions. In W. D. Hanson and H. F. Robinson (Eds.), Statistical genetics and plant breeding. Pub. 982 Nat'l Acad. Sci. Nat'l. Res. Council. Washington, D.C., pp. 164-194.

12. De la Paz, G. S., O. J. M. Tijerina, and M. A. Pena del Rio. 1979. Informe de actividades desarrolladas por el equipo multidisciplinario de soya durante el ciclo agricola 1978-1979. Campo Agricola Experimental, Las Huastecas. CIAT. INIA. SARH. Mexico.

13. Eberhart, S. A., and W. A. Russell. 1966. Stability parameters for comparing varieties. Crop Sci. $6: 36-40$.

14. Frey, K. J., and U. Maldonado. 1967. Relative productivity of homogeneous and heterogeneous oat cultivars in optimum and suboptimum environments. Crop Sci. 7:532-535.

15. Hanson, W. D., R. C. Leffel, and H. W. Johnson. 1962. Visual discrimination for yield among soybean phenotypes. Crop Sci. 2:93-96.

16. Hartwig, E. E. 1970. Growth and reproductive characteristics of soybean [GIycine $\max$ (L) Merr.] grown under short-day conditions. Trop. Sci. 12:47-53.

17. 1973. Varietal development. In B. E. Caldwell (Ed.), Soybean: Improvement, production, and uses. Agronomy 16:187-210. Am. Soc. Agron., Madison, Wis.

18. Hinson, K., and R. I. Smith. 1967. Varieties. In Kuell Hinson et al., Soybean in Florida. Agric. Exp. Stn. Bull. 716 .

19. 1972. Jupiter: A new soybean variety for tropical latitudes. Florida, Agric. Exp. Stn. Cir. s-217.

20. and E. E. Hartwig. 1977. Soybean in the tropics. F. A. O. Plant production and protection. Paper No. 4. Rome, Italy.

21. Judy, W. H., and H. J. Hill. 1979. International soybean variety experiment. Fifth report of results. INTSOY series No. 19. Univ. of Illinois, UrbanaChampaign. 
22. Kaw, R. N., and P. M. Menon. 1972. Association between yield and components in soybean. Indian J. Genet. Plant Breed. 32:276-280.

23. Kretschmer, A. E., Jr. 1967. The use of tropical legumes in Florida. Soil and Crop Sci. Soc. Fla. Proc. 27:358-366.

24. Kwon, S. H., and J. H. Torrie. 1964. Visual discrimination for yield in two soybean populations. Crop Sci. $4: 287-290$.

25. LeClerg, E. L., W. H. Leonard, and A. G. Clark. 1962. Field plot technique. Second Edition. Burgess Publishing Company. Minneapolis, Minn.

26. Liang, G. H. L., E. G. Heyne, and T. L. Walter. 1966. Estimates of variety $\mathrm{x}$ environmental interactions in yield tests of three small grains and their significance on the breeding programs. Crop Sci. $6: 135-139$.

27. Marquez, S. F. 1976. El problema de la interaccion genetico-ambiental en genotecnia vegetal. Ediciones Patena. Universidad Autonoma Chapingo. Mexico.

28. Oka, H. I. 1975. Breeding for wide adaptability. In T. Matsuo (Ed.), Adaptability in plants with special reference to crop yield. University of Tokyo (IBP Synthesis, 6).

29. Perez, G. P., and O. J. M. Tijerina. 1976. Jupiter: Variedad de soya para el sur de Tamaulipas. INIA., SAG. Mexico. Folleto de divulgacion No. 62.

30. Saxena, M. C., and R. K. Pandey. 1971. Characteristics and performance of some promising varieties of soybean [Glycine $\max$ (L) Merr.] at Pantnagar. Indian J. Agric. Sci. 4:355-360.

31. Schapaugh, W. T., Jr., and J. R. Wilcox. 1980. Relationship between harvest indices and other plant characteristics in soybean. Crop Sci. 20:529-533.

32. Schutz, W. M., and R. L. Bernard. 1967. Genotype X environment interactions in the regional testing of soybean strains. Crop Sci. 7:125-130.

33. Stuber, C. W., W. P. Williams, and R. H. Moll. 1973. Epistasis in maize (Zea mays L.): III significance in prediction of hybrid performance. Crop Sci. $13: 195-200$. 
34. Teixeira, M. G. 1977. Effects of day length on associations between seed yield and developmental traits in soybean [GIycine max (L) Merrill). M.S. thesis, University of Florida, Gainesville, Fla.

35. Whigham, D. K. 1975. International soybean variety experiment. First report of results. INTSOY series No. 8. Univ. of Illinois, Urbana-Champaign.

36. - 1976. International soybean variety experiment. Second report of results. INTSOY series No. 11. Univ. of Illinois, Urbana-Champaign.

37. , H. C. Minor, and S. G. Cramer. 1978. Effects of environment and managements on soybean performance in the tropics. Agron. J. 70:587-592. 


\section{BIOGRAPHICAL SKETCH}

Ponciano Perez Garcia was born November 19, 1945, in H. Matamoros, state of Tamaulipas, Mexico. He completed high school at Instituto Laurens, in 1963, at Monterrey, state of Nuevo Leon. From September 1963 to June 1968, he attended the Universidad de Nuevo Leon, and received the degree of Ingeniero Agronomo in June 1970. From September 1971 to September 1973, he studied in the Colegio de Postgraduados, Chapingo, state of Mexico, and received the degree of Maestro en Ciencias. In February 1963, he was appointed researchplant breeder by the Instituto Nacional de Investigaciones Agricolas (INIA) and worked in breeding of legume crops at Rio Bravo, Tamaulipas (1969-1971), and Tampico, Tamaulipas (1973-1975) and Chapingo, Mexico (1975-1977). In September 1977, he was granted a scholarship by Consejo Nacional de Ciencia y Tecnologia (CONACYT) to conduct graduate studies at the University of Florida. 
I certify that I have read this study and that in my opinion it conforms to acceptable standards of scholarly presentation and is fully adequate, in scope and quality, as a dissertation for the degree of Doctor of Philosophy.

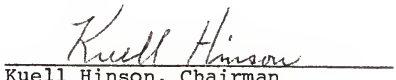

Kuell Hinson, Chairman

Professor of Agronomy

I certify that I have read this study and that in my opinion it conforms to acceptable standards of scholarly presentation and is fully adequate, in scope and quality, as a dissertation for the degree of Doctor of Philosophy.

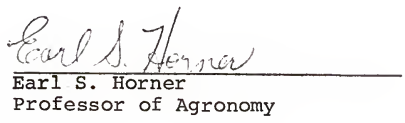

I certify that I have read this study and that in my opinion it conforms to acceptable standards of scholarly presentation and is fully adequate, in scope and quality, as a dissertation for the degree of Doctor of Philosophy.

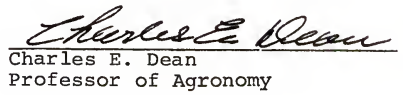


I certify that I have read this study and that in my opinion it conforms to acceptable standards of scholarly presentation and is fully adequate, in scope and quality, as a dissertation for the degree of Doctor of Philosophy.

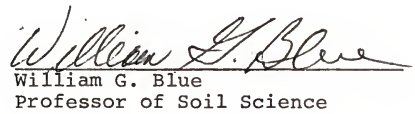

I certify that I have read this study and that in my opinion it conforms to acceptable standards of scholarly presentation and is fully adequate, in scope and quality, as a dissertation for the degree of Doctor of Philosophy.

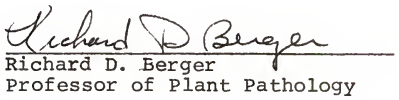

This dissertation was submitted to the Graduate Faculty of the College of Agriculture and to the Graduate Council, and was accepted as partial fulfillment of the requirements for the degree of Doctor of Philosophy.

June 1981

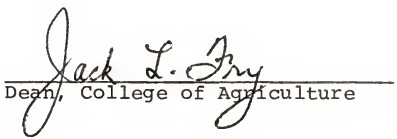

Dean for Graduate Studies and Research 